\title{
$\frac{30 \%=81}{12=-3 y)} \quad$ MASTER \\ 2
}

\section{SOLAR ENERGY SYSTEM}

PERFORMANCE EVALUATION

SUMMERWOOD ASSOCIATES, HOUSE M

Old Saybrook, Connecticut

June 1980 through May 1981

DHW SH
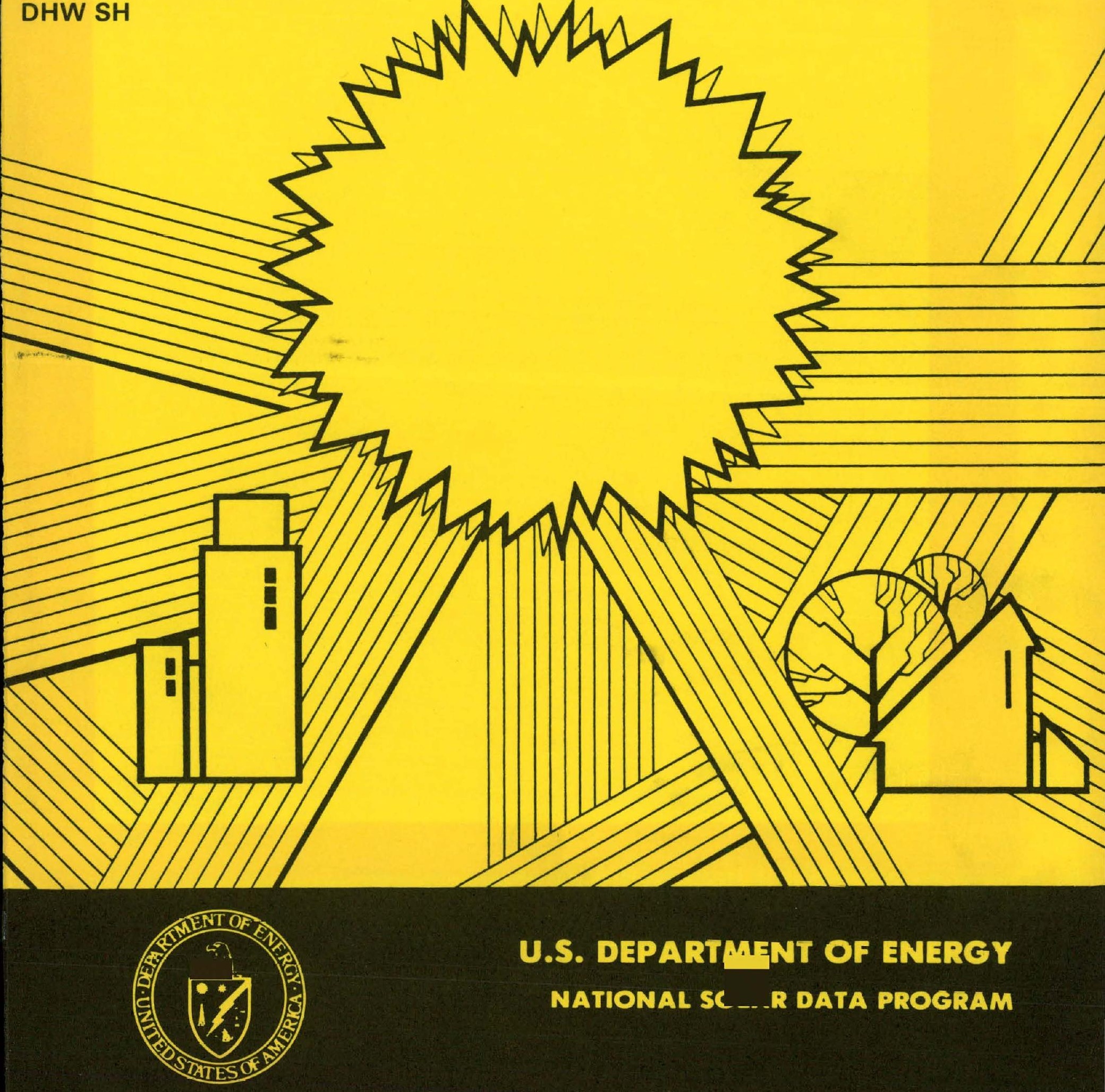

U.S. DEP ARTMENT OF ENERGY

NATIONAL SC _. .R DATA PROGRAM 


\section{DISCLAIMER}

This report was prepared as an account of work sponsored by an agency of the United States Government. Neither the United States Government nor any agency Thereof, nor any of their employees, makes any warranty, express or implied, or assumes any legal liability or responsibility for the accuracy, completeness, or usefulness of any information, apparatus, product, or process disclosed, or represents that its use would not infringe privately owned rights. Reference herein to any specific commercial product, process, or service by trade name, trademark, manufacturer, or otherwise does not necessarily constitute or imply its endorsement, recommendation, or favoring by the United States Government or any agency thereof. The views and opinions of authors expressed herein do not necessarily state or reflect those of the United States Government or any agency thereof. 


\section{DISCLAIMER}

Portions of this document may be illegible in electronic image products. Images are produced from the best available original document. 


\title{
DISCLAIMER
}

\begin{abstract}
"This report was prepared as an account of work sponsored by an agency of the United States Government. Neither the United States Government nor any agency thereof, nor any of their employees, makes any warranty, express or implied, or assumes any legal liability or responsibility fơ the accuracy, completeness, or usefulness of any information, apparatus, product, or plucess disclosed, or represents that its use would not infringe privately owned rights. Reference herein to any specific commercial product, process, or service by trade name, trademark, manufacturer, or otherwise, does not necessarily constitute or imply its endorsement, recommendation, or favoring by the United States Government or any agency thereof. The views and opinions of authors expressed herein do not necessarily state or reflect those of the United States Government or any agency thereof."
\end{abstract}

This report has been reproduced directly from the best available copy.

Available from the National Technical Information Service, U. S. Department of Commerce, Springfield, Virginia 22161.

Price: Printed Copy A06

Microfiche A01

Codes are used for pricing all publications. The code is determined by the number of pages in the publication. Information pertaining to the pricing codes can be found in the current issues of the following publications, which are generally available in most libraries: Energy Research Abstracts, (ERA); Governiment Reports Announcements and Index (GRA and I); Scientific and Technical Abstract Reports (STAR); and publication, NTIS-PR-360 available from (NTIS) at the above address. 
SUMMERWOOD ASSOCIATES, HOUSE M

OLD SAYBROOK, CONNECTICUT

SOLAR ENERGY SYSTEM PERFORMANCE EVALUATION

JUNE 1980 THROUGH MAY 1981

Prepared by Michael Raymond

Approved: $\frac{\text { D.M. Rossi for }}{\text { T. T. Bradshaw }}$

Vitro Laboratories Division

Automation Industries, Inc. 14000 Geurgia Avenue

Silver Spring, Maryland 20910

The National Solar Data Network

Department of Energy Contract Number DE-AC01-79CS30027

Contract Management by:

Argonue National Laboratory

9700 South Cass Avenue

Argonne, Illinois 60439

G. A. McGinnis, Project Manager 
THIS PAGE

\section{WAS INTENTIONALLY \\ LEFT BLANK}


FOREWORD

This report is one of a series which describes the performance of solar energy systems in the National Solar Data Network (NSDN) for the entire heating or cooling season. Domestic hot water is also included, if there is a solar contribution. Some NSDN installations are used solely for heating domestic hot water and annual performance reports are issued for such sites. In addition, Monthly Performance Reports, prior to 1981, are available for the solar systems in the network.

The National Solar Data Network consists of instrumented solar energy systems in buildings selected from among the 5,000 installations built (since early 1977) as part of the National Solar Heating and Cooling Demonstration Program. The overall purpose of this program is to assist in the development of solar technologies for buildings by providing data and information on the effectiveness of specific systems, the effectiveness of particular solar technologies, and the areas of potential improvement. Vitro Laboratories Division responsibility in the NSDN, under contract with the Department of Energy, is to collect data daily from the sites, analyze the data, and disseminate information to interested users.

Buildings in the National Solar Data Network are comprised of residential, commercial and institutional structures which are geographically dispersed throughout the continental United States. The variety of solar systems installed employ "active" mechanical equipment systems or "passive" design features, or both, to supply solar energy to typical building thermal loads such as space heating, space cooling, and domestic hot water. Solar systems on some sites are used to supply commercial process heat.

The buildings in the NSDN program are instrumented to monitor thermal energy flows to the space conditioning, hot water, or process loads, from both the solar system and the auxiliary or backup system. Data collection from each site, and transmission to a central computer for processing and analysis is highly automated. 


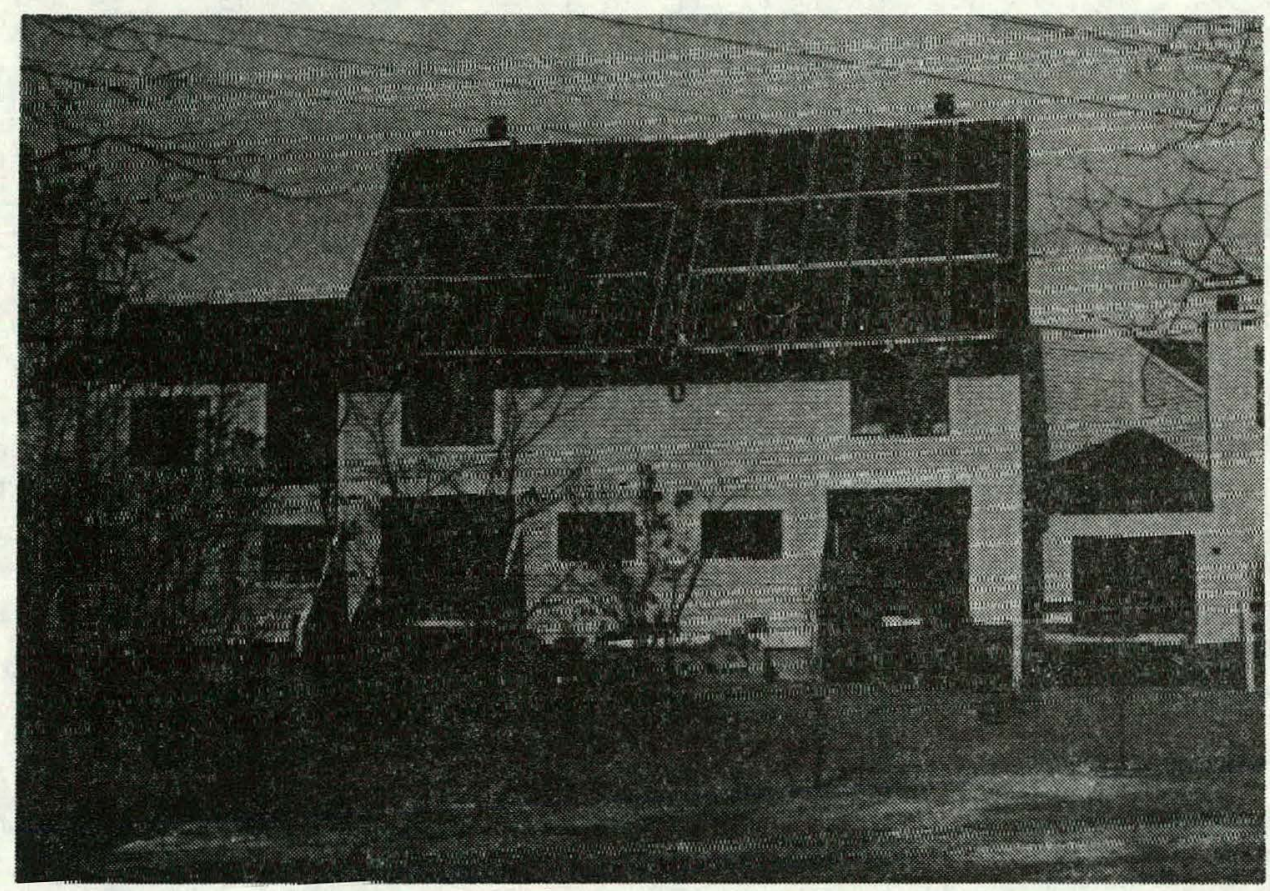

SUMMERWOOD ASSOCIATES, HOUSE M 
SUMMERWOOD ASSOCIATES, HOUSE M

Summerwood Associates, House $M$ is a single-family rowhouse residence, in 0ld Saybrook, Connecticut. The active solar energy system is designed to supply the following:

$$
\begin{aligned}
& \text { Annual Design Factors } \\
& \text { (Million BTU) }
\end{aligned}
$$

It is equipped with:

Collector

Storage

Auxiliary
378 square feet, Sunworks Solector IM LC

600-gallon site-built concrete tank in crawl space

Friedrich Climate Master V-22 12AW; 21,500 BTU/hr heat pump and electrical resistance heater
\% Solar

78

100

1. Information supplied by Wormser Scientific Corporation, the solar system designer. 
Foreword

iii

Site Summary

$\mathrm{v}$

Table of Contents

vi

List of Illustrations

vii

List of Tables

viii

1. SOLAR SYSTEM PERFORMANCE

1.1 Summary and Conclusious

1.2 System Operation

1.3 Solar Energy Utilization

$1-10$

1.4 Solar System Availability

$1-11$

2. SUBSYSTEM PERFORMANCE

2.1 Collector

2-1

2.2 Storage

$2-4$

2.3 Domestic Hot Water (DHW)

$2-6$

2.4 Space Heating

2-8

3. OPERATING ENERGY

4. ENERGY SAVINGS

5. WEATHER CONDITIONS

6. REFERENCES

Appendices

A. System Description A-1

B. Performance Evaluation Techniques $\quad$ B-1

C. Performance Factors and Solar Terms , , , . . C

n. Performance Equations

E. Calculation of Predicted Values

D-1

E-1

F. Meteorological Conditions

F-1

G. Site History, Prohlews, Changes in Solar System

G-1

H. Conversion Factors

H-1

I. Sensor Technology

I-1

J. Typical Monthly Data

$\mathrm{J}-1$ 


\section{LIST OF ILLUSTRATIONS}

Figure

Number

1

2

$3 a$

$3 b$

$3 c$

4

5

$6 a$

$6 b$

7

8

$A=1$

B-1
Title

$\underline{\text { Page }}$

Energy Flow Diagram for Summerwood Associates, House M, June 1980 through May 1981

$1-3$

System Thermal Performance, Summerwood Associates, House M, June 1980 through May 1981

$1-4$

Typical Insolation Data, Summerwood Associates, House M, March 20, 1981

$1-7$

$1-7$

Typical Collector Array Temperatures, Inlet/Outlet, Summerwood Associates, House M, March 20, 1981

Associates, House M, March 20, 1981

Summerwood

Typical System Operating Sequence, Summerwood

Associates, House M, March 20, 1981

$1-9$

Solar Energy Use, Summerwood Associates, House M, June 1980 through May 1981

$1-10$

Average Collector Efficiency, Summerwood Associates, House M, February 1981

$2-2$

Average Collector Efficiency, Summerwood Associates, House M, May 1981

DHW Subsystem Performance, Summerwood Associates, House M, June 1980 through May 1981

Space Heating Subsystem, Summerwood Associates, House M, June 1980 through May 1981

Summerwood Associates, House M Solar Energy System Schematic

$A-4$

The National Solar Data Network 
Solar System Thermal Performance, Summerwood

Associates, House M, June 1980 through May 1981

Solar Coefficient of Performance, Summerwood

Associates, House M, June 1980 through May 1981

Solar Energy Losses, Summerwood Associates,

House M, June 1980 through May 1981

Collector Subsystem Performance, Summerwood Associates, House M, June 1980 through May 1981

3Lurage Pértormance, Summerwood Associates, House M, June 1980 through May 1981

Domestic Hot Water Subsystem, Summerwood Associates, House M, June 1980 through May 1981

Space Heating Subsystem I, Summerwood Associates, House M, June 1980 through May 1981

Space Heating Subsystem II, Summerwood Associates, House M, June 1980 through May 1981

Solar Operating Finergy, Summerwoud Assoriates, House M, June 1980 through May 1981 
SECTION 1

SOLAR SYSTEM PERFORMANCE

SUMMERWOOD ASSOCIATES, HOUSE M

JUNE 1980 THROUGH MAY 1981

$\begin{array}{ll}\text { Solar Fraction } & \\ \text { Solar Savings Ratio } & 58 \% \\ \text { Conventional Fuel Savings }^{3} & 0.49 \\ \text { System Performance Factor }^{4} & 62 \% \\ \text { Solar System } \text { COP }^{5} & 6.67\end{array}$

Annual Energy Requirements June 1980 through May 1981

(Million BTU)

\begin{tabular}{lccc} 
& Total Load & Solar Contribution & \% Solar \\
\cline { 2 - 3 } Heating & 38.51 & 21.75 & 56 \\
Hot Water & 5.18 & 3.46 & 67
\end{tabular}

Envi ronmental Data

$\begin{array}{cc}\begin{array}{c}\text { Measured } \\ \text { Average }\end{array} & \begin{array}{c}\text { Long-Term } \\ \text { Average }\end{array} \\ \begin{array}{c}51^{\circ} \mathrm{F} \\ 5,842\end{array} & 52^{\circ} \mathrm{F} \\ 1,272 \mathrm{BTU} / \mathrm{ft}^{2} & 1,248 \mathrm{BTU} / \mathrm{ft}^{2}\end{array}$

1. Solar Fraction $=\frac{\text { Solar Energy Supplied to Load }}{\text { Total Load }} \times 100$

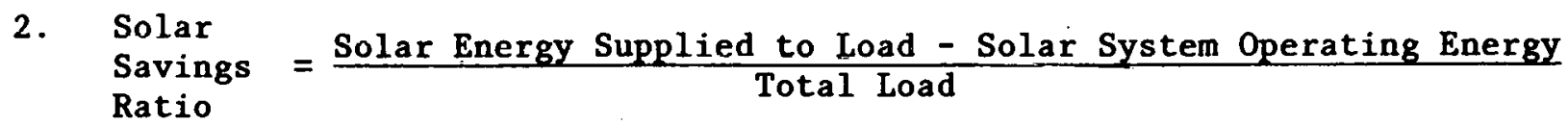

$\begin{aligned} & \text { Conventional } \\ & \text { Fuel Savings }\end{aligned}=$ Savings in BTU's $\times 292.8 \times 10^{-6} \mathrm{kwh} / \mathrm{BTU}$

4. Ratio of system load to the total equivalent fossil energy expended or required to support the system load

5. Solar

$\begin{aligned} & \text { Solar } \\ & \text { COPstem }\end{aligned}=\frac{\text { Solar Energy Used }}{\text { Solar Unique Operating Energy }}$ 


\subsection{SUMMARY AND CONCLUSIONS}

The solar energy system at Summerwood Associates, House M supplied $56 \%$ of the space heating energy requirement and $67 \%$ of the domestic hot water energy requirement in the 12-month period June 1980 through May 1981. The solar energy system saved $3,563 \mathrm{kwh}$ of electricity during the year.

The flow of energy through the solar system is presented in Figure 1. The overall performance of the solar energy system is presented in Table 1 and shown graphically in Figure 2. Performance was close to the $f$-Chart Version 4.0 prediction of a $62 \%$ solar fraction, but below the designers expectation of $78 \%$ solar fraction for space heating, and $100 \%$ for domestic hot water.

The collector array was efficient, collecting 45.22 million BTU out of 173,33 million BTU incident upon it. In the heating months (November through March), the array collected $41 \%$ of the incident solar energy. Nearly a11 the collected energy, $96 \%$, was delivered to storage as this is a drainback system with no heat exchanger berween collector and storage.

The storage subsystem was the only component with performance significantly poorer than expected. This poor performance is reflected in the high storage losses shown in the flow diagram, as 16.94 million BTU were lost out of 43.43 million BTU pumped into the tank. The effective $R$ value of the tank insulation was about $R-4$, based upon long-term energy flows into and out of the tank, and upon short-term tank temperature decay when no energy was pumped into or out of the tank. The insulation of the tank is thick (two inches styrofoam under tank, four inches on the sides and top) but some heat is apparently bypassing it.

Storage losses were low in November through January, because of low storage temperatures, but, in February and March, the storage losses were significant enough to hinder performance of the solar system. In the summer, losses were high, but there was much more solar energy available than needed for DHW loads. The penalty for the storage losses was the high operating energy required to run the collectors to maintain storage temperatures.

Summerwood Associates, House $M$ uses a dual-source heat pump system to deliver solar energy to the heating load. The heat pump evaporator is supplied with energy from either the storage tank or from ambient air. When the storage temperature was below $45^{\circ} \mathrm{F}$, ambient air was used for the energy source. The solar energy system is also designed to supply energy directly to the builuing when storage temperatures exceed $85^{\circ} \mathrm{F}$. At times, however, the control system did not work properly, and supplied water at $100^{\circ} \mathrm{F}$ or more to the heat pump evaporator, rather than to the direct space heating coil.

Heat pump systems often use the "nonpurchased" fraction to characterize their performance. This fraction includes the energy extracted from the air as well as the solar energy in the numerator. In Summerwood Associates, House $M$, the nonpurchased fraction was $67 \%$, compared to the f-Chart prediction of $68 \%$. For a parallel heat pump system, f-Chart predicts a $72 \%$ nonpurchased fraction.

Although the performance of the solar system is in good agreement with f-Chart predictions, the performance was less than the designer anticipated. There are several reasons for this lower performance. The design DHW solar fraction 


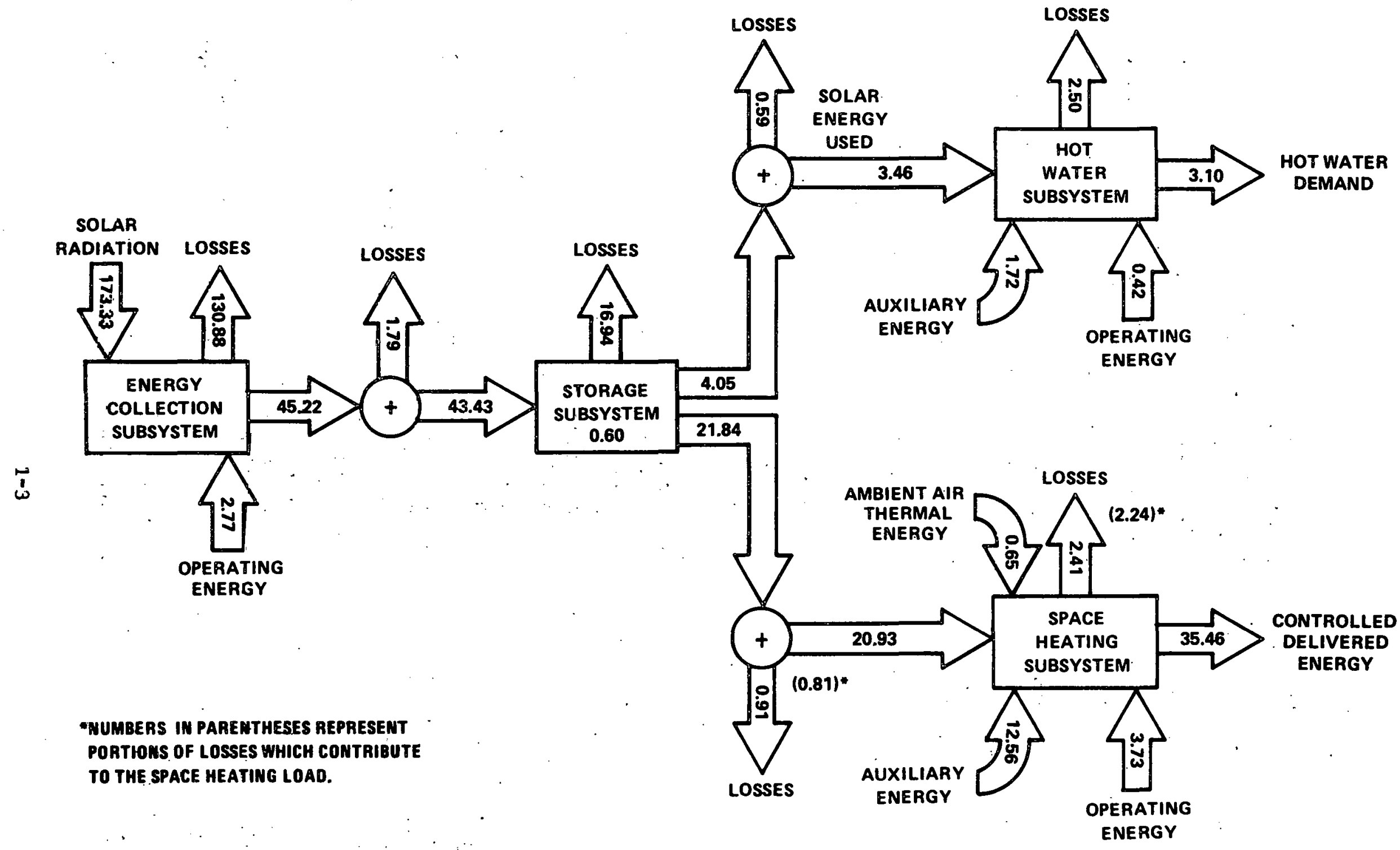

Figure 1. Energy Flow Diagram for Summerwood Associates, House M June 1980 through May 1981

(All figures in million BTU) 
Table 1. SOLAR SYSTEM THERMAL PERFORMANCE

\section{SUMMERWOOD ASSOCIATES, HOUSE M} JUNE 1980 THROUGH MAY 1981

(All values in million BTU, unless otherwise indicated)

\begin{tabular}{|c|c|c|c|c|c|c|c|c|c|}
\hline \multirow[b]{2}{*}{ MONTK } & \multirow{2}{*}{$\begin{array}{c}\text { SOLAR } \\
\text { ENERGY } \\
\text { COLLECTED }\end{array}$} & \multirow[b]{2}{*}{$\begin{array}{c}\text { SYSTEM } \\
\text { LOAD }\end{array}$} & \multicolumn{2}{|c|}{ SOLAR ENERGY USED } & \multirow{2}{*}{$\begin{array}{c}\begin{array}{c}\text { AUXILIARY } \\
\text { ENERGY }\end{array} \\
\text { ELECTRICAL }\end{array}$} & \multirow[b]{2}{*}{$\begin{array}{l}\text { OPERATING } \\
\text { ENERGY }\end{array}$} & \multirow{2}{*}{$\begin{array}{c}\begin{array}{c}\text { ENERGY } \\
\text { SAVINGS }\end{array} \\
\text { ELECTRICAL }\end{array}$} & \multicolumn{2}{|c|}{ SOLAR FRACTION $(\boldsymbol{q}) *$} \\
\hline & & & PREDICTED & MEASURED & & & & PREDICTED & MEASIRELD \\
\hline JUN & 2.61 . & 0.73 & 0.33 & 0.12 & 0.01 & 0.32 & 0.39 & 82 & 99 \\
\hline JUL & 3.15 & 0.66 & 0.63 & 0.65 & 0.01 & 0.37 & 0.28 & 96 & 98 \\
\hline AUG & 1.48 & 0.22 & 0.25 & 0.10 & 0.12 & 0.16 & -0.04 & 49 & 46 \\
\hline SEP & 0.56 & 0.40 & 0.56 & 0.08 & 0.32 & 0.03 & 0.06 & 100 & 21 \\
\hline OCT & 3.65 & 1.15 & 0.97 & 0.98 & 0.02 & 0.32 & 0.40 & 79 & R5 \\
\hline มกy & 3.13 & 6.61 & 4.00 & 4.45 & $0 .: 10$ & 0.78 & 2.09 & 59 & 67 \\
\hline DEC & 6:0's & 10.20 & 5.11 & 4.72 & 5.10 & 1.41 & 3.21 & 40 & $4 \pi$ \\
\hline JAN & 5.26 & 11.89 & $5 \eta$ & 4.00 & 5.94 & 1.27 & 3.32 & 43 & 39 \\
\hline FEB & 4.54 & 4.87 & 3.91 & 3.44 & 1.19 & 0.75 & 0.72 & 80 & 71 \\
\hline MAR & 6.09 & 5.69 & 5.46 & 4.14 & 1.27 & 0.88 & 1.31 & 94 & 73 \\
\hline APR & 3.59 & 0.70 & 0.55 & 0.69 & 0.00 & 0.28 & 0.26 & 64 & 99 \\
\hline MAY & 4. 31 & 0.57 & 0.63 & 0.57 & 0.00 & 0.34 & 0.17 & 80 & 98 \\
\hline TOTAL & 45.22 & 63.69 & 27.83 & 25.20 & 14.28 & 6.91 & 12.17 & - & - \\
\hline AVERAGE & 3.77 & 3.64 & 2.32 & 2.10 & 1.19 & 0.58 & 1.01 & 62 & 58 \\
\hline
\end{tabular}

*Predicted performance was detemined from an $f$-Chart 4.0 computer simulation using measured weather and measured subsystem loads as input.

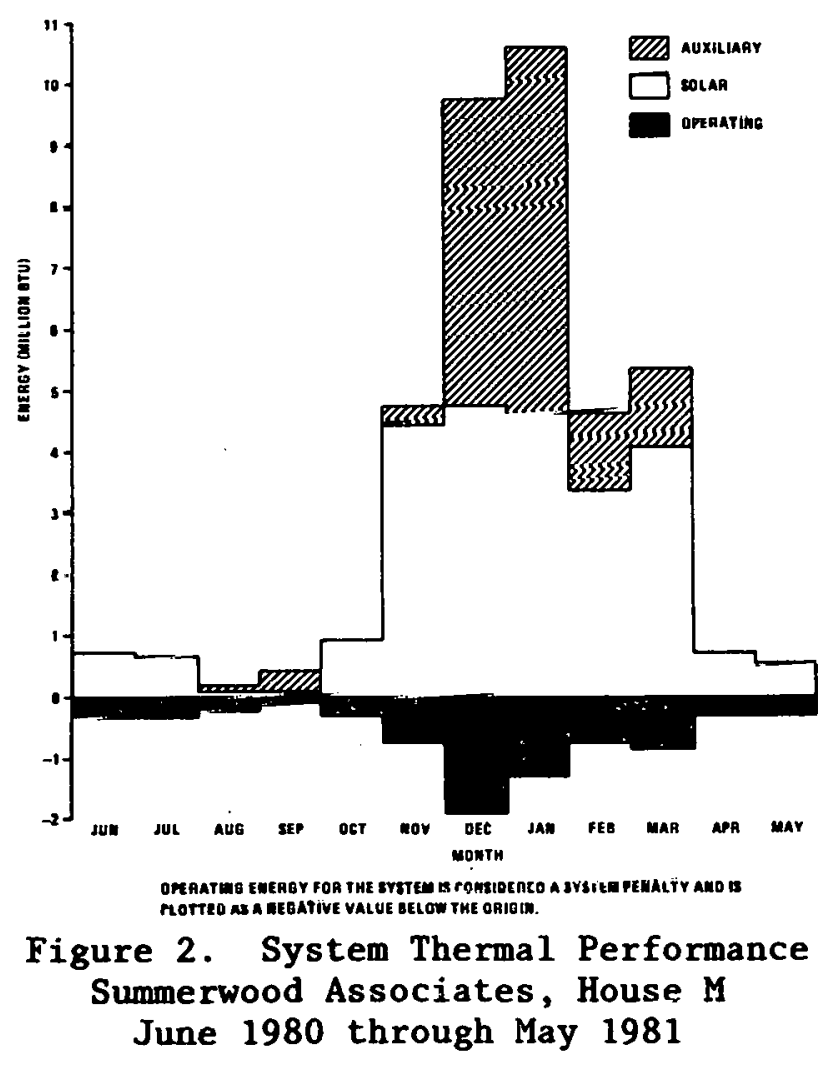


of $100 \%$ is unattainable because of the space heating subsystem. The heat pump system for space heating uses stored heat as $10 \mathrm{w}$ as $45^{\circ} \mathrm{F}$, so the storage tank temperature is often in the $50^{\prime} \mathrm{s}$ and $60^{\prime} \mathrm{s}$ in the winter, and almost never reaches the $\mathrm{DHW}$ temperature of $130^{\circ} \mathrm{F}$. The collector array would have to be considerably oversized to have a $100 \%$ DHW solar fraction in the winter. (The DHW solar fraction was about $100 \%$ in the summer.) The space heating subsystem achieved a $56 \%$ solar fraction versus the $78 \%$ expected by the designers. The weather conditions were contributory causes, as the fall and winter (through January) were very much colder than normal.

The measured heating load of 38.51 million BTU was smaller than the predicted load of 43.40 million BTU. This difference was largely due to the low average house temperature, $61^{\circ} \mathrm{F}$ in January and February (which was partly because the heating system was undersized). Another factor in the lower load is that the house is not occupied every day of the year. The house was vacant 11 days in the winter (December-February), and 115 days scattered fairly evenly throughout the rest of the year.

Operating energy offset most of the savings in the summer, but was quite reasonable in the winter. Solar specific operating energy averaged about 0.40 million BTU per month in the winter, compared to about 5.00 million BTU of solar energy used per month. In the summer, about 0.30 million BTU of operating energy were used each month to deliver about 0.65 million BTU of solar energy. This high summer operating energy effect can also be seen in Table 2, Solar Coefficient of Performance (COP).

\section{Table 2. SOLAR COEFFICIENT OF PERFORMANCE}

SUMMERWOOD ASSOCIATES, HOUSE M JUNE 1980 THROUGH MAY 1981

\begin{tabular}{|c|c|c|c|c|}
\hline MONTH & $\begin{array}{c}\text { SOLAR } \\
\text { ENERGY SYSTEM }\end{array}$ & $\begin{array}{l}\text { COLLECTOR } \\
\text { SUBSYSTEM }\end{array}$ & $\begin{array}{l}\text { DOMESTIC HOT } \\
\text { WATER SOLAR }\end{array}$ & $\begin{array}{c}\text { SPACE HEATING } \\
\text { SOLAR }\end{array}$ \\
\hline JUN & 2.25 & 10.44 & 11.27 & * \\
\hline JUL & 1.76 & 10.50 & 9.03 & NA \\
\hline AUG & 0.71 & 13.45 & 3.03 & NA \\
\hline SEP & 2.67 & 28.00 & 13.67 & NA \\
\hline OCT & 3.24 & 15.87 & 9.31 & * \\
\hline NOV. & 13.09 & 19.00 & 15.61 & 38.90 \\
\hline DEC & 8.91 & 17.96 & 16.58 & 18.00 \\
\hline JAN & 12.59 & 18.79 & 2.75 & 99.80 \\
\hline FEB & 9.32 & 19.74 & 3.25 & 31.80 \\
\hline MAR & 10.35 & 19.65 & 11.38 & 52.43 \\
\hline APR & 2.65 & 16.32 & 8.39 & 39.00 \\
\hline MAY & 1.73 & 15.39 & 13.89 & $\star$ \\
\hline $\begin{array}{l}\text { WEIGHTED } \\
\text { AVERAGE }\end{array}$ & 6.67 & 16.32 & 8.24 & 35.47 \\
\hline
\end{tabular}


The COP simply provides a numerical value for the relationship of solar energy used or collected and the energy required to collect or deliver it. The greater the COP value, the more efficient the subsystem. The solar energy system at Summerwood Associates, House $M$ functioned at a reporting period weighted average COP value of 6.67 for the period June 1980 through May 1981 .

The COP was high during the heating season, November through March, but was low the rest of the year when most of the solar energy was lost from the storage and DHW tanks, rather than being used to satisfy loads.

\subsection{SYSTEM OPERATION}

\subsubsection{TYPICAL SYSTEM OPERATION}

Curves showing typical system operation on a rlear day (March 20, 1981) are presented in tigures $3 a, 3 b$ and $3 c$. Figure $3 a$ showo the outduur Lemperacure and che insolation on the collector array. The plot indicates the time during which the collectors were operating. On this day the collector pump turned on briefly at 8:27 a.m., and then commenced normal operation at 8:39 a.m. The array operated continuously until 3:40 p.m., cycled back on briefly at $3: 50$ p.m., and then shut down.

Figure $3 b$ shows the collector inlet and outlet temperatures. The inlet temperature sensor is on the roof, and its reading approaches outdoor ambient when the collector pump is not running. The minimum range of these sensors is $32^{\circ} \mathrm{F}$. The collector outlet temperature sensor is in the attic, reading about $43^{\circ} \mathrm{F}$ until sunrise.

When the collector pump turned on at 8:27 a.m., the inlet, temperature rose rapidly to $68^{\circ} \mathrm{F}$, the temperature of the water in the bottom of the storage tank. As the absorber plates, preheated by two hours of morning sunshine (insolation was $130 \mathrm{BTU} / \mathrm{ft}^{2}$ at $8: 27 \mathrm{a} . \mathrm{m}$. ), heated the incoming water, they were cooled down. This apparently caused the pump to shut off. The inlet sensur recorded a temperature of $85^{\circ} \mathrm{F}$ as the water drained back to the storage tank. The collector pump turned on again at $8: 37 \mathrm{a} . \mathrm{m}$. and remained on until afternoon. The collectors are supposed to turn on when the collector-storage temperature differential is $15^{\circ} \mathrm{F}$, and turn off when the differential falls to $2^{\circ} \mathrm{F}$. Vitro temperature sensors do not give a direct indication of the operation of the control system as the absorber plate temperature, and the temperature of the storage tank at the 1nrations of the contrul sensors are not monitored. The operation of controls on this day was typical for this system, however, with one extra cycle at. pach end, but no other prublems. At solar noon (12:20 p.m.) the temperature rise through the collectora was 7.5.5. The flow meter read $17.3 \mathrm{gpm}$ (all day), giving a collection rate of $65,000 \mathrm{BTU} / \mathrm{hr}$. Insolation on the collectors was $326 \mathrm{BTU} / \mathrm{ft}^{2}-\mathrm{hr}$, on 373 square feet of collector, a total of 121,600 BTU, so collector efficiency was $53 \%$. The operating point was $0.20^{\circ} \mathrm{F}-\mathrm{ft}^{2}-\mathrm{hr} \mathrm{BTU}^{-1}$. The measured energy collected for the whole day (seven hours of operation) was 394,000 BTU. 


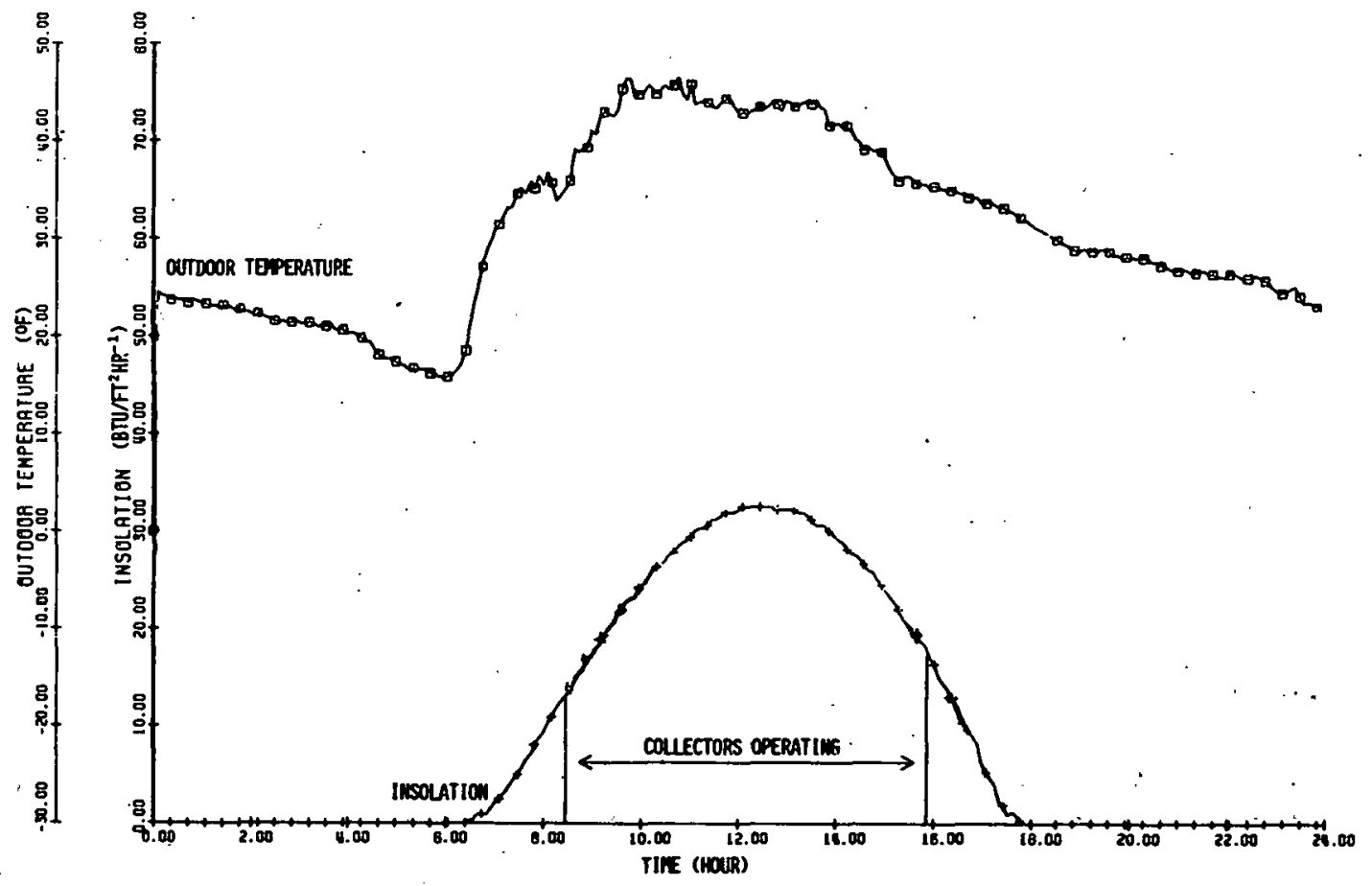

Figure 3a. Typical Insolation Data

Summerwood Associates, House M

March 20, 1981

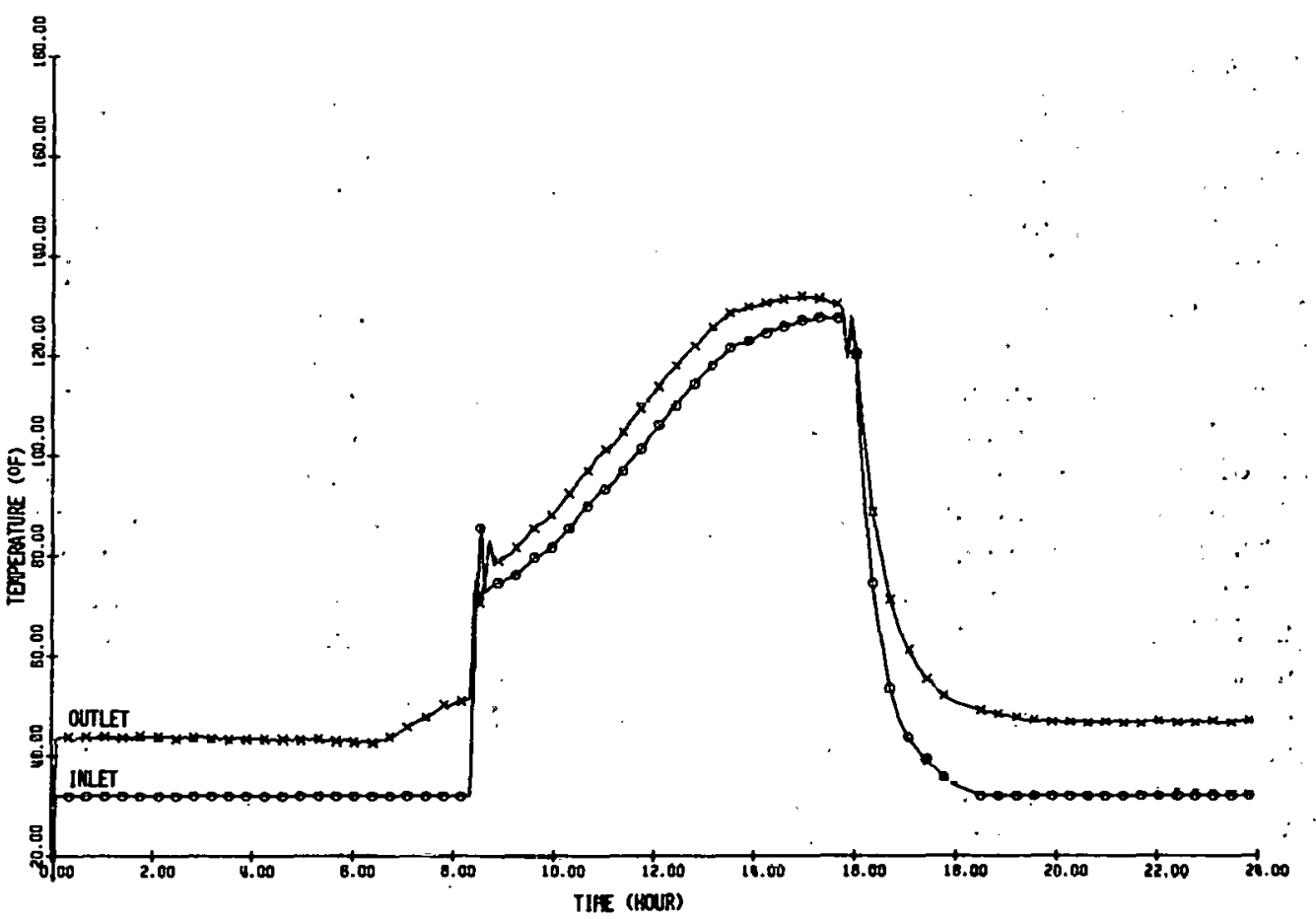

Figure 3b. Typical Collector Array Temperatures, Inlet/Outlet Summerwood Acsociates, House M

March 20, 1981 
The storage tank temperatures are shown in Figure 3c. During the hours of collector operation, the storage temperature rose from $75^{\circ} \mathrm{F}$ to $129^{\circ} \mathrm{F}$, a rise of $54^{\circ} \mathrm{F}$. For a $600-\mathrm{gallon}$ tank, this is an increase of $270,000 \mathrm{BTU}$. Energy was being drawn out of the tank for DHW and space heat during this period. The DHW preheat pump came on at $1: 40 \mathrm{p} . \mathrm{m}$. and remained on until 6:00 p.m. During the period of collector operation, 14,000 BTU were drawn from storage to the DHW subsystem. In the morning, water was drawn from storage several times for the heat pump evaporator. The total energy drawn from storage for space heating was 25,000 BTU during the period of collector operation. This would imply a storage loss of 85,000 BTU in the seven hours of collector operation. During this time, the average storage temperature was $102^{\circ} \mathrm{F}$ and the storage environment averaged $65^{\circ} \mathrm{F}$. These temperatures imply an $R$ value of about 0.5 , which is much too low. This calculation was repeated for a number of days throughout the year, with similar results. For this reason, and as a result of further calculatious explained in the collector subsystem section, it was determined that the actual collector flow was 14.7 , rather than 17.3 gallons per minute. This flow rate makes the actual energy collected eyual lo $335,000 \mathrm{BTU}$, wilh a storage loss of $26,000 \mathrm{BTU}$, and an $\mathrm{R}$ value of 1.6 , which is still very low. The long-term average measured $R$ value was 3.4 .

A11 the space heating demands were satisfied by either direct solar or the solar-assisted heat pump. From midnight to $6: 15$ a.m., storage temperature fell to $84^{\circ} \mathrm{F}$ (top) and $77^{\circ} \mathrm{F}$ (bottom) and the system switched to the heat pump. The heat pump cycled on five times, for about 20 minutes each time, until 11:00 a.m. No further heat was needed until 5:55 p.m., at which time the storage tank was warm enough for direct solar heat. Direct solar was used for all heating until the end of the day. The drops in storage temperature when heating draws are made are apparent in the plots.

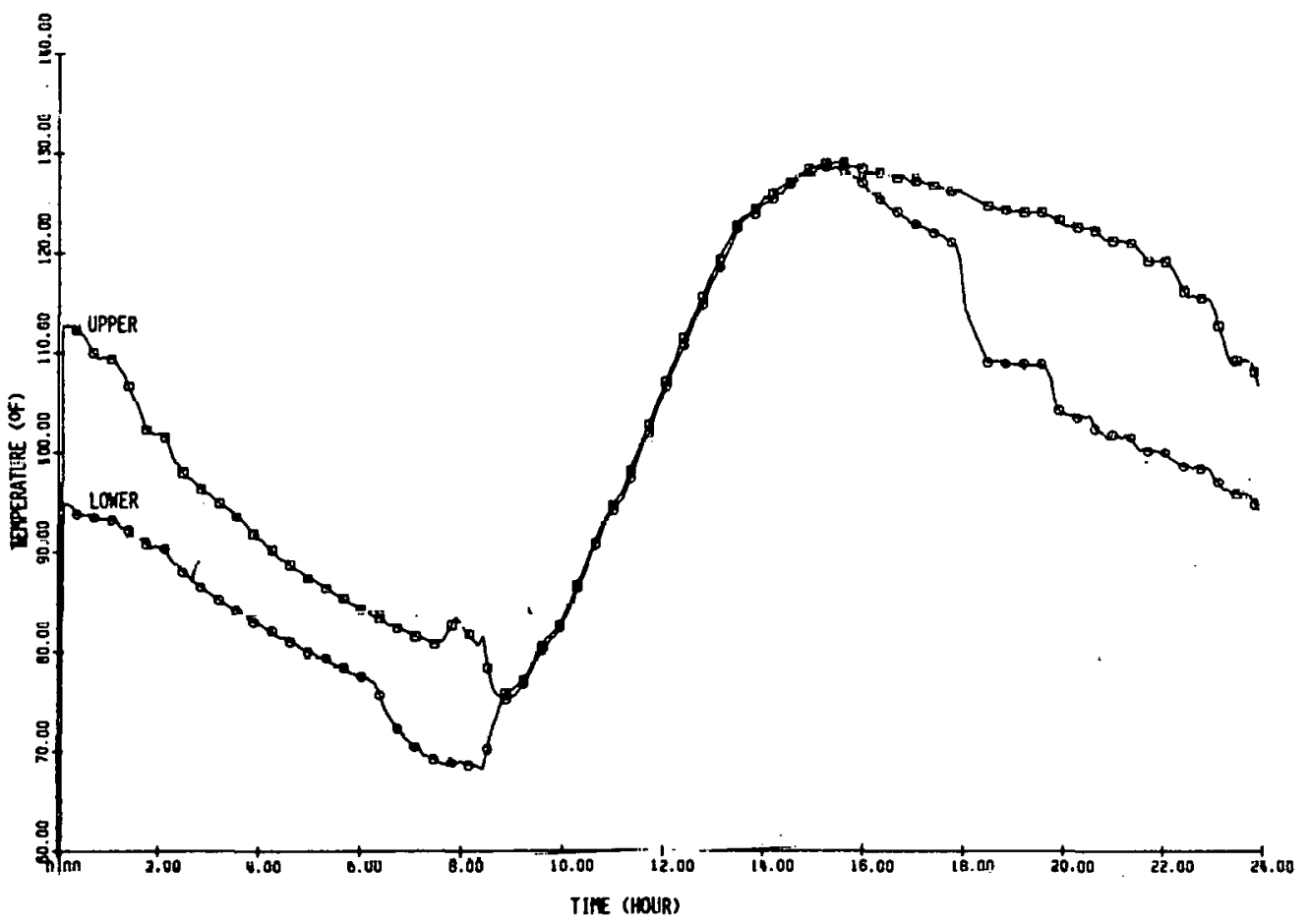

Figure 3c. 'Typical Storage Fluid Temperatures

Summerwood Associates, House M

March 20, 1981 


\subsubsection{SYSTEM OPERATING SEQUENCE}

Figure 4 presents a bar chart showing the system operating sequences for March 20,1981 .

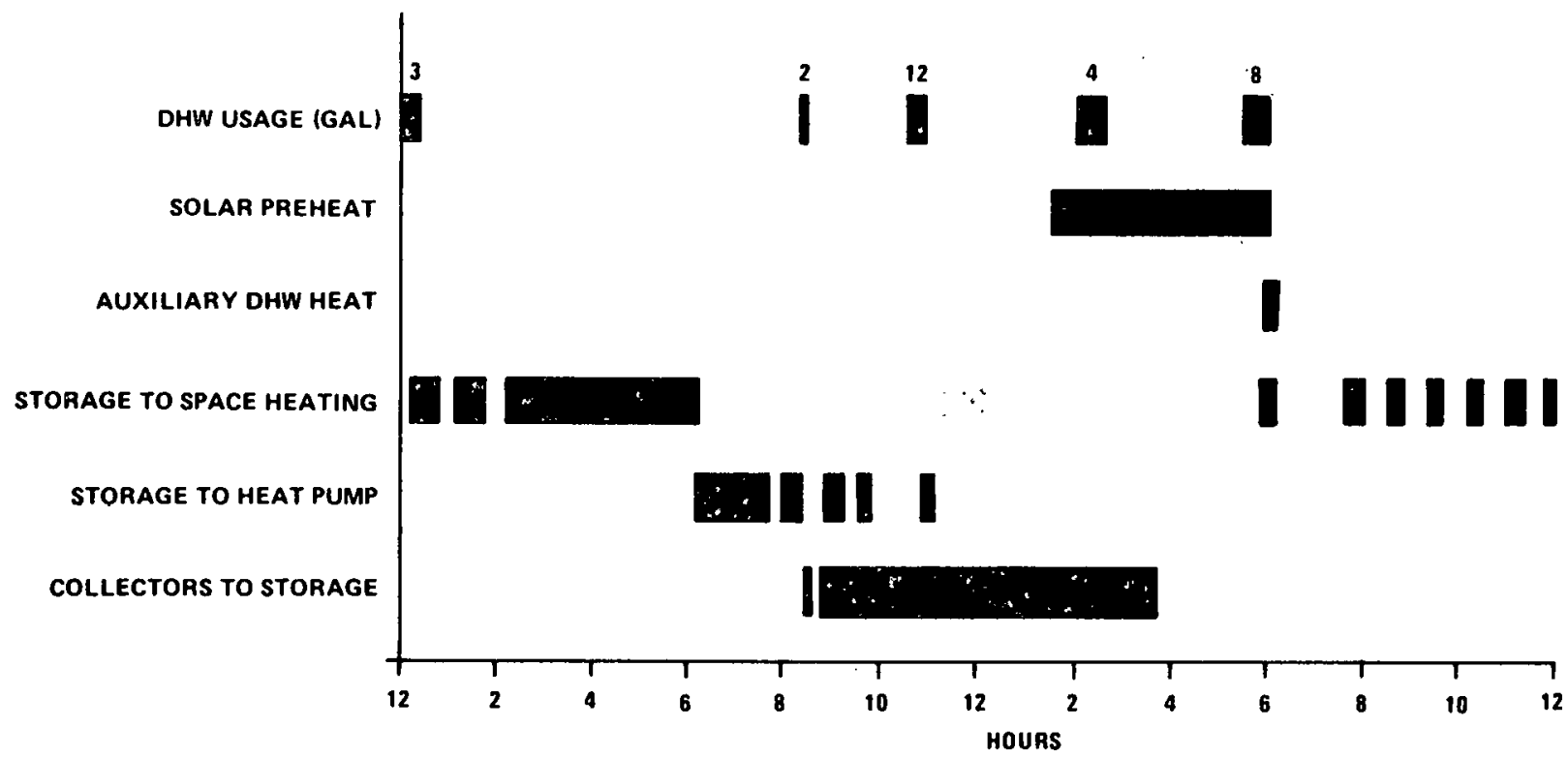

Figure 4. Typical System Operating Sequence Summerwood Associates, House M March 20, 1981

The domestic hot water preheat loop ran from 1:30 to 6:00 p.m. The loop is designed to operate when the DHW tank temperature falls $15^{\circ} \mathrm{F}$ below the solar storage tank temperature, and to continue running until the differential is $6^{\circ} \mathrm{F}$. The DHW tank temperature was $113^{\circ} \mathrm{F}$ when the pump turned on at $1: 30 \mathrm{p} . \mathrm{m}$. and rose to $124^{\circ} \mathrm{F}$ at $3: 30 \mathrm{p} . \mathrm{m}$. Further circulatiun from $3: 30$ to $\mathrm{h}: 00 \mathrm{p} . \mathrm{m}$. did not succeed in raising the tank temperature. The operating energy loss was small, as the pump draws only 88 watts. The auxiliary DHW heater turned on for 10 minutes at $6 \mathrm{p} . \mathrm{m}$., the only time it was needed on this day.

The space heating system worked well, using direct solar energy until 6:20 a.m. when the solar-assisted heat pump took over. The thermostat was apparently raised at this time, from about $63^{\circ} \mathrm{F}$ to $67^{\circ} \mathrm{F}$. The storage tank temperature had fallen to near $80^{\circ} \mathrm{F}$, the lowest temperature for usable direct solar heating. After the collectors boosted the storage temperature, direct solar heating was again used in the evening. 


\subsection{SOLAR ENERGY UTILIZATION}

Figure 5 shows the use of solar energy and the percentage of losses.

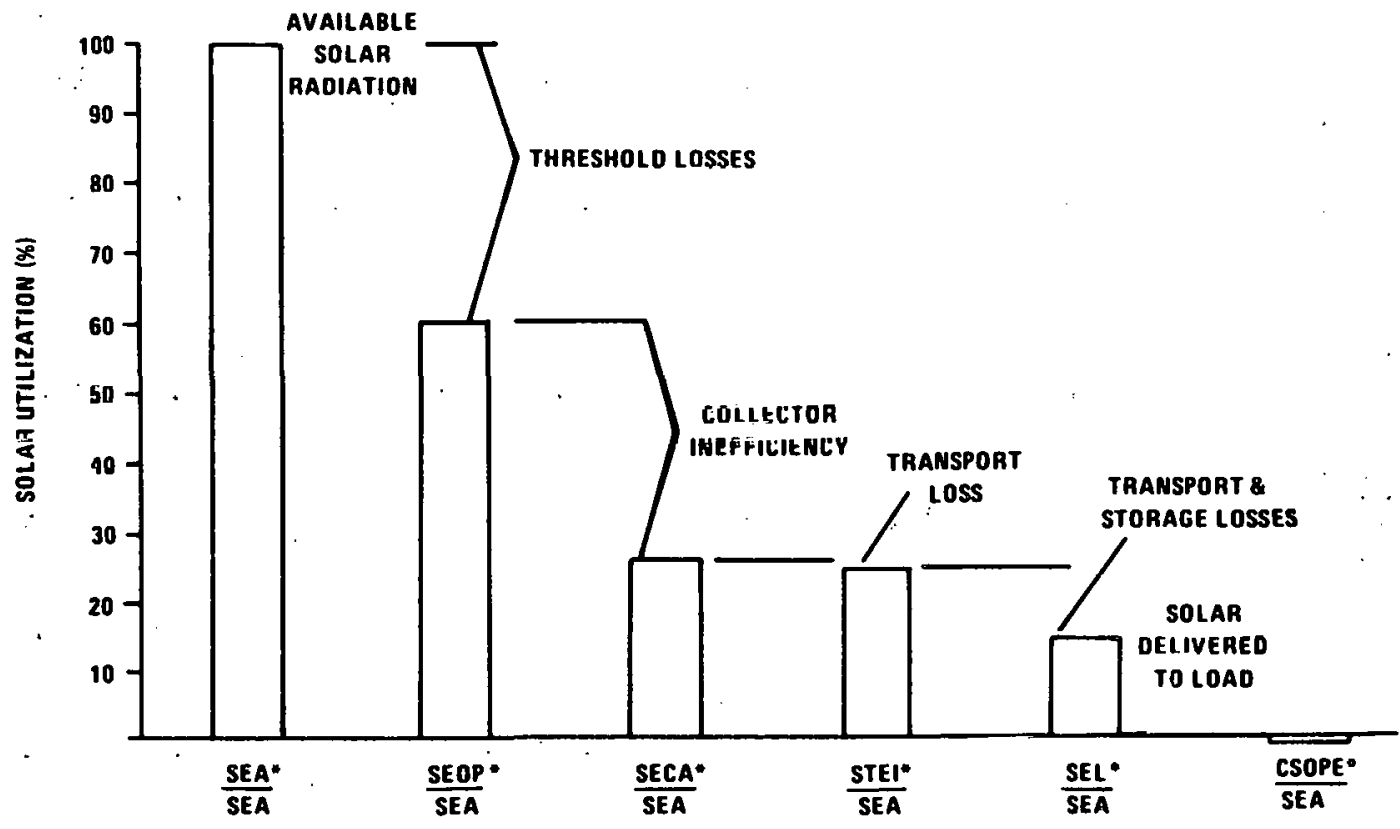

- RefER to APPENOIX C fOR definItIONS OF these aCRONYMS

Figure 5. Solar Energy Use Summerwood Associales, House M June 1980 through May 1981

The losses of solar energy at the different stages through the system, from incident radiation to the load, are also presented in Table 3. $\cdots$

Over the year, the collectors were operated only $60 \%$ of the time there was radiation. This percentage varied greatly with the season. In the summer, the load was small and the collectors shut off because lie tank temperature had reached ILs upper limit. In the winter, this percentage was about $80 \%$. While the collectors were operating, $43 \%$ of the insolation was collected. This percentage was a good value for annual performance. Collector-to-storage transport losses were small. Storage losses were larger than they should have been, as heat was apparently bypassing the insulation. The large measured storage-to-hot water transport losses are probably not real. They were probably part of the DHW tank losses, but a small temperature sensor bias made them appear to be line losses. A comparison of estimated and measured DHW tank losses (sec DHW subsection) reveals that nearly all the energy leaving storage for the DHW tank reached the DHW tank. 
Table 3. SOLAR ENERGY LOSSES

SUMMERWOOD ASSOCIATES, HOUSE - $M$ JUNE 1980 THROUGH MAY 1981

JUN JUL AUG SEP OCT NOV DEC JAN FEB MAR APR MAY

1. SOLAR ENERGY (SE) COLLECTED - SE DIRECTLY TO LOADS (million BTU)

$\begin{array}{llllllllllll}2.61 & 3.15 & 1.48 & 0.56 & 3.65 & 5.13 & 4.85 & 5.26 & 4.54 & 6.09 & 3.59 & 4.31\end{array}$

2. SE TO STORAGE (million BTU)

$\begin{array}{llllllllllll}2.49 & 3.15 & 1.34 & 0.43 & 3.05 & 4.88 & 4.85 & 5.13 & 4.54 & 6.09 & 3.48 & 4.00\end{array}$

3. LOSS - COLLECTOR TO STORAGE ( )

$\begin{array}{llllllllllll}5 & 0 & 9 & 23 & 16 & 5 & 0 & 2 & 0 & 0 & 3 & 7\end{array}$

4. CHANGE IN STORED ENERGY (million BTU)

$\begin{array}{llllllllllll}-0.02 & 0.13 & -0.11 & 0.07 & -0.07 & -0.01 & -0.15 & 0.14 & 0.03 & 0.41 & -0.13 & 0.31\end{array}$

5. HOT WATER SOLAR ENERGY (HWSE) FROM STORAGE (million BTU)

6. LOSS - STORAGE TO HWSE (\%)

$54 \quad 62$

$\begin{array}{llll}0.10 & 0.00 & 0.00 & 0.00\end{array}$

0.62

4.1

4.52

$4.55 \cdot 3.32$

3.90

8. LOSS - STORAGE

TO HSE (\%)

*Denotes unavailable data.

\subsection{SOLAR SYSTEM AVAILABILITY}

The solar system was switched off frequently in August and September because of a control system problem. The collectors were shut off August 12-23, 25, August 28 - September 3, September 7-17, and September -19-26. and 29:.. Solar energy was used for hot water preheating on only 11 days in August and four days in September. There were no system problems during the year. 


\section{SECTION 2}

\section{SUBSYSTEM PERFORMANCE}

\subsection{COLLECTOR}

Summerwood Associates, House $M^{\prime}$ 's collector array is composed of 18 Sunworks Solector flat-plate collectors which use water as the heat transfer fluid. The panels are mounted on the roof in three rows of six collectors each, tilted at an angle of 50 degrees. The array faces 12 degrees west of south. All 18 panels are plumbed in parallel. The flow through the array is relatively high, 15 gallons per minute, or about $0.04 \mathrm{gal} / \mathrm{sq} . \mathrm{ft}$.

Collector subsystem performance for Summerwood Associates, House $M$ is presented in Table 4.

Table 4. COLLECTOR SUBSYSTEM PERFORMANCE

SUMERWOOD ASSOCIATES, HOUSE M JUNE 1980 THROUGH MAY 1981

(All values in million BTU, unless otherwise indicated)

\begin{tabular}{|c|c|c|c|c|c|c|c|c|c|}
\hline MONTH & $\begin{array}{l}\text { INCIDENT } \\
\text { SOLAR } \\
\text { RADIATION }\end{array}$ & $\begin{array}{l}\text { COLLECTED } \\
\text { SOLAR } \\
\text { ENERGY }\end{array}$ & $\begin{array}{c}\text { COLLECTOR } \\
\text { SUBSYSTEM } \\
\text { EFTICIENCY } \\
(\%)\end{array}$ & $\begin{array}{l}\text { OPERATIONAL } \\
\text { INCIDENT } \\
\text { ENERGY }\end{array}$ & $\begin{array}{l}\text { COLLECTOR } \\
\text { ARRAY } \\
\text { OPERATIONAL } \\
\text { EFFICIENCY } \\
\text { (\%) }\end{array}$ & $\begin{array}{c}\text { ECSS } \\
\text { OPERATING } \\
\text { ENERGY }\end{array}$ & $\begin{array}{l}\text { SOLAR } \\
\text { ENERGY } \\
\text { DIRECTLY } \\
\text { TO LOADS }\end{array}$ & $\begin{array}{l}\text { SOLAR } \\
\text { ENERGY } \\
\text { TO } \\
\text { STORAGE }\end{array}$ & $\begin{array}{c}\text { DAYTIME } \\
\text { AMBIENT } \\
\text { TEMPERATURE } \\
\left({ }^{\circ} \mathbf{F}\right)\end{array}$ \\
\hline JUN & 14.95 & 2.61 & 17 & 9.80 & 27 & 0.25 & 0.0 & 2.49 & 75 \\
\hline JUL & 17.52 & 3.15 & 18 & 11.14 & 28 & 0.30 & 0.0 & 3.15 & 85 \\
\hline AUG & 15.92 & 1.48 & 9 & 4.11 & 36 & 0.11 & 0.0 & 1.34 & 84 \\
\hline SEP & 17.45 & 0.56 & 3 & 0.66 & 85 & 0.02 & 0.0 & 0.43 & 77 \\
\hline OCT & 13.03 & 3.65 & 28 & 9.14 & 40 & 0.23 & 0.0 & 3.05 & 60 \\
\hline Nov & 11.85 & 3.13 & 43 & 9.41 & $55^{4}$ & 0.27 & 0.0 & 4.88 & 48 \\
\hline DEC & 11.45 & 4.85 & 42 & 9.12 & 53 & 0.27 & 0.0 & 4.85 & 35 \\
\hline JAN & 12.23 & 5.26 & 42 & 9.85 & 33 & 0.28 & 0.0 & 5.13 & 29 \\
\hline FEB & 11.13 & 4.54 & 41 & 8.58 & 53 & 0.23 & 0.0 & 4.54 & 43 \\
\hline MAR & 15.70 & 6.09 & 39 & 11.96 & 51 & 0.31 & 0.0 & 6.09 & 46 \\
\hline APR & 15.01 & 3.59 & 24 & 9.19 & 39 & 0.22 & 0.0 & 3.48 & 57 \\
\hline MAY & 17.09 & 4.31 & 25 & 11.02 & 39 & 0.28 & 0.0 & 4.00 & 68 \\
\hline TOTAL & 173.33 & 4.5 .22 & - & 103.98 & - & 2.77 & 0.0 & 43.43 & - \\
\hline AVERAGE & 14.44 & 3.77 & 26 & 8.67 & 43 & 0.23 & 0.0 & 3.62 & 59 \\
\hline
\end{tabular}

Collector subsystem performance was excellent throughout the year. In the summer, efficiencies are low because of the very high inlet temperatures, and because the collectors do not need to run very long to keep the storage tank 
hot enough to satisfy the small DHW load. This only means that subsystem efficiency is not a good characterization of summer collector performance. In the winter, inlet temperatures are low and loads are large, resulting in high collector efficiencies. Throughout the year, the control system performed well, with a very small amount of extra cycling, and the panels themselves performed to design efficiency or better.

\subsubsection{SEASONAL COLLECTOR ARRAY EFFICIENCY}

Figures $6 \mathrm{a}$ and $6 \mathrm{~b}$ show monthly performance of the collector array for February and May 1981. The collector array efficiency curve is compared to the manufacturer's standard (ASHRAE 93-77/NBSIR 74-635) collector efficiency curve. The instantaneous collector efficiencies are plotted agaiust the collector operating pnint, dcfined as the temperature difference betwecn the collector inlet temperature and the ambient remperature, divided by insolation per unit collector area.

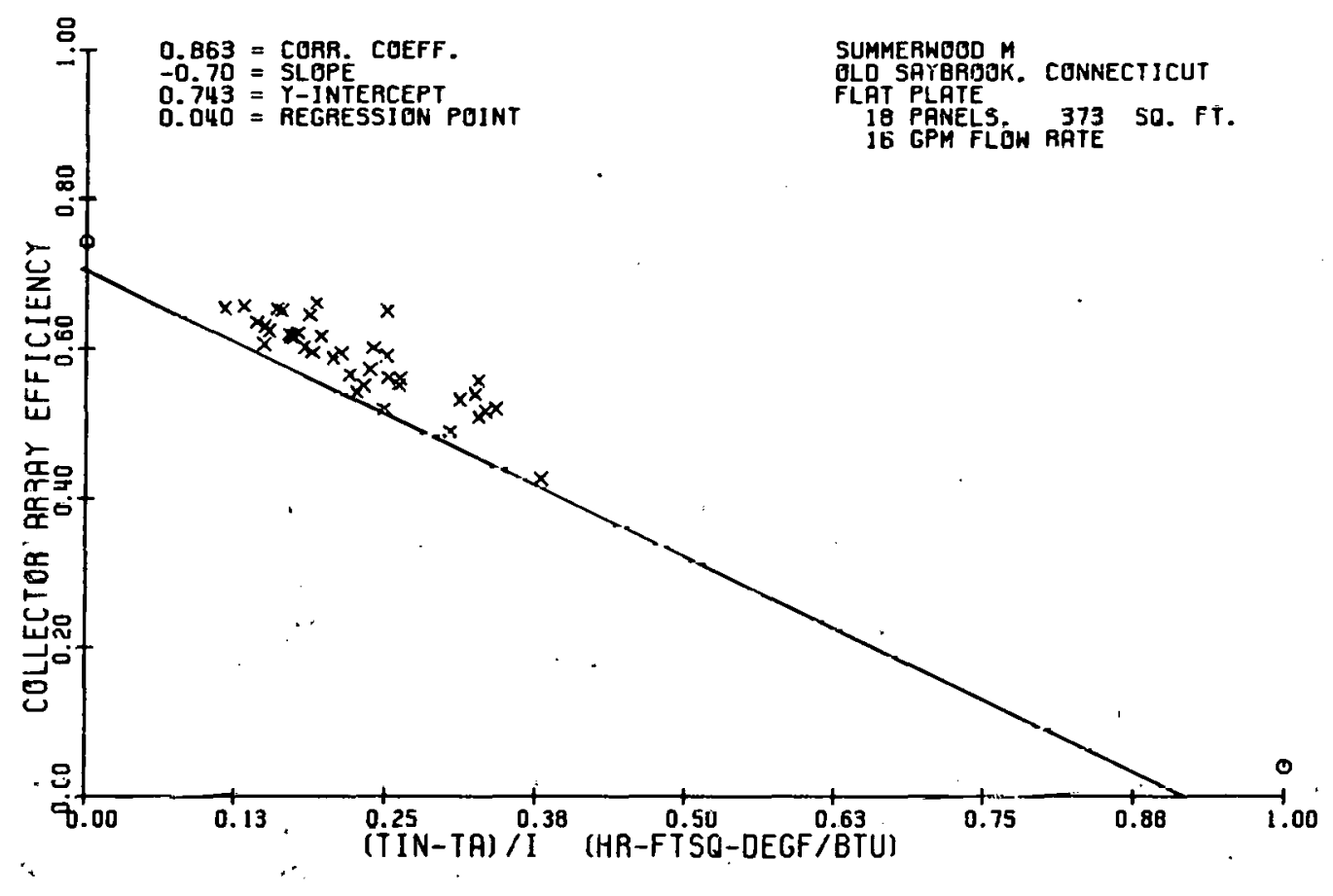

Figure 6a. Average, Collcctor Efficiency Summerwood Associates, House M February 1981

The collector efficiencies are consistently higher than the manufacturers single-panel ASHRAE test data. The only phenomenon that might account for this is the reduction in edge losses when the individual collectors are set out in an array, but this effort is too small to account for this efficiency increase. The efficiency of the array as a whole could be at most about five percent above the single-panel curve of edge loss reduction; our measured 


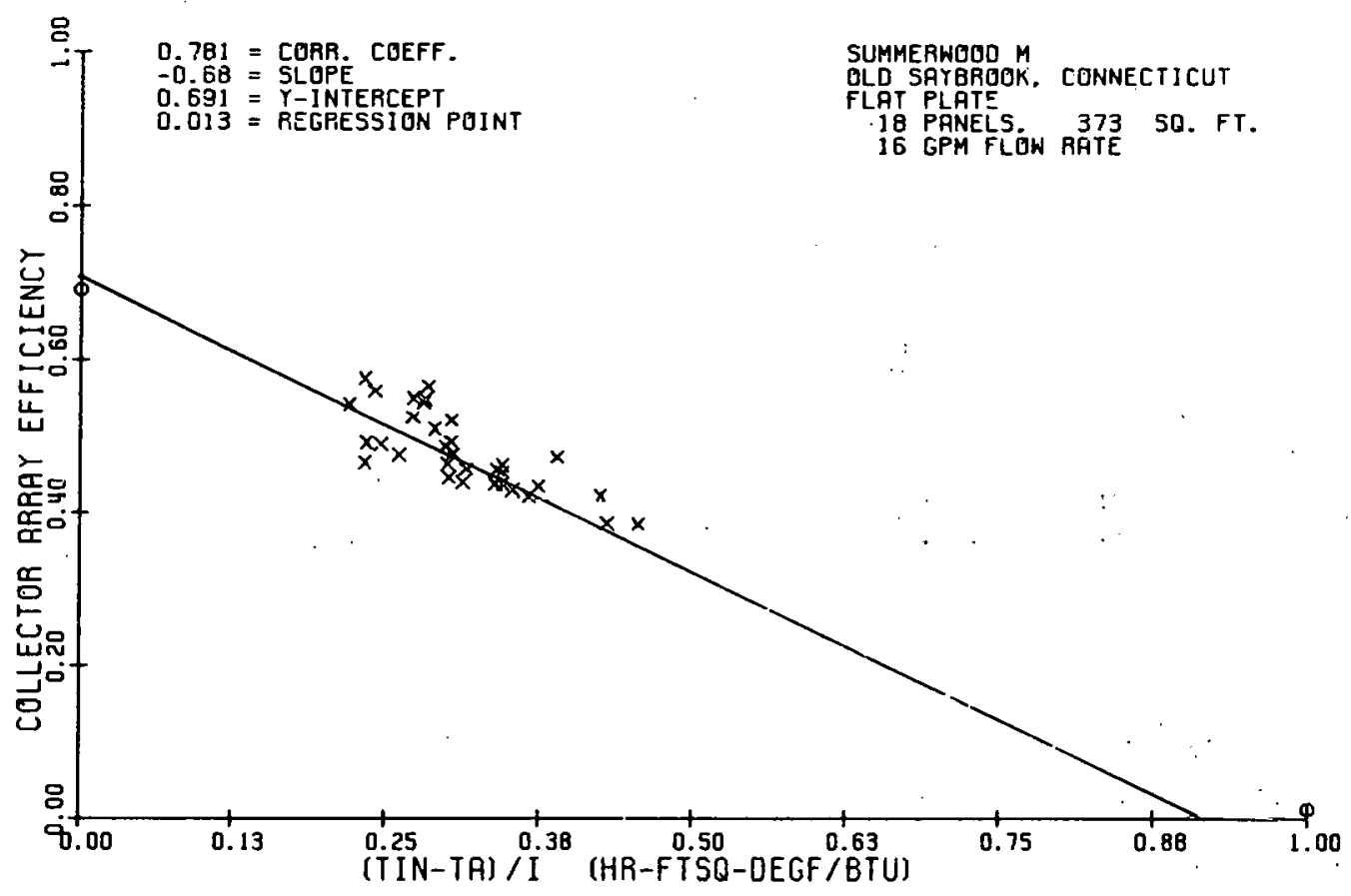

Figure 6b. Average Collector Efficiency Summerwood Associates, House M

May 1981

points are about $15 \%$ above the single-panel curve. The temperature sensors at the collectors and the storage inlet are in good agreement; the fault appears to be with the collector loop flow sensor, which must be reading too. high. This could also clear up problems with the measured storage loss based on a tank energy balance. The tank showed an energy loss even when it was cooler than its environment.

Through calculations of the storage energy balance on the hourly, daily, and monthly levels, and an assessment of the probable maximum energy collected based on the single panel curve, it was determined that the actual flow rate was $85 \%$ of the measured flow. (The measured flow was $17 \pm 0.5$ gallons per minute throughout the year.) This reduced flow was used for all tables in this report. The only data in this report reflecting the unreduced measured flow are the collector efficiency plots. Reducing the flow to $85 \%$ would lower each measured point to $85 \%$ of the value shown, bringing the measured points just under the single-panel curve. The storage energy losses are also more consistent when the reduced flow is used. (see the Storage Subsystem section). 
Collector subsystem efficiency has been computed from two bases. The first assumes that the efficiency is based upon all available solar energy. This approach makes the operation of the control system part of array efficiency. For example, energy may be available at the collector, but the collector fluid temperature is below the control minimum; thus, the energy is not collected. In this approach, collector array performance is described by comparing the net amount of collected solar energy to the incident solar energy. Energy that is deliberately or inadvertently rejected or lost from the collector subsystem is subtracted from the collected energy in computing the net value. The ratio of these two energies represents the collector array efficiency which may be expressed as

$$
\mathbf{n}_{c}=Q_{s} / Q_{i}
$$

where: $\quad n_{c}-$ collector array efficiency

$$
\begin{aligned}
& \mathbf{n}_{\mathbf{s}}=\text { collected solar energy } \\
& Q_{\mathbf{i}}=\text { incident solar pnergy }
\end{aligned}
$$

The monthly efficiency computed by this method is listed in the column entitled "Collector Subsystem Efficiency" in Table 4.

The second approach assumes the efficiency is based upon the incident solar energy only during the periods of collection.

Evaluation of collector efficiency using operational incident energy yields operational collector efficiency. Operational collector efficiency, nco, is computed as follows:

$$
\mathrm{n}_{\mathrm{co}}=\mathrm{Q}_{\mathrm{s}} / \mathrm{Q}_{\mathrm{Oi}}
$$

where: $\begin{aligned} & Q_{s}-\text { collected solar energy } \\ & Q_{n i}=\text { incident solar energy whilc the cullector pumpe opcrated }\end{aligned}$

The monthly efficiency computed by this method is listed in the column entitled "Collector Array Operational Efficiency" in Table 4. This latter efficiency term is not the same collector efficiency as represented by the ASHRAE Standard 93-77. Both operational collector efficiency and the ASHRAE collector efficiency are defined as the ratio of actual useful energy collected to solar energy incident upon the collector, and both use the same definition of collector area. However, the ASHRAE efficiency is determincd from instantaneous pvaluation undel tightly controlled, steady-state test conditions, while the operational collector efficiency is determined from the actual conditions of daily solar energy system operation. Measured monthly values of operational incident energy and computed values of operational rollector efficiency are presented in Table 4.

\subsection{STORAGE}

Thermal storage for the solar system is provided by a 600-gallon concrete water tank in the crawl space under the building, outside the conditioned space of the building. The tank is six feet long, five feet wide, and four feet high, insulated with two inches of polystyrene foam on the boṭtom, and 
four inches on the rest of the tank. The outside surface area of the tank is 161 square feet.

The performance of the storage subsystem is shown in Table 5 . (See Footnote 1.) During the reporting period, total solar energy delivered to storage was 43.43 million BTU. Forty percent of this energy, 16.94 million BTU, was lost. There were 4.05 million BTU going out of storage to the DHW subsystem, and 21.84 million BTU to the space heating subsystem. The storage losses shown in the table are calculated from the storage tank energy balance. The figures for energy into storage are all reduced to $85 \%$ of the measured value (see Collectior Subsystem section). The heat 1 oss coefficients are calculated from these storage losses using measured data for the tank environment temperature. This temperature varied from $45^{\circ} \mathrm{F}$ to over $90^{\circ} \mathrm{F}$, depending on the storage tank temperature and the season. The heat loss coefficient seems to have changed over the winter. It was measured in the $40^{\prime} \mathrm{s}$ in the summer and fall of 1980 , and in the $60^{\prime} \mathrm{s}$ in the spring of 1981.

The effective tank insulation was also studied by plotting the storage tank temperature decay over a 36-hour period when no energy was pumped into or out of the tank. The temperature declined from $153^{\circ} \mathrm{F}$ to $125^{\circ} \mathrm{F}$ indicating an average $R$ value of 3.5 . This value was obtained on several other days throughout the year. It is difficult to calculate this precisely, because the environment temperature of the tank changes rapidly in response to tank temperature changes, and temperatures at different locations near the tank may read differently by $10^{\circ}$ or $15^{\circ} \mathrm{F}$. The tank temperature also stratifies $10^{\circ}-$ $20^{\circ} \mathrm{F}$ after sitting for a few days with no pumps running.

1. Storage subsystem performance is evaluated by comparison of energy to storage, energy from storage, and the change in stored energy. The ratio of the sum of energy from storage and the change in stored energy, to the energy to storage is defined as storage efficiency. This relationship is expressed in the following equation:

$$
\text { STEFF }=(\text { STECH }+ \text { STEO }) / \text { STEI }
$$

Where: $\quad$ STEFF = Storage efficiency

STECH $=$ Change in stored energy .

STEO = Energy removed from storage

STEI = Energy added to storage

Effective storage heat loss coefficient (c) for the storage subsystem can be defined as follows:

$$
c=(\text { STEI-STEO-STECH }) /\left[\left(\mathrm{T}_{\mathrm{s}}-\mathrm{T}_{\mathrm{a}}\right) \times c\right] \frac{\mathrm{BTU}}{\mathrm{hr}{ }^{\circ \mathrm{F}}}
$$

Where: $\quad c=$ effective storage heat loss coefficient

$T_{S}=$ average storage temperature

$\mathrm{T}_{\mathrm{a}}=$ average ambient temperature in the vicinity of storage

$t=$ number of hours in the month 
Table 5. STORAGE PERFORMANCE

SUMMERWOOD ASSOCIATES, HOUSE M JUNE 1980 THROUGH MAY 1981

(All values in million BTU, unless otherwise indicated)

\begin{tabular}{|c|c|c|c|c|c|c|c|}
\hline MONTH & $\begin{array}{l}\text { ENERGY TO } \\
\text { STORAGE }\end{array}$ & $\begin{array}{l}\text { ENERGY FROM } \\
\text { STORAGE }\end{array}$ & $\begin{array}{l}\text { CHANGE IN } \\
\text { STURAGE ENERGY }\end{array}$ & $\begin{array}{l}\text { STORAGE } \\
\text { EFFICIENCY } \\
\text { (\%) }\end{array}$ & $\begin{array}{c}\text { AVERAGE } \\
\text { STORAGE } \\
\text { TEMPERATURE } \\
\left({ }^{\circ} \mathbf{F}\right)\end{array}$ & $\begin{array}{l}\text { EFFECTIVE } \\
\text { HEAT LOSS } \\
\text { COEFH ICIENT } \\
\left(\mathrm{BTU} / \mathrm{hr} \mathrm{r}^{\circ} \mathrm{F}\right)\end{array}$ & $\begin{array}{l}\text { LOSS FROM } \\
\text { STORAGE }\end{array}$ \\
\hline JN & 2.49 & 0.77 & -0.02 & 30 & 143 & 43.9 & 1.74 \\
\hline JUL & 3.15 & 0.84 & 0.13 & 31 & 152 & 47.3 & 2.18 \\
\hline AUG & 1.34 & 0.28 & -0.11 & 13 & 125 & 44.9 & 1.17 \\
\hline SEP & 0.43 & 0.09 & 0.07 & 37 & 90 & 37.5 & 0.27 \\
\hline ocr & 3.05 & 1.33 & -0.07 & $\{1$ & 138 & 48.1 & 1.79 \\
\hline NOV & $\quad 4.88$ & 4.56 & -0.01 & 93 & 90 & 22.9 & 0.33 \\
\hline DEC & 4.85 & 4.64 & -0.15 & 93 & 73 & 37.0 & 0.36 \\
\hline JAN & 5.13 & 4.47 & 0.14 & 90 & 67 & 58.3 & 0.52 \\
\hline FEB & 4.54 & 3.28 & 0.03 & 73 & 90 & 61.0 & 1.23 \\
\hline MAR & 6.09 & 4.22 & 0.41 & 76 & 88 & 65.11 & 1.46 \\
\hline APR & 3.48 & 0.75 & -0.13 & 18 & 133 & 66.2 & 2.86 \\
\hline MAY & 4.00 & 0.66 & 0.31 & 24 & 145 & 62.7 & 3.03 \\
\hline TOTAL & 43.43 & 25.89 & 0.60 & - & - & - & 16.94 \\
\hline AVERAGE & 3.62 & 2.16 & 0.05 & 61 & 111 & 47.2 & 1.46 \\
\hline
\end{tabular}

\subsection{DOMESTIC HOT WATER (DHW)}

The DHW subsystem performance for the Summerwood Associales, House M site for the repurting period is shown in Table 6 and by graphic illustration in Figure 7.

The DHW subsystem rèquired 3.46 million BTU of solar energy and 1.72 million BTU of auxiliary electrical energy to satisfy a hot water load of 5.18 million BTU. The solar fraction of this load was $67 \%$, with an operating energy of 0.42 million BTU. Losses frnm the DHW sulsystem were 2.50 million BTU. A da1ly average of 15 gallons of $\mathrm{DHW}$ was consumed at an average temperature of $128^{\circ} \mathrm{F}$.

The nIT subsyorem achieves a high solar fraction, close to $100 \%$, during the nonheating season of April to October. The DHW solar fraction was low in August and September only because the system was shut off for parts of those months. Energy savings are sma11 in the summer months, because the collector pump (1/3 HP) runs exclusively to support. DHW in thcse moulhs. The electrical encrgy savings for DHW heating by. the solar energy were partially offset by the relatively large amount of operating energy required to run the collector pump. To maintain the storage water at temperatures high enough to satisfy 
Table 6. DOMESTIC HOT WATER SUBSYSTEM

SUMMERWOOD ASSOCIATES, HOUSE M

JUNE 1980 THROUGH MAY 1981

(All values in million BTU, unless otherwise indicated)

\begin{tabular}{|c|c|c|c|c|c|c|c|c|c|c|c|}
\hline MONTH & $\begin{array}{l}\text { HOT } \\
\text { WATER } \\
\text { LOAD }\end{array}$ & $\begin{array}{l}\text { SOLAR } \\
\text { FRACTION } \\
\text { OF LOAD } \\
\text { (\%) }\end{array}$ & $\begin{array}{c}\text { HOT } \\
\text { WATER } \\
\text { DEMAND }\end{array}$ & $\begin{array}{l}\text { SOLAR } \\
\text { FRACTION } \\
\text { OF DEMAND } \\
(\%)\end{array}$ & $\begin{array}{l}\text { SOLAR } \\
\text { ENERGY } \\
\text { USED }\end{array}$ & $\begin{array}{c}\text { AUX } \\
\text { THERMAL } \\
\text { USED }\end{array}$ & $\begin{array}{l}\text { AUX } \\
\text { ELECT } \\
\text { FUEL }\end{array}$ & $\begin{array}{l}\text { OPERATING } \\
\text { ENERGY }\end{array}$ & $\begin{array}{l}\text { SUP. } \\
\text { WATER } \\
\text { TEMP } \\
\left({ }^{\circ} \mathrm{F}\right)\end{array}$ & $\begin{array}{l}\text { HOT } \\
\text { WATER } \\
\text { TEMP } \\
\left({ }^{\circ} \mathrm{F}\right)\end{array}$ & $\begin{array}{c}\text { HOT WATER } \\
\text { CONSUMPTION } \\
\text { (GAL) }\end{array}$ \\
\hline JUN & 0.63 & 98 & 0.34 & 90 & 0.62 & 0.01 & 0.01 & 0.06 & 70 & 135 & 528 \\
\hline JUL & 0.66 & 98 & 0.36 & 96 & 0.65 & 0.01 & 0.01 & 0.07 & 74 & 134 & 584 \\
\hline AUG & 0.22 & 46 & 0.12 & 57 & 0.10 & 0.12 & 0.12 & 0.03 & 75 & 138 & 221 \\
\hline SEP & 0.40 & 21 & 0.25 & 12 & 0.08 & 0.32 & 0.32 & 0.01 & 70 & 128 & 518 \\
\hline OCT & 0.38 & 96 & 0.12 & 93 & 0.36 & 0.02 & 0.02 & 0.04 & 67 & 131 & 224 \\
\hline NOV & 0.47 & 59 & 0.33 & 58 & 0.28 & 0.19 & 0.19 & 0.02 & 62 & 128 & 597 \\
\hline DEC & 0.68 & 29 & 0.50 & 33 & 0.20 & 0.48 & 0.48 & 0.01 & 55 & 133 & 759 \\
\hline JAN & 0.43 & 26 & 0.28 & $\star$ & 0.11 & .0 .32 & 0.32 & 0.04 & 51 & 129 & 435 \\
\hline FEB & 0.33 & 39 & 0.18 & * & 0.13 & 0.20 & 0.20 & 0.04 & 52 & 111 & 352 \\
\hline MAR & 0.29 & 82 & 0.24 & 82 & 0.24 & 0.05 & 0.05 & 0.02 & 53 & 108 & 522 \\
\hline APR & 0.26 & 100 & 0.11 & 100 & 0.26 & 0.00 & 0.00 & 0.03 & 58 & 129 & 188 \\
\hline MAY & 0.43 & 99 & 0.27 & 100 & 0.43 & 0.00 & 0.00 & 0.05 & 62 & 136 & 431 \\
\hline TOTAL & 5.18 & - & 3.10 & - & 3.46 & 1.72 & 1.72 & 0.42 & - & - & 5,359 \\
\hline AVERAGE & 0.43 & 67 & 0.26 & 64 & 0.27 & 0.14 & 0.14 & 0.04 & 62 & 128 & 447 \\
\hline
\end{tabular}

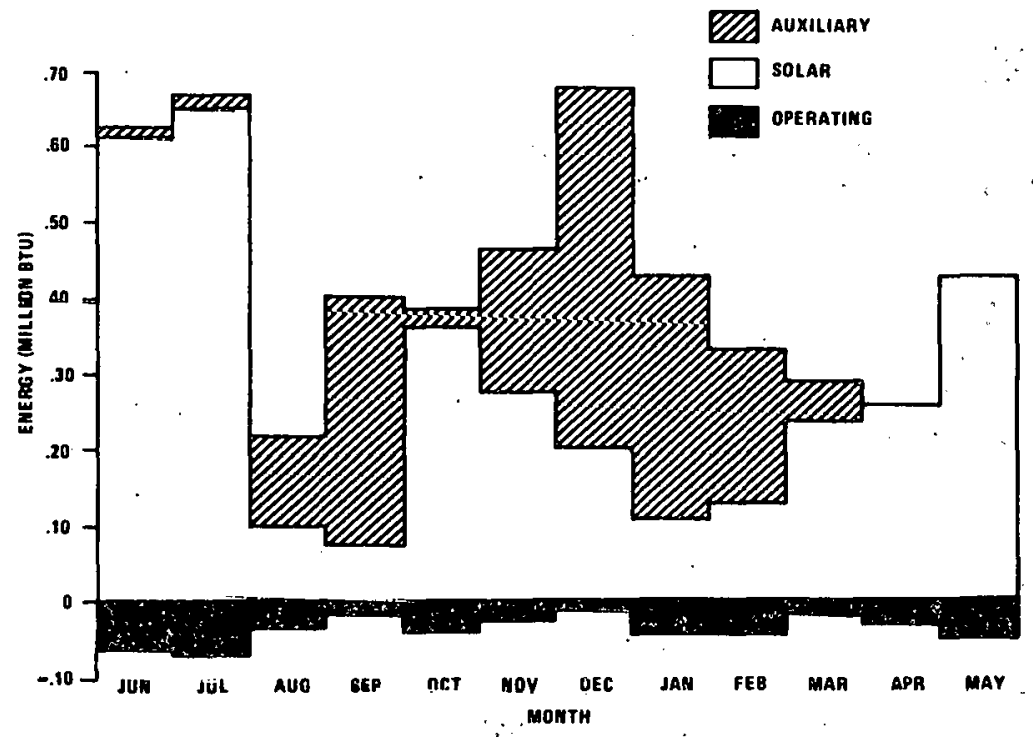

OPERATIMG ENERGY FOR THE SYSTEM IS CONSIDERED A SYSTEM PENALTY ANO IS PLOTTEO AS A MEGATIVE VALUE BELOW THE ORIGIW.

Figure 7. DHW Subsystem Performance

Summerwood Associates, House M.

June 1980 through May 1981 
the DHW load, the collector pump had to operate long enough to deliver enough solar energy to storage to offset the high storage losses. Thus, much operating energy was consumed. From April to October, 19.35 million BTU were co1lected to support a system load of $4.43 \mathrm{million}$ BTU. The operating energy for the DHW preheat loop is not large, as the pump is only $1 / 20 \mathrm{HP}$. It runs four hours per day on the average, but the energy delivered to the DHW tank is usually small in the last two hours. Reducing the storage losses and perhaps lowering the water level in the storage tank in the summer would increase energy savings.

In the heating months the solar fraction is much lower because of the use of solar energy for space heating which keeps the storage temperature lower.

\subsection{SPACE HEATING}

The space heating performance for the Summerwood Associates, House M site for the reporting period is shown in Tables 7 and 8 and presented graphically in Figure 8 .

Table 7. SPACE HEATING SUBSYSTEM I

SUMMERWOOD ASSOCIATES, HOUSE M

JUNE 1980 THROUGH MAY 1981

(All values in million BTU, unless otherwise indicated)

\begin{tabular}{cccccccc} 
MONTH & $\begin{array}{c}\text { SPACE } \\
\text { HEATING } \\
\text { LOAD }\end{array}$ & $\begin{array}{c}\text { CONTROLLED } \\
\text { DFI_IVERED } \\
\text { ENERGY }\end{array}$ & $\begin{array}{c}\text { TOTAL } \\
\text { SOLAR } \\
\text { ENERGY } \\
\text { USED }\end{array}$ & $\begin{array}{c}\text { TOTAL } \\
\text { AUXILIARY } \\
\text { THERMAL USED }\end{array}$ & $\begin{array}{c}\text { SOLAR } \\
\text { FRACTION } \\
\text { LOAD } \\
(\%)\end{array}$ & $\begin{array}{c}\text { BLDG } \\
\text { TEMP } \\
\left({ }^{\circ} F\right)\end{array}$ & $\begin{array}{r}\text { AMB } \\
\text { TEMP } \\
\left({ }^{\circ} \mathrm{F}\right)\end{array}$ \\
\hline JUN & 0.10 & 0.10 & 0.10 & 0.00 & 100 & 73 & 66 \\
JUL & 0.00 & 0.00 & 0.00 & 0.00 & - & 75 & 75 \\
AUG & 0.00 & 0.00 & 0.00 & 0.00 & - & 78 & 75 \\
SEP & 0.00 & 0.00 & 0.00 & 0.00 & - & 74 & 67 \\
OCT & 0.77 & 0.72 & 0.62 & 0.01 & 80 & 68 & 52 \\
NOV & 6.14 & 5.76 & 4.17 & 0.10 & 68 & 68 & 42 \\
DEC & 9.52 & 8.84 & 4.52 & 4.18 & 48 & 65 & 29 \\
JAN & 11.46 & 10.69 & 4.55 & 5.10 & 40 & 61 & 22 \\
FEB & 4.54 & 4.11 & 3.32 & 0.79 & 72 & 61 & 36 \\
MAR & 5.40 & 4.72 & 3.90 & 0.87 & 72 & 63 & 38 \\
APR & 0.44 & 0.39 & 0.43 & 0.00 & 98 & 64 & 50 \\
MAY & 0.14 & 0.13 & 0.14 & 0.00 & 96 & 71 & 59 \\
\hline TOTAL & $38.51 *$ & 35.46 & 21.74 & 11.05 & - & - & - \\
AVERAGE & 3.21 & 2.96 & 1.81 & 0.92 & 56 & 64 & 51
\end{tabular}

*Includes losses from solar and auxiliary heating equipment which contribute to the space heating load. 
Table 8. SPACE HEATING SUBSYSTEM II

SUMMERWOOD ASSOCIATES, HOUSE M

JUNE 1980 THROUGH MAY 1981

(All values in million BTU, unless otherwise indicated)

\begin{tabular}{|c|c|c|c|c|c|c|c|}
\hline MONTH & $\begin{array}{c}\text { SPACE } \\
\text { HEATING } \\
\text { LOAD }\end{array}$ & $\begin{array}{l}\text { UEASURED } \\
\text { SOLAR ENERGY } \\
\text { USED }\end{array}$ & $\begin{array}{l}\text { SOLAR ENERGY } \\
\text { LOSSES } \\
\text { TO LOAD }\end{array}$ & $\begin{array}{l}\text { TOTAL } \\
\text { OPERATING } \\
\text { ENERGY }\end{array}$ & $\begin{array}{l}\text { SOLAR } \\
\text { SPECIFIC } \\
\text { OPERATING } \\
\text { ENERGY }\end{array}$ & $\begin{array}{l}\text { AUXILIARY } \\
\text { ELECT } \\
\text { FUEL }\end{array}$ & $\begin{array}{l}\text { HEATING } \\
\text { DEGREE } \\
\text { DAYS }\end{array}$ \\
\hline תN & 0.10 & 0.10 & 0.00 & 0.02 & 0.00 & 0.00 & 52 \\
\hline JUL & 0.00 & 0.00 & 0.00 & 0.00 & 0.00 & 0.00 & 0 \\
\hline AUG & 0.00 & 0.00 & 0.00 & 0.01 & 0.00 & 0.00 & 0 \\
\hline SEP & 0.00 & 0.00 & 0.00 & 0.00 & 0.00 & 0.00 & 68 \\
\hline oCT & 0.77 & 0.58 & 0.04 & 0.06 & 0.01 & 0.01 & 360 \\
\hline nov & 6.14 & 3.89 & 0.28 & 0.50 & 0.10 & 0.11 & 677 \\
\hline DEC & 9.52 & 4.50 & 0.02 & 1.13 & 0.25 & 4.62 & 1,109 \\
\hline JAN & 11.46 & 4.49 & 0.06 & 0.95 & 0.05 & 5.62 & 1,325 \\
\hline FEB & 4.54 & 3.18 & 0.13 & 0.48 & 0.10 & 0.99 & 810 \\
\hline MAR & 5.40 & 3.67 & 0.23 & 0.54 & 0.07 & 1.21 & 812 \\
\hline APR & 0.44 & 0.39 & 0.04 & 0.03 & 0.01 & 0.00 & 442 \\
\hline MAY & 0.14 & 0.13 & 0.01 & 0.01 & 0.00 & 0.00 & 187 \\
\hline TOTAL & 38.51 & 20.93 & 0.81 & 3.73 & 0.59 & 12.56 & 5,842 \\
\hline AVERAGE & 3.21 & 1.74 & 0.07 & 0.31 & 0.05 & 1.05 & - \\
\hline
\end{tabular}

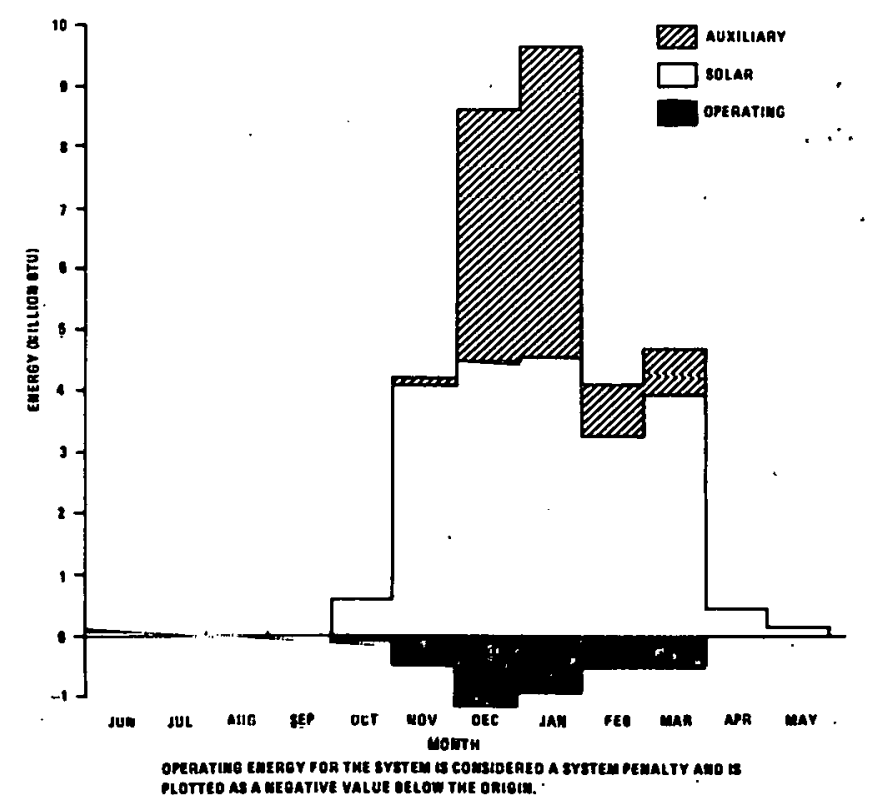

Figure 8. Space Heating Subsystem

Summerwood Associates, House M June 1980 through May 1981 
The space heating load of 38.51 million BTU was satisfied by 21.74 million BTU of solar energy and 11.05 million BTU of auxiliary energy. The solar fraction of this load was $56 \%$ with an operating energy expense of 0.59 million BTU. The solar energy supplied to the heat pump allowed it to operate at a seasonal COP of 3.5 .

The electrical energy savings (November through March) were 11.88 million BTU. The average building temperature for the heating season was $64^{\circ} \mathrm{F}$.

The operation of the heating system is as follows. When there is a demand for heat and storage temperature is above $85^{\circ} \mathrm{F}$, direct solar heating is activated. If the building temperature continues to drop, one-half of the electric strip heaters come on. If the storage tank is above $40^{\circ} \mathrm{F}$ but below $85^{\circ} \mathrm{F}$, the heat pump is used in solar-assisted mode. If the storage temperature is below $40^{\circ} \mathrm{F}$ and air temperature is above $10^{\circ} \mathrm{F}$, the heat pump is used in air-to-air mode. The electric duct heaters are used alone if the outdoor temperature drups belnw $10^{\circ} \mathrm{F}$ and storage temperature 13 below $40^{\circ} \mathrm{F}$.

During the heating season (November through March) the heat pump operating in solar-assisted mode supplied just over half $(51 \%)$ of the controlled delivered energy (CDE). The heat pump in air-to-air mode supplied only two percent of $\mathrm{CDE}$, and direct solar and the electric resistance heaters each supplied just under one quarter of the CDE. The electric resistance heaters showed significant use only in December and January, which were much colder than normal.

The space heating subsystem at Summerwood Associates, House M performed well, achieving a solar fraction of $56 \%$, compared to the designers' expectation of 78\%. The solar fraction is good because the winter from October through January was very much colder than normal. The control system always worked as designed, and the heat pump had a good coefficient of performance.

The biggest fault of the heating system is that it is undersized and in very cold weather (around $0^{\circ} \mathrm{F}$ ) the house temperature was chilly, in the $50^{\prime} \mathrm{s}$.

Building load analysis by the UAC method is also included in Table 9. This method is designed to calculate the equipment heating load of the building, i.e., the amount of energy delivered to the building by the heating equipment, including thermal losses from the space heating equipment to the building. The overall agreement is good, although the calculated load is ton large in the warmer months and too small, in the colder months. The calculations are based on a building temperature of $68^{\circ} \mathrm{F}-70^{\circ} \mathrm{F}$, which was not the case in the colder months. Also, there are significant passive gains through the southfacing windows into the space in which the building temperature sensor is located. Passive snlar heating contributions are not fully monitored al this site. 


\section{Table 9. DESIGN HEATING LOAD BY UA $x$ Cd METHOD}

SUMMERWOOD ASSOCIATES, HOUSE M JUNE 1980 THROUGH MAY 1981

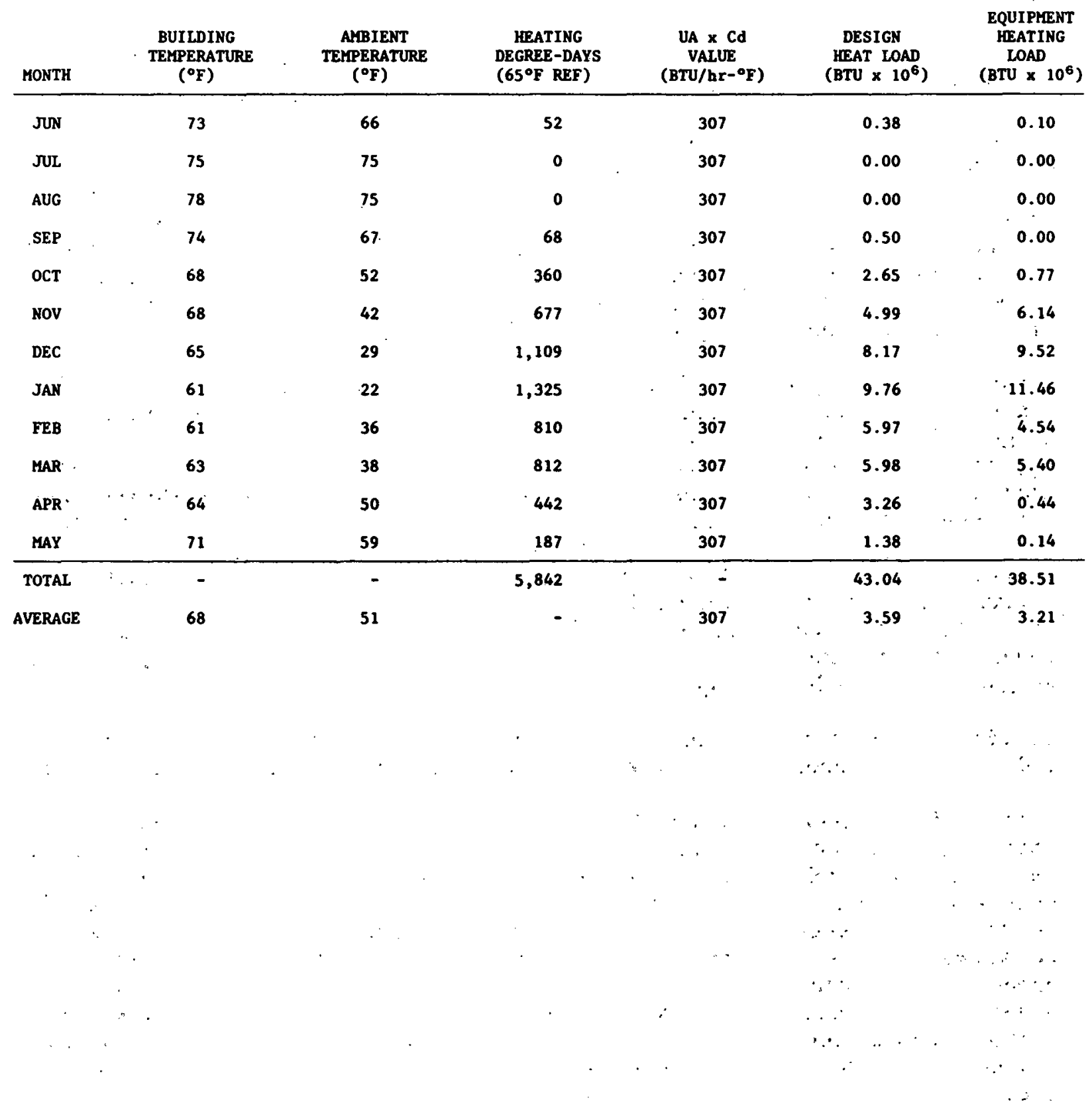




\section{SECTION 3}

\section{SOLAR OPERATING ENERGY}

Measured monthly values of the Summerwood Associates, House M solar energy system and subsystem operating energy for the report period are presented in Table 10. A total 3.78 million BTU of operating energy were consumed by the solar system during the reporting period.

Total system operating energy for Summerwood Associates, House $M$ is the electrical energy required to support the collector, storage, space heating, and domestic hot water subsystems without affecting their thermal states.

Table 10. SOLAR OPERATING ENERGY

SUMMERWOOD ASSOCIATES, HOUSE M

JUNE 1980 THROUGH MAY 1981

(All values in million BTU)

\begin{tabular}{ccccc} 
MONTH & $\begin{array}{c}\text { ECSS } \\
\text { OPERATING ENERGY }\end{array}$ & $\begin{array}{c}\text { DHW } \\
\text { OPERATING } \\
\text { ENERGY }\end{array}$ & $\begin{array}{c}\text { SHS } \\
\text { OPERATING } \\
\text { ENERGY }\end{array}$ & $\begin{array}{c}\text { TOTAL SOLAR } \\
\text { OPERATING ENERGY }\end{array}$ \\
\hline JUN & 0.25 & 0.06 & 0.00 & 0.31 \\
JUL & 0.30 & 0.07 & 0.00 & 0.37 \\
AUG & 0.11 & 0.03 & 0.00 & $\cdots$ \\
SEP & 0.02 & 0.01 & 0.00 & 0.14 \\
OCT & 0.23 & 0.04 & 0.01 & 0.28 \\
NOV & 0.27 & 0.02 & 0.10 & 0.39 \\
DEC & 0.27 & 0.01 & 0.25 & 0.53 \\
JAN & 0.28 & 0.04 & 0.05 & 0.37 \\
FEB & 0.23 & 0.04 & 0.10 & 0.37 \\
MAR & 0.31 & 0.02 & 0.07 & 0.40 \\
APR & 0.22 & 0.03 & 0.01 & 0.33 \\
MAY & 0.28 & 0.05 & 0.00 &. \\
\hline TOTAL & 2.77 & 0.42 & 0.59 & \\
AVERAGE & 0.23 & 0.04 & 0.05 & 0.38
\end{tabular}

The components which use operating energy are:

P1 - ECSS circulation pump (1/3 HP Marlow Centrifugal pump)

P2 - Heatịng load pump (two $1 / 12$ HP in series Grundfos circulators)

P3 - DHW preheat pump (1/20 HP Grundfos circulator)

Distribution blower - $1 / 6 \mathrm{HP}$

Heat pump outside fan 
DHW operating energy, though not large, was twice as large as it needed to be, because the duration of the preheat loop cycle was about twice as long as optimal, and no energy was delivered to the DHW tank in the second half of the cycle.

Space heating and ECSS operating energies were satisfactory.

In the summer, when the load is DHW only, the operating energy for the collectors is a significant portion of the possible energy savings. This expense could be lessened by lowering the level of the storage tank fluid, so the collectors could get the tank hot in less time, with less operating energy. 


\section{SECTION 4}

\section{ENERGY SAVINGS}

Energy savings for this site for the reporting period, June 1980 through May 1981 , are presented in Table 11.

Table 11.' ENERGY SAVINGS

SUMMERWOOD ASSOCIATES, HOUSE M

JUNE 1980 THROUGH MAY 1981

(All values in million BTU)

\begin{tabular}{|c|c|c|c|c|c|}
\hline \multirow[b]{2}{*}{ MONTH } & \multirow{2}{*}{$\begin{array}{l}\text { SOLAR } \\
\text { ENERGY USED }\end{array}$} & \multirow{2}{*}{$\begin{array}{c}\begin{array}{c}\text { SPACE } \\
\text { HEATING }\end{array} \\
\text { ELECTRICAL }\end{array}$} & \multirow{2}{*}{$\begin{array}{r}\text { DOMESTIC } \\
\text { HOT WATER } \\
\text { ELECTRICAL }\end{array}$} & \multirow{2}{*}{$\begin{array}{c}\text { ECSS } \\
\text { OPERATING } \\
\text { ENERGY } \\
\text { SOLAR UNIQUE }\end{array}$} & \multirow{2}{*}{$\begin{array}{l}\text { NET ENERGY } \\
\text { SAVINGS } \\
\text { ELECTRICAI }\end{array}$} \\
\hline & & & & & \\
\hline JN & 0.72 & 0.08 & 0.57 & 0.25 & 0.39 \\
\hline ЛL & 0.65 & 0.00 & 0.58 & 0.30 & 0.28 \\
\hline AUG & 0.10 & 0.00 & 0.07 & 0.11 & -0.04 \\
\hline SEP & 0.08 & 0.00 & 0.08 & 0.02 & 0.06 \\
\hline OCT & 0.98 & 0.31 & 0.32 & 0.23 & 0.40 \\
\hline NOV & 4.45 & 2.10 & 0.26 & 0.27 & 2.09 \\
\hline DEC & 4.72 & 3.29 & 0.19 & 0.27 & 3.21 \\
\hline JAN & 4.66 & 3.54 & 0.07 & 0.28 & 3.32 \\
\hline FEB & 3.44 & 0.86 & 0.09 & 0.23 & 0.72 \\
\hline MAR & 4.14 & 1.40 & 0.22 & 0.31 & 0.31 \\
\hline APR & 0.69 & 0.24 & 0.23 & 0.22 & 0.26 \\
\hline MAY & 0.57 & 0.06 & 0.38 & 0.28 & 0.17 \\
\hline TOTAL & 25.20 & 11.88 & 3.06 & 2.77 & 12.17 \\
\hline AVERAGE & 2.10 & 0.99 & 0.26 & 0.23 & 1.01 \\
\hline
\end{tabular}

For this one year period, the total savings were 12.17 million BTU, for a monthly average of 1.01 million BTU. This is equivalent to $3,563 \mathrm{kwh}$ of electric power. An electrical energy expense of 3.78 million BTU was incurred during the reporting period for the operation of solar energy components.

Solar energy system savings are realized whenever energy provided by the solar energy system is used to meet syctem demands which would otherwise be met by auxiliary energy sources. The operating energy required to transport solar energy from the collector to storage is subtracted from the solar energy contribution to the loads to determine net savings. 
The auxiliary sources at the Summerwood Associates, House $M$ site consist of electric resistance heaters in the DHW tanks and in the space heating ducts. These units are considered to be $100 \%$ efficient for computational purposes. The efficiency of the heat pump is calculated as a function of the temperature of the evaporator source (water or air).

Savings were good in the winter, negligible in the summer. Restoring the storage tank insulation back to design standards would improve the savings, particularly in the nonheating months when the storage tank is hot. (See Storage Subsystem discussion). If the water level of the storage tank were lowered in the summer to about 300 gallons, the tank could reach the DHW set point with less use of the collector pump, which would also improve savings. 
Summerwood Associates, House $M$ is located in 0ld Saybrook, Connecticut at 41 degrees $N$ latitude and 72 degrees $W$ longitude.

Monthly values of the total solar energy incident in the plane of the collector array and the average outdoor temperature measured at the site during the reporting period are presented in Table 12. Also presented in the table are the corresponding long-term average monthly values of the measured weather parameters. These long-term average weather data were obtained from nearby representative National Weather Service and SOLMET meteorological stations. The long-term average insolation values are total global horizontal radiation converted to collector tilt and azimuth orientation through a TRNSYS type radiation processor.

Table 12. WEATHER CONDITIONS

SUMMERWOOD ASSOCIATES, HOUSE M JUNE 1980 THROUGH MAY 1981

\begin{tabular}{|c|c|c|c|c|c|c|}
\hline \multirow[b]{2}{*}{ MONTH } & \multicolumn{2}{|c|}{$\begin{array}{l}\text { DAILY INCIDENT SOLAR } \\
\text { ENERGY PER UNIT AREA } \\
\text { (BTU/FT }{ }^{2} \text {-DAY) }\end{array}$} & \multicolumn{2}{|c|}{$\begin{array}{c}\text { AMBIENT } \\
\text { TEMPERATURE }\left({ }^{\circ} \mathrm{F}\right)\end{array}$} & \multicolumn{2}{|c|}{$\begin{array}{c}\text { HEATING } \\
\text { DEGREE-DAYS }\end{array}$} \\
\hline & MEASURED & $\begin{array}{c}\text { LONG-TERM } \\
\text { AVERAGE }\end{array}$ & MEASURED & $\begin{array}{c}\text { LONG-TERM } \\
\text { AVERAGE }\end{array}$ & MEASURED & $\begin{array}{l}\text { LONG-TERM } \\
\text { AVERAGE }\end{array}$ \\
\hline JUN & 1,336 & 1,423 & 66 & 68 & 52 & 24 \\
\hline JUL & 1,515 & 1,431 & 75 & 74 & 0 & 0 \\
\hline AUG & 1,377 & 1,428 & 75 & 73 & 0 & 0 \\
\hline SEP & 1,560 & 1,394 & 67 & 67 & 68 & 42 \\
\hline OCT & 1,127 & 1,319 & 52 & 57 & 360 & 261 \\
\hline NOV & 1,059 & 957 & 42 & 46 & 677 & 570 \\
\hline DEC & 990 & 810 & 29 & 34 & 1,109 & 967 \\
\hline JAN & 1.057 & 952 & 22 & 30 & 1,325 & 1,079 \\
\hline FEB & 1.066 & 1,146 & 36 & 31 & 810 & 955 \\
\hline MAR & 1,357 & 1,300 & 38 & 38 & 812 & 840 \\
\hline APR & 1,341 & 1,399 & 50 & 48 & 442 & 498 \\
\hline MAY & 1,478 & 1,421 & 59 & 58 & 187 & 225 \\
\hline TOTAL & 15,263 & 14,980 & - & - & 5,842 & 5,461 \\
\hline AVERAGE & 1,272 & 1,248 & 51 & 52 & - & - \\
\hline
\end{tabular}

During the period from June 1980 through May 1981, the average daily total incident solar radiation on the collector array was 1,272 BTU per square foot per day. This radiation was above the estimated average daily solar radiation for this geographical area during the reporting period of 1,248 BTU per square 
foot per day for a plane facing 12 degrees West of South with a tilt of 50 degrees to the horizontal. During the period, the highest monthly average insolation was 1,560 BTU per square foot per day during September. The average ambient temperature during the reporting period was $51^{\circ} \mathrm{F}$ as compared with the long-term annual average of $52^{\circ} \mathrm{F}$. The highest monthly average ambient temperature was $75^{\circ} \mathrm{F}$ during July and August, and the lowest monthly average ambient temperature was $22^{\circ} \mathrm{F}$ during January. The number of heating degreedays for the period (based on a $65^{\circ} \mathrm{F}$ reference) was 5,842 as compared with the long-term average of 5,461. The range of heating degree-days was from a high of 1,325 during January to a low of zero during July and August. The lowest temperature was $-12^{\circ} \mathrm{F}$ on December 25 . The warmest was $102^{\circ} \mathrm{F}$ on July 21 . The four-month period from October through January was very much colder than normal.

Extraterrestrial radiation values are computed (see Footnote 1) and given in the table below for each month. The ratio of total insolation on a tilted surfare to extraterrestilial radiation on a parallel surface is called the clearness index.

This parameter quantifies the effects of cloudiness and atmospheric transmission on the insolation received at the earth's surface. The clearness index ranged from a high of $56 \%$ during July to a low of $33 \%$ during February.

\begin{tabular}{|c|c|c|c|c|c|c|c|c|c|c|c|c|}
\hline MONTH & JUN & JUL & AUG & SEP & OCT & Nov & DEC & JAN & FEB & MAR & APR & MAY \\
\hline $\begin{array}{l}\text { EXTRATERRESTRIAL } \\
\text { INSOLATION }\end{array}$ & 2,656 & 2,718 & 2,963 & 3,194 & 3,228 & 3,059 & 2,928 & 3,018 & 3,218 & 3.270 & 3,094 & 2,814 \\
\hline$\frac{\text { TTL INS }}{\text { EXT }}$ TNS $(\%)$ & 50 & 56 & $\Delta 6$ & 19 & 35 & 35 & 34 & 35 & \{\} & 41 & 43 & כ5 \\
\hline
\end{tabular}

Fú a more complete: set of meteorological data see Appendix F, which contains daily average values for the monthe of the repurting period.

1. Computation method given in "TRNSYS, a Transient Simulation Program," Engineering Experiment Station Report \#38, Solar Energy Laboratory, University of Wisconsin, Madison. 
*1. National Solar Data Network, Department of Energy, prepared under Contract Number DE-AC01-79CS30027, Vitro Laboratories, Silver Spring, Maryland, January 1980 .

2. J. T. Smok, V. S. Sohoni, J. M. Nash, "Processing of Instrumented Data for the National Solar Heating and Cooling Demonstration Program," Conference on Performance Monitoring Techniques for Evaluation of Solar Heating and Cooling Systems, Washington, D.C., April 1978.

3. E. Streed, et al, Thermal Data Requirements and Performance Evaluation Procedures for the National Solar Heating and Cooling Demonstration Program, NBSIR-76-1137, National Bureau of Standards, Washington, D.C., 1976 .

*4. Mears, J. C., Reference Monthly Environmental Data for Systems in the National Solar Data Network. Department of Energy report SOLAR/0019-79/ 36. Washington, D.C., 1979.

5. ASHRAE Standard 93-77, Methods of Testing to Determine the Thermal Performance of Solar Collectors, The American Society of Heating, Refrigeration and Air Conditioning Engineers, Inc., New York, N.Y., 1977.

* *6. ASHRAE Standard 94-77, Methods of Testing Thermal Storage Devices Based on Thermal Performance, The American Society of Heating, Refrigeration and Air Conditioning Engineers, Inc., New York, N.Y., 1977.

*6A. User's Guide to Monthly Performance Reports, June 1980, SOLAR/0004-80/18, Vitro Laboratories, Silver Spring, Maryland.

*6B. Instrumentation Installation Guidelines March 1981, Parts 1, 2, and 3, SOLAR/0001-81/15, Vitro Laboratories, Silver Spring, Maryland.

*7. Monthly Performance Report, Summerwood Associates, House M, June '1980, SOLAR/1102-80/06, Vitro Laboratories, Silver Spring, Maryland.

*8. Monthly Performance Report, Summerwood Associates, House M, July 1980, SOLAR/1102-80/07, Vitro Laboratories, Silver Spring, Maryland.

*9. Monthly Performance Report, Summerwood Associates, House M, November 1980, SOLAR/1102-80/11, Vitro Laboratories, Silver Spring, Maryland.

*10. Monthly Performance Report, Summerwood Associates, House M, December 1980, SOLAR/1102-80/12, Vitro Laboratories, Silver Spring, Maryland.

₹ Copies of these reports may be obtained from Technical Information Center, P.0. Box 62, Oak Ridge, Tennessee 37830 .

**Note: Reference [6] only used if the heat transfer coefficient discussion in Section 5.3.1.2 applies. 
APPENDIX A

SYSTEM DESCRIPTION

The Summerwood Associates site is a cluster of condominiums overlooking Long Island Sound. Two adjacent units are instrumented: a Madison model designated Summerwood $M$, and a Guilford model designated Summerwood G. The Summerwood $M$ site is described in this report.

The Summerwood M site is a rowhouse residence in old Saybrook, Connecticut. The home has approximately 1,375 square feet of conditioned space. Solar energy is used for space heating and preheating domestic hot water (DHW). The solar energy system has an array of flat-plate collectors with a gross area of 378 square feet. The array faces 12 degrees West of South at an angle of 50 degrees to the horizontal. Water is the transfer medium that delivers solar energy from the collector array to storage and to the space heating and DHW loads. Draindown provides collector freeze protection. Solar energy is stored in a 600-gallon poured-concrete insulated tank located in a crawl space. Solar heated water is supplied to a liquid-to-air heat exchanger within the space heating duct and to a heat pump for water-to-air operation. A closed heat transfer loop between the solar storage tank and a 120-gallon DHW tank provides solar energy to the DHW supply. When solar energy is insufficient to satisfy the entire space heating load, the heat pump operates in its water-to-air mode, extracting heat from the solar-heated water. When the storage tank temperature falls below $40^{\circ} \mathrm{F}$, the heat pump automatically disconnects from the solar-heated water supply and operates in an air-to-air mode using an outdoor evaporator. An electric heater in the space heating duct provides auxiliary energy for space heating in conjunction with both solar and conventional heating modes. An electrical heating element in the DHW tank provides auxiliary energy for water heating.

The manufacturers of major solar system equipment and components are listed below.

Equipment/Components

Collector

Solar storage tank

Solar storage tank insulation

Air-handling system, including blowers, heat exchangers, heat pump and electrical résistance heater

Domestic water heater

Control mode selector
Manufacturer

Sunworks

Wormser Scientific Corporation

Dow Chemical Co.

Friedrich Air Conditioniug and Refrigeration Co.

Vaughn Corporation

Johne on Controls
Model No. or Type

Solcctor IM LC

Site-built concrete

Polystyrene Styrofoam G

Climatc Master $\mathrm{V}-22$ 12AW
E-120SNR-0

$147-1-2-3$ 
The system, shown schematically in Figure A-1, has four modes of solar operation.

Mode 1 - Collector-to-Storage - This mode activates when collector temperature exceeds the storage temperature by $15^{\circ} \mathrm{F}$ and terminates when a temperature difference of $2^{\circ} \mathrm{F}$ is reached. Collector loop pump $P 1$ is operated in this mode.

Mode 2 - Storage-to-Space Heating - Direct Solar Mode - This mode activates when there is a demand for space heating and solar storage temperature is above $85^{\circ} \mathrm{F}$. Circulating pump $P 2$ and the air-handling subsystem blower are operated in this mode.

Mode 3 - Storage-to-Space Heating - Solar-Assisted Heat Pump Mode - This mode activates when there is a demand for space heating and the sular storage temperature is less than $85^{\circ} \mathrm{F}$ and greater than $40^{\circ} \mathrm{F}$. Circulating pump $\mathrm{P2}$, the air-handling subsystem blower, and the heat pump are operated in this mode.

Mode 4 - Storage-to-DHW - This mode activates when the temperature difference between colar storage and the DHW tank exceedo $15^{\circ} \mathrm{F}$ and terminates when the temperature difference drops below $6^{\circ} \mathrm{F}$. Pump P3 is operated in this mode.

\section{SUBSYSTEMS}

Collector - The solar collectors at Summerwood Associates, House M are Sunworks Solectors, manufactured by Sunworks, Inc., of Guilford, Connecticut. A total of 18 collectors are used - three rows of six collectors each. The collectors are three feet by seven feet, giving a gross collector area of 378 square feet. The collectors are on the roof of the building, oriented 12 degrees West of South, at a slope of 50 degrees from the horizontal.

The collectors have a single 3/16-inch low iron glass cover with $92 \%$ solar transmittance. The ahsorber is coppcr sheet with a selective black surface manufactured by Finthone. The ourface lias an absorptivity of 0.90 and an emissivity of 0.12 . Fluid passages are one-fourth inch copper tubes spaced 16 inches apart with a one-inch copper manifold. The tubes are soft soldered to the absorber sheet: Insulation behind the absorber is two and one-half inch fiberglass. The transfer fluid used is water. A11 collectors are plumbed in parallel. When the collector pump turns off, a11 fluid draius back 1nco the storage tank.

Storage - Solar energy storage is provided by a 600-gallon concrete site-built tank. The tank is in an unheated crawl space beneath the house. The tank has an EPDM membrane liner. Insulation is providad by two inches of polystyrene foam on the bottom, and four inches on the top and sides. The tank is five feet by six feet by four feet high.

Space Heating - The space heating subsystem consists of an electric dual source (water or air) to air heat pump and electric resistance heaters, and a solar heating coil in the duct. Solar energy from storage is used either directly in the heating coil, or as a source for the heat pump evaporator. The heat pump is a model 22-21, Climate Master, capacity 21,500 BTU, manufactured by Friedrich. 
Hot Water - Energy from storage is used to heat domestic hot water in a 120gallon Sepco Solar Energy Water Heater manufactured by the Vaughn Corp. When solar energy is insufficient to satisfy the DHW load, a 4,200 watt electrical immersion heater in the top of the DHW tank provides auxiliary energy for heating the supply water. Solar energy is transferred from the storage to the DHW tank by a heat exchanger in the storage tank, and another heat exchanger in the bottom of the DHW tank. Water is used as the transfer medium. 


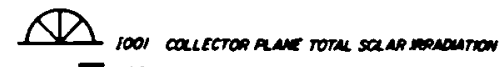

$\nabla$ roo artooco newerenture

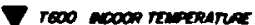

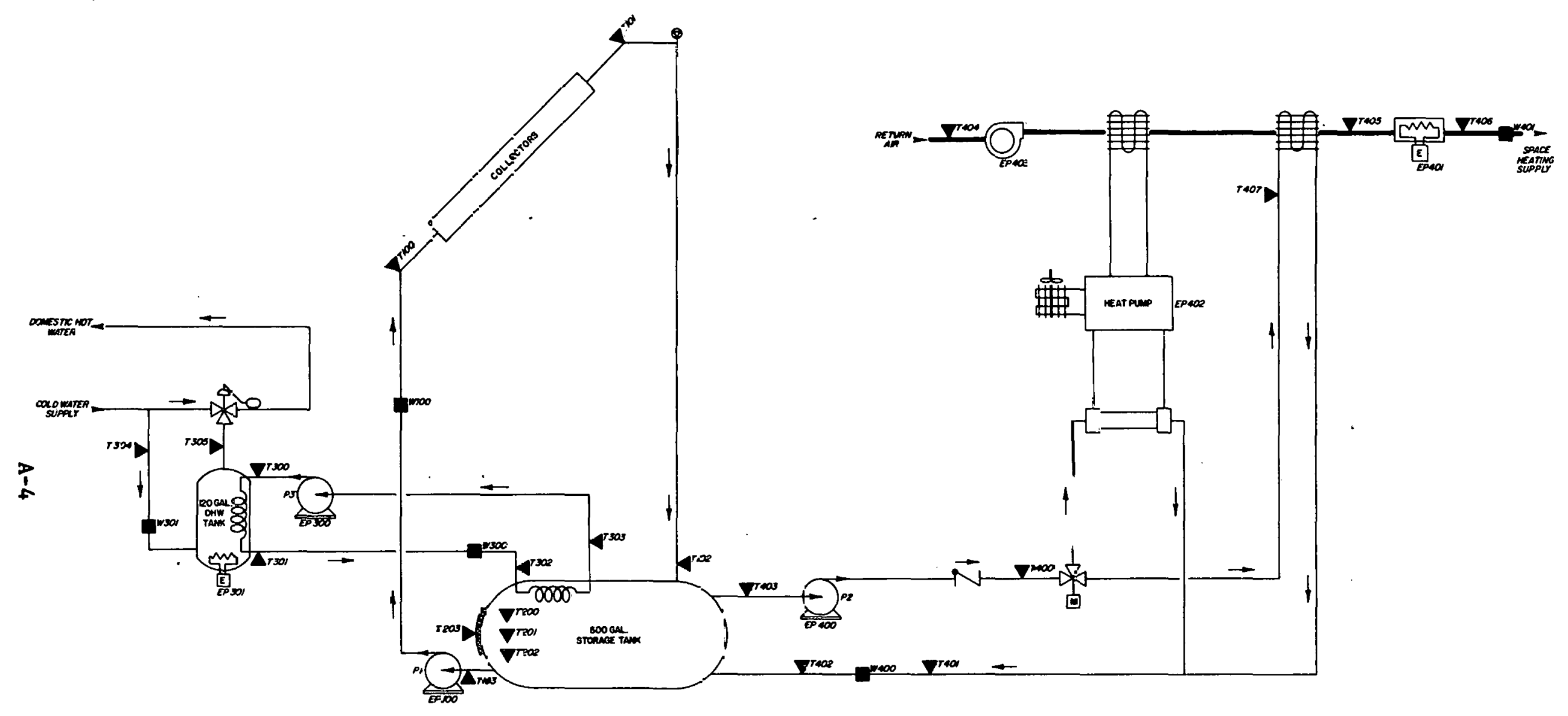

Figure A-i. Summerwood Associates, House M Solar Energy System Schematic 


\section{APPENDIX B}

\section{PERFORMANCE EVALUATION TECHNIQUES}

The performance of the Summerwood Associates, House M solar energy system is evaluated by calculating a set of primary performance factors which are based on those in the intergovernmental agency report "Thermal Data Requirements and Performance Evaluation Procedures for the National Solar Heating and Cooling Demonstration Program" (NBSIR-76/1137).

An overview of the NSDN data collection and dissemination process is shown in Figure $B-1$.

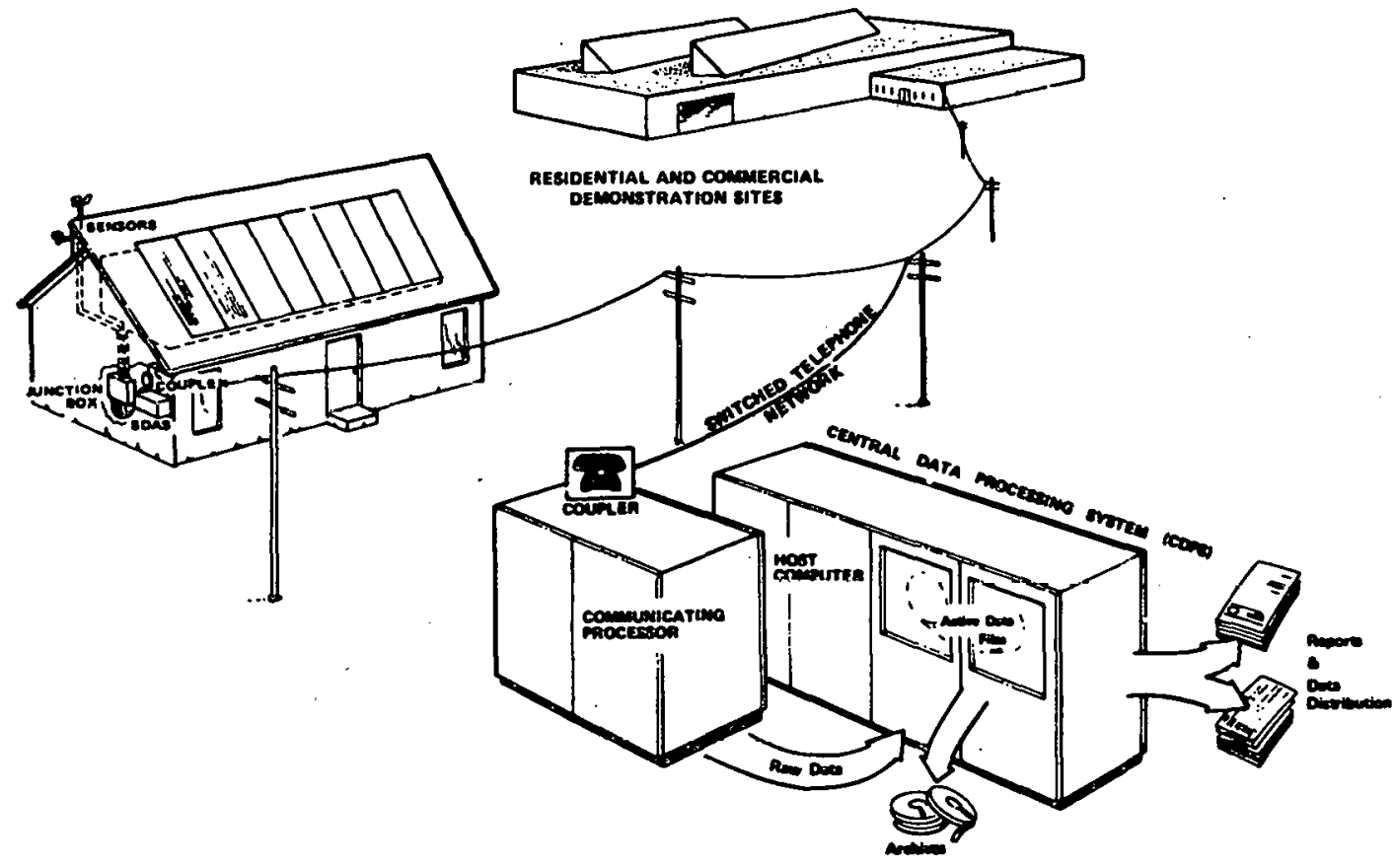

Figure B-1. The National Solar Data Network 
Each site contains standard industrial instrumentation modified for the particular site. Sensors measure temperatures, flows, insolation, electric power, fossil fuel usage, and other parameters. These sensors are all wired into a junction box ( $J$-box), which is in turn connected to a microprocessor data logger called the Site Data Acquisition Subsystem (SDAS). The SDAS can read up to 96 different channels, one channel for each sensor. The SDAS takes the analog voltage input to each channel and converts it to a 10-bit word. At intervals of every 320 seconds, the SDAS samples each channel and records the values on a cassette tape. Some of the channels can be sampled 10 times in each 320 second interval, and the average value is recorded in the tape.

Each SDAS is connected through a modem to voice-grade telephone lines which are used to transmit the data to a central computer facility. This facility is the Central Data Processing System (CDPS), located at Vitro Laboratories in Silver Spring, Maryland. The CDPS hardware consists of an IBM System 7, an IBM $370 / 145$, and an IBM 3033. The System 7 periodically calls up each SDAS in the system and has the SDAS tranemit the data on the casselle lape back to the System 7. Typically, the System 7 collects data from each SDAS six times a week, although the tape can hold three to five days of data, depending on the number of channels.

The data received by the System 7 are in the form of digital counts in the range of $0-1,023$.. These counts are then processed by software in the CDPS, where they are converted from counts to engineering units (EU) by applying appropriate calibration constants. The engineering unit data called "detailed measurements" in the software are then tabulated on a daily basis for the site analyst. The CDPS is also capable of transforming this data into plots, graphs, and processed reports.

Bular system performance reports present system parameters as monthly values. if some of the data during the month is not collected due to solar system, instrumentation system, or data acquisition problems, or if some of the collected data is invalid, then the collectcd valid data is exlrapolated to provide the monthly performance ertimntes. Researchele uul ulher useis who require unextrapolated, "raw" data may obtain data by contacting Vitro Laboratories.

\section{DATA ANALYSIS}

The analyst develops a unique set of "site equations" (given in Appendix D) for each site in the NSDN, following the guidelines presented herein.

The equations calculate the flow of energy through the system, including solar energy, auxiliary energy, and losses. These cquations are progranued in PL/1 and become part of the Central Data Processing System. The PL/1 program for each site is termed the site software. The site software processes the detailed data, using as input a "measurement record" containing the data for each scan interval. The site software produces as output a set of performance factors, on an hourly, daily, and monthly basis. 
These performance factors (Appendix C) quantify the thermal performance of the system by computing energy flows throughout the various subsystems. The system performance may then be evaluated based on the efficiency of the system in transferring these energies.

Performance factors which are considered to be of primary importance are those which are essential for system evaluation. Without these primary performance factors: (which are denoted by an asterisk in Appendix C), comparative evaluation of the wide variety of solar energy systems would be impossible. An example of a primary performance factor is SECA - Solar Energy Collected by the Array. This is quite obviously a key parameter in system analysis.

Secondary performance factors are data deemed important and useful in comparison and evaluation of solar systems, particularly with respect to component interactions and simulation. In most cases these. secondary performance factors are computed as functions of primary performance factors.

There are irregularly occurring cases of missing data as is normal for any realtime data collection from mechanical equipment. When data for individual scans or whole hours are missing, values of performance factors are assigned which are interpolated from measured data. If no valid measured data are available for interpolation, a zero value is assigned. If data are missing for a whole day, each hour is interpolated separately. Data are interpolated in order to provide solar system performance factors on a whole hour; whole day and whole month basis for use by architects and designers.

\section{REPORTING}

The performance of the Summerwood Associates, House M solar energy system from June 1980 through May 1981 was analyzed and Monthly Performance Report's were published through December 1980. See the following page for a list of these reports.

In addition, data are included in this report which are not in Monthly Performance Reports. 
OTHER DATA REPORTS ON THIS STTE*

Monthly Performance Reports:

April 1980, SOLAR/1102-80/04

May 1980 , SOLAR/1102-80/05

June 1980, SOLAR/1102-80/06

July 1980 , SOLAR/1102-80/07

November 1980 , SOLAR/1102-80/11

December 1980, SOLAR/1102-80/12

* These reports can be obtained (free) by contacting: U.S. Department of Energy, Technical Information Center, P.0. Box 62, Oak Ridge, TN 37830. 


\section{APPENDIX C}

\section{PERFORMANCE FACTORS AND SOLAR TERMS}

The performance factors identified in the site equations (Appendix D) by the use of acronyms or symbols are defined in this Appendix in Section 1 . Section 1 includes the acronym, the actual name of the performance factor, and a short definition.

Section 2 contains a glossary of solar terminology, in alphabetical order. These terms are included for quick reference by the reader.

Section 3 describes general acronyms used in this report.

Section 1. Performance Factor Definitions and Acronyms

Section 2. Solar Terminology

Section 3. General Acronyms 


\section{SECTION 1. PERFORMANCE FACTOR DEFINITIONS AND ACRONYMS}

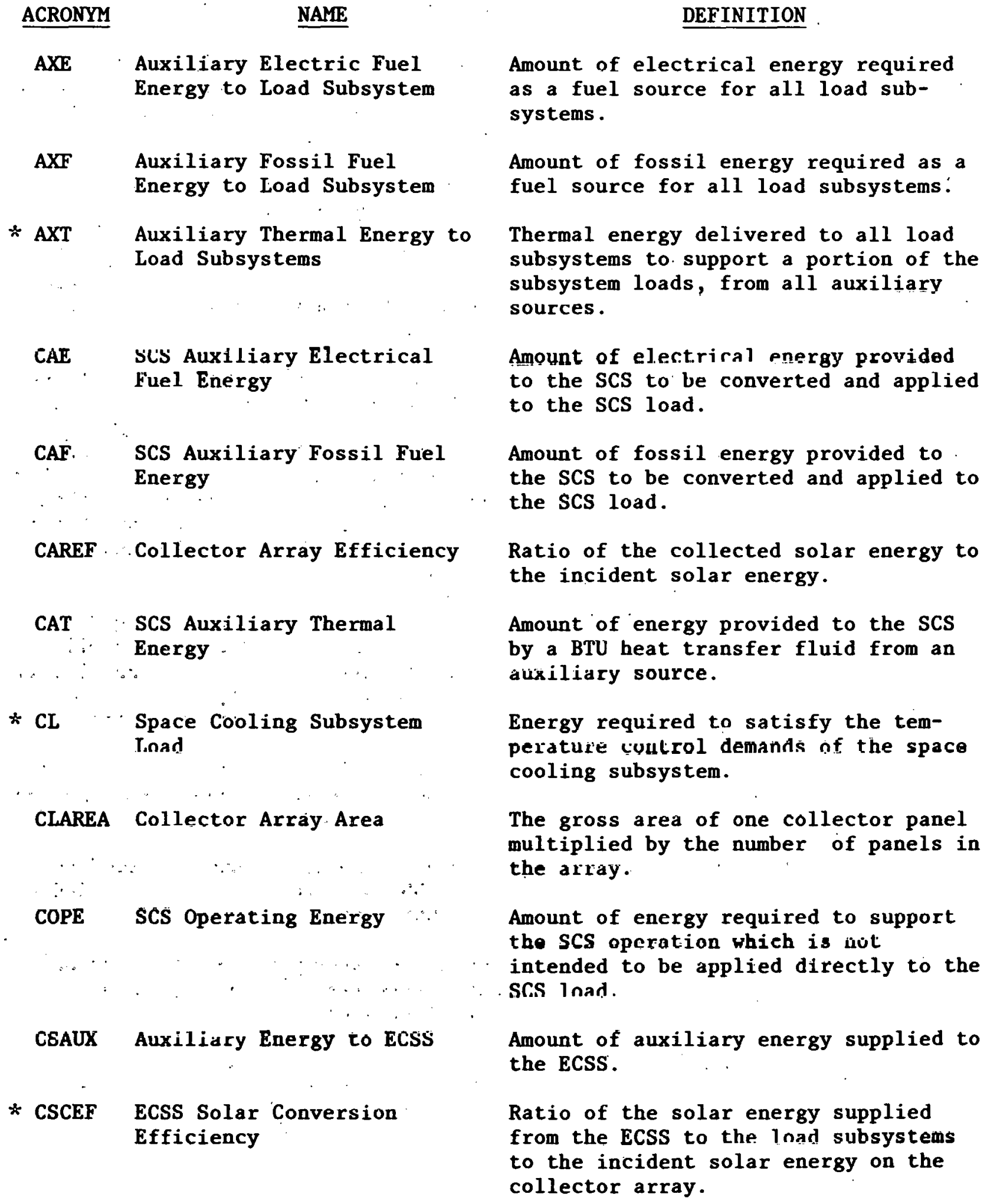

The gross area of one collector panel multiplied by the number of panels in the array.

Amount of energy required to support tho SCS operation which is nut intended to be applied directly to the SCS Inad.

Amount of auxiliary energy supplied to the ECSS.

Ratio of the solar energy supplied from the ECSS to the load subsystems to the incident solar energy on the collector array.

* Primary Performance Factors 


\begin{tabular}{|c|c|c|}
\hline ACRONYM & NAME & DEFINITION \\
\hline CSE & Solar Energy to SCS & $\begin{array}{l}\text { Amount of solar energy delivered to } \\
\text { the SCS. }\end{array}$ \\
\hline CSEO & $\begin{array}{l}\text { Energy Delivered from ECSS } \\
\text { to Load Subsystems }\end{array}$ & $\begin{array}{l}\text { Amount of energy supplied from the } \\
\text { ECSS to the load subsystems (including } \\
\text { any auxiliary energy supplied to the } \\
\text { ECSS). }\end{array}$ \\
\hline * CSFR & SCS Solar Fraction & $\begin{array}{l}\text { Portion of the SCS load which is sup- } \\
\text { ported by solar energy. }\end{array}$ \\
\hline CSOPE & ECSS Operating Energy & $\begin{array}{l}\text { Amount of energy used to support the } \\
\text { ECSS operation (which is not intended } \\
\text { to be supplied to the ECSS thermal } \\
\text { state). }\end{array}$ \\
\hline CSRJE & ECSS Rejected Energy & $\begin{array}{l}\text { Amount of energy intentionally reject- } \\
\text { ed or dumped from the ECSS subsystem. }\end{array}$ \\
\hline$*$ CSVE & $\begin{array}{l}\text { SCS Electrical Energy } \\
\text { Savings }\end{array}$ & $\begin{array}{l}\because \text { Difference in the electrical energy } \\
\text { required to support an assumed similar } \\
\text { conventional SCS and the actual elec- } \\
\text { trical energy required to support the } \\
\text { demonstration SCS, for identical SCS } \\
\because \text { loads. }\end{array}$ \\
\hline$\star C S V F$ & SCS Fossil Energy Savings & $\begin{array}{l}\text { Difference in the fossil energy re- } \\
\text { quired to support an assumed similar } \\
\text { conventional SCS and the actual fossil } \\
\text { energy required to support the demon- } \\
\text { stration SCS, for identical loads. }\end{array}$ \\
\hline HAE & $\begin{array}{l}\text { SHS Auxiliary Electrical } \\
\text { Fuel Energy }\end{array}$ & $\begin{array}{l}\therefore \quad \text { Amount of electrical energy provided } \\
\text { to the SHS to be converted and applied } \\
\text { to the SHS load. }\end{array}$ \\
\hline HAF & $\begin{array}{l}\text { SHS Auxiliary Fossil Fuel } \\
\text { Energy }\end{array}$ & $\begin{array}{l}\text { Amount of fossil energy provided to } \\
\text { the SHS to be converted and applied to } \\
\text { the SHS load. }\end{array}$ \\
\hline HAT & $\begin{array}{l}\text { SHS Auxiliary Thermal } \\
\text { Energy }\end{array}$ & $\begin{array}{l}\text { Amount of energy provided to the SHS } \\
\text { by a heat transfer fluid from an } \\
\text { auxiliary source. }\end{array}$ \\
\hline * HIL & $\begin{array}{l}\text { Space Heating Subsystem } \\
\text { Load }\end{array}$ & $\begin{array}{l}\text { Energy required to satisfy the tem- } \\
\text { perature control demands of the space } \\
\text { heating subsystem. }\end{array}$ \\
\hline
\end{tabular}

* Primary Performance Factors 


\begin{tabular}{|c|c|c|c|}
\hline & ACRONYM & NAME & DEFINITION \\
\hline & HOPE & SHS Operating Energy & $\begin{array}{l}\text { Amount of energy required to support } \\
\text { the SHS operation (which is not } \\
\text { intended to be applicd dircetly to the } \\
\text { SHS load). }\end{array}$ \\
\hline & HOURCT & Record Time & $\begin{array}{l}\text { Count of hours elapsed from the start } \\
\text { of } 1977 \text {. }\end{array}$ \\
\hline$\star$ & HSFR & SHS Solar Fraction & $\begin{array}{l}\text { Portion of the SHS load which is sup- } \\
\text { ported by solar energy. }\end{array}$ \\
\hline & HSE & Solar Energy to SHS & $\begin{array}{l}\text { Amount of solar energy delivered to } \\
\text { the SHS. }\end{array}$ \\
\hline * & HSVE & $\begin{array}{l}\text { SHS Electrical Energy } \\
\text { Savings }\end{array}$ & $\begin{array}{l}\text { Difference in the electrical energy } \\
\text { required to support an assumed similar } \\
\text { conventional SHS and the actual elec- } \\
\text { trical energy required to support the } \\
\text { demonstration SHS, for identical SHS } \\
\text { loads. }\end{array}$ \\
\hline * & HSVF & SHS Fossil Energy Savings & $\begin{array}{l}\text { Difference in the fossil energy re- } \\
\text { quired to support an assumed similar } \\
\text { conventional SHS and the actual fossil } \\
\text { energy required to support the demon- } \\
\text { stration SHS, for identical SHS loads. }\end{array}$ \\
\hline & HWAE & $\begin{array}{l}\text { HWS Auxiliary Electrical } \\
\text { Fuel Energy }\end{array}$ & $\begin{array}{l}\text { Amount of electrical energy provided } \\
\text { to the HWS to be converted and applied } \\
\text { to the HWS load. }\end{array}$ \\
\hline & HWAF & $\begin{array}{l}\text { HWS Auxiliary Fossil Fuel } \\
\text { Energy }\end{array}$ & $\begin{array}{l}\text { Amount of fossil energy provided to } \\
\text { the HWS to be converted and applied to } \\
\text { the HWS load. }\end{array}$ \\
\hline & HWAT & $\begin{array}{l}\text { HWS Auxiliary Thermal } \\
\text { Energy }\end{array}$ & $\begin{array}{l}\text { Amount of energy provided to the HWS } \\
\text { by a heat transfer fluid from an } \\
\text { auxiliary source. }\end{array}$ \\
\hline & HWCSM & $\begin{array}{l}\text { Service Hot Water } \\
\text { Consumption }\end{array}$ & $\begin{array}{l}\text { Amount of heated water delivered to } \\
\text { the load from the hot water subsystem. }\end{array}$ \\
\hline & HWL & Hot Water Subsystem Load & $\begin{array}{l}\text { Energy required to satisfy the tem- } \\
\text { perature control demands of the build- } \\
\text { ing service hot water system. }\end{array}$ \\
\hline
\end{tabular}

F Primary Performance Factors 
ACRONYM

NAME

HWOPE HWS Operating Energy.

HWSE Solar Energy to HWS

* HWSFR HWS Solar Fraction

* HWSVE HWS Electrical Energy Savings

* HWSVF HWS Fossil Energy Savings

RELH Relative Humidity

* SE Incident Solar Energy

SECA Collected Solar Energy by

SEDF Diffuse Insolation

SEOP Array

Incident Solar Energy on Array

Collector. Solar Energy

Operational Incident Solar Energy
DEFINITION

Amount of energy required to support the HWS operation which is not intended to be applied directly to the HWS load.

Amount of solar energy delivered to the HWS.

Portion of the HWS load which is supported by solar energy.

Difference in the electrical energy required to support an assumed similar conventional HWS and the actual electrical energy required to support the demonstration HWS, for identical HWS loads.

Difference in the fossil energy required to support an assumed similar conventional HWS and the actual fossil energy required to support the demonstration HWS, for identical loads.

Average outdoor relative humidity at the site.

Amount of solar energy incident upon one square foot of the collector plane.

Amount of solar energy incident upon the collector array.

Amount of thermal energy added to the heat transfer fluid for each square foot of the colleclur area.

Amount of thermal energy added to the heat transfer fluid by the collector array.

Amount of diffuse solar energy incident upon one square foot of a collector plane.

Amount of incident solar energy upon the collector array whenever the collector loop is active.

* Primary Performance Factors 


\begin{tabular}{|c|c|c|}
\hline \multicolumn{2}{|c|}{ ACRONYM } & NAME \\
\hline * & SEL & $\begin{array}{l}\text { Solar Energy to Load } \\
\text { Subsystems }\end{array}$ \\
\hline$\star$ & SFR & $\begin{array}{l}\text { Solar Fraction of System } \\
\text { Load }\end{array}$ \\
\hline & STECH & $\begin{array}{l}\text { Change in ECSS Stored } \\
\text { Energy }\end{array}$ \\
\hline & STEFF & ECSS Storage Efficiency \\
\hline & STEI & $\begin{array}{l}\text { Energy Delivered to ECSS } \\
\text { Stnrage }\end{array}$ \\
\hline & STEO & $\begin{array}{l}\text { Energy Supplied by ECSS } \\
\text { Storage }\end{array}$ \\
\hline$\star$ & SYSL & System Load \\
\hline$\star$ & SYSOPE & System Operating Energy \\
\hline$\star$ & SYSPF & System Performance Factor \\
\hline * & TA & Ambient Temperature \\
\hline$\star$ & TB & Building Temperature \\
\hline & TCECOP & $\begin{array}{l}\text { TCE Coefficient of } \\
\text { Performance }\end{array}$ \\
\hline & TCEI & TCE Thermal Input Energy \\
\hline
\end{tabular}

DEFINITION

Amount of solar energy supplied by the ECSS to all load subsystems.

Portion of the system load which was supported by solar energy.

Change in ECSS stored energy during reference time period.

Ratio of the sum of energy supplied by ECSS storage and the change in ECSS stored energy to the energy delivered to the F.C.ss storage.

Amount of energy delivered to ECES storage by the culleclur array and from auxiliary sources.

Amount of energy supplied by ECSS storage to the load subsystems.

Energy required to satisfy all desired temperature control demands at the output of all subsystems.

Amount of energy required to support the system operation, including all subsystems, which is not intended to be applied directly to the system load.

Ratio of the system load to the total equivalent fossil energy expended or required to support the system load.

Average temperature of the ambient air.

Average temperature of the controlled space ot the building.

Coefficient of performance of the thermodynamic conversion equipweul.

Equivalent thermal energy which is supplied as a fuel source to thermodynamic conversion equipment.

* Primary Performance Factors 
ACRONYM

NAME

TCEL Thermodynamic Conversion Equipment Load

TCEOPE TCE Operating Energy

TCERJE TCE Reject Energy

TDA Daytime Average Ambient Temperature

* TECSM Total Energy Consumed by System

THW Service Hot Water Temperature

TST ECSS Storage Temperature

* TSVE

Total Electrical Energy Savings

$\star$ TSVF

Total Fossil Energy Savings

TSW
Supply Water Temperature
DEFINITION

Controlled energy output of thermodynamic conversion equipment.

Amount of energy required to support the operation of thermodynamic conversion equipment which is not intended to appear directly in the load.

Amount of energy intentionally rejected or dumped from thermodynamic conversion equipment as a by-product or consequence of its principal operation.

Average temperature of the ambient air during the daytime (during normal collector operation period).

Amount of energy demand of the system from external sources; sum of all fuels, operating energies, and collected solar energy.

Average temperature of the service hot water supplied by the system.

Average temperature of the ECSS storage medium.

Difference in the estimated electrical energy required to support an assumed similar conventional system and the actual electrical energy required to support the system, for identical loads; sum of electrical energy savings for all subsystems.

Difference in the estimated fossil energy required to support an assumed similar conventional system and the actual fossil energy required to support the system, for identical loads; sum of fossil energy savings of all subsysteims.

Average temperature of the supply water to the hot water subsystem.

* Primary Performance Factors 
ACRONYM

NAME

WDIR Wind Direction

WIND Wind Velocity
DEFINITION

Average wind direction at the site.

Average wind velocity at the site. 
Absorptivity

Active Solar System

\section{Air Conditioning}

Ambient Temperature

Auxiliary Energy

Auxiliary Energy Subsystem

Array

Backflow

Backflow Preventer

Beam Radiation

Collected Solar Energy
The ratio of absorbed radiation by a surface to the total incident radiated energy on that surface.

A system in which a transfer fluid (liquid or air) is circulated through a solar collector where the collected energy is converted, or transferred, to energy in the medium.

Popularly defined as space cooling, more precisely, the process of treating indoor air by controlling the temperature, humidity and distribution to maintain specified comfort conditions.

The surrounding air temperature.

In solar energy technology, the energy supplied to the heat or cooling load from other than the solar source, usually from a conventional heating or cooling system. Excluded are operating energy, and energy which may be supplemented in nature but does not have the auxiliary system as an origin, i.e., energy supplied to the space heating load from the external ambient environment by a heat pump. The electric energy input to a heat pump is defined as operating energy.

In solar energy technology the Auxiliary Energy System is the conventional heating and/or cooling equipment used as supplemental or backup to the solar system.

An assembly of a number of collector elements, or pariels, into the solar collector for a solar energy system.

Reverse flow.

A valve or damper installed to prevent reverse flow.

Radiated energy received directly, not from scattering or reflecting sources.

The thermal energy added to the heat transfer fluid by the solar collector. 
Collector Array Efficiency

Collector Subsystem

Concentrating Solar Collector

Conversion Efficiency

Conditioned Space

Control System or Subsystem

Cooling Degree Days

Cooling Tower

Diffuse Radiation

Drain Down

Duct Heating Coil

Effective Heat Transfer Coefficient

Energy Gain
Same as Collector Conversion Efficiency. Ratio of the collected solar energy to the incident solar energy. (See also Operational Collector Efficiency.)

The assembly of components that absorbs incident solar energy and transfers the absorbed thermal energy to a heat transfer fluid.

A solar collector that concentrates the energy from a larger area onto an absorbing element of smaller area.

Ratio of thermal energy output to solar energy incident on the collector array.

The space in a butluing in which the air is heated or cooled to maintain a desired temperature range.

The assembly of electric, pneumatic, or hydraulic, sensing, and actuating devices used to control the operating equipment in a system.

The sum over a specified period of time of the number of degrees the average daily temperature is above $65^{\circ} \mathrm{F}$.

A heat exchanger that transfers waste heat to outside ambient air.

Solar Radiation which is scattered by air molecules, dust, or water droplets and incapable of being focused.

An arrangement of sensors, valves and actuators to automatically drain the solar collectors and collector piping to prevent freezing in the event of cold weather.

A liquid-to-air heat exchanger in the duct distribution system.

The heat transfer coefficient, per unit plate area of a collector, which is a measure of the total heat losses per unit area from all sides, top, back, and edges.

The thermal energy gained by the collector transfer fluid. The thermal energy output of the collector. 
Energy · Savings

Expansion Tank

F-Curve

Fixed Collector

Flat Plate Collector

Focusing Collector

Fossil Fuel

Glazing
The estimated difference between the fossil and/or electrical energy requirements of an assumed conventional system (carrying the full measured load) and the actual electrical and/or fossil energy requirements of the installed solar-assisted system.

A tank with a confined volume of air (or gas) whose inlet port is open to the system heat transfer fluid. The pressure and volume of the confined air varies as to the system heat transfer fluid expands and contracts to prevent excessive pressure from developing and causing damage.

The collector instantaneous efficiency curve. Used in the " $\mathrm{F}$-curve" procedure for collector analysis (see Instantaneous Efficiency).

A solar collector that is fixed in position and cannot be rotated to follow the sun daily or seasonably.

A solar energy collecting device consisting of a relatively thin panel of absorbing material. A container with insulated bottom and sides and covered with one or more covers transparent to visible solar energy and relatively opaque to infrared energy.- Visible energy from the sun enters through the transparent cover and raises the temperature of the absorbing panel. The infrared energy re-radiated from. the panel. is trapped within the collector because it cannot pass through the cover. Glass is an effective cover material (see Selective Surface).

A concentrating type collector using parabolic mirrors or optical lenses to focus the energy from a large area onto a small absorbing area.

Petroleum, coal, and natural gas derived fuels.

In solar/energy technology, the transparent covers used to reduce energy losses from a collector panel. 
Heat Exchanger

Heat Transfer Fluid

Heating Degree Days

Instantaneous Efficiency

Instantaneous Efficiency Curve

Incidence Angle

Incident Solar Energy

Insolation

Luad

Manifold

Microclimate
A device used to transfer energy from one heat transfer fluid to another while maintaining physical segregation of the fluids. Normally used in systems to provide an interface between two different heat transfer fluids.

The fluid circulated through a heat source (solar collector) or heat exchanger that transports the thermal energy by virtue of its temperature.

The sum over a specified period of time of the number of degrees the average daily temperature is heluw $6.5^{\circ} \mathrm{F}$.

The efficiency of a solar collector at one operating point, $\frac{\mathrm{Ti}-\mathrm{Ta}}{\mathrm{I}}$, under steady state conditions (see Operating Point).

A plot of solar collector efficiency against operating point, $\frac{T i-T a}{I}$ (see operating Point).

The angle between the line to a radiating source (the sun) and a line normal to the plane of the surface being irradiated.

The amount of solar cnergy irradiating a surface taking into account the angle of incidence. lhe effective area receiving energy is the product of the area of the surface times the cosine of the angle of incidence.

Incoming snlar radiation.

That to which energy is supplied, such as space heating load or cooling load. The system load is the total solar and auxiliary energy required to satisfy the required heating or cooling.

The piping that distributes the transport fluid to and from the individual panels of a collector array.

Highly localized weather features which may differ from long term regional values due to the interaction of the local surface with the atmosphere. 
Nocturnal Radiation

Operating Energy

Operating Point

Operational Collector Efficiency

Outgassing

Passive Solar System

Pebble Bed (Rock Bed)

Reflected Radiation

Rejected Energy

Retrofit

Selective Surface
The loss of thermal energy by the solar collector to the night sky.

The amount of energy (usually electrical energy) required to operate the solar and auxiliary equipments and to transport the thermal energy to the point of use, and which is not intended to directly affect the thermal state of the system.

A solar energy system has a dynamic operating range due to changes in level of insolation (I), fluid input temperature (T), and outside ambient temperature (Ta). The operating point is defined as:

$\frac{\text { Ti-Ta }}{\text { I }} \frac{\text { of } \times \text { hr. } x \text { sq. ft. }}{\text { BTU }}$

Ratio of collected solar energy to incident solar energy only during the time the collector fluid is being circulated with the intention of delivering solar-source energy to the system.

The emission of gas by materials and components, usually during exposure to elevated temperature, or reduced pressure.

A system which uses architectural components of the building to collect, distribute, and store solar energy.

A space filled with uniform-sized pebbles to store solar-source energy by raising the temperature of the pebbles.

Insolation reflected from a surface, such as the ground or a reflecting element onto the solar collector.

Energy intentionally rejected, dissipated, or dumped from the solar system.

The addition of a solar energy system to an existing structure.

A surface that has the ability to readily absorb solar radiation, but re-radiates little of it as thermal radiation. 
Sensor

Solar Conditioned Space $\because$

Solar Fraction

Solar Savings Ratio

Storage Efticiency, $\mathrm{N}_{\mathrm{S}}$

Storage Subsystem

Stratification

System Performance Factor

I

Ton of Refrigeration

Tracking Collector

Zone
A device used to monitor a physical param eter in a system, such as temperature or flow rate, for the purpose of measurement or control.

The area in a building that depends on solar energy to provide a fraction of the heating and cooling needs.

The fraction of the total load supplied by solar energy. The ratio of solar energy supplied to loads divided by total load. often expressed as a percentage.

The ratio of the solar energy supplied to the load minus the solar system operating energy, divided by the system load.

Measure of effectiveness of transfer of energy through the storage subsystem taking into account system losses.

The assembly of components used to store solar-source energy for use during periods of low insolation.

A phenomenon that causes a distinct thermal gradient in a heat transfer fluid, in contrast to a thermally homogeneous fluid. Results in the layering of the heat transfer fluid, with each layer at a different. temperature. In solar energy systems, stratification can occur in liquid storage tanks or rock beds, and may even occur in pipes and ducts. The temperature gradient or layering may occur in a horizontal, vertical or radial direction.

Ratio of system load to the total equivalent fossil energy expended or required to support the system load.

The heat equivalent to the melting of one ton $\left(2,000\right.$ pounds) of ice at $32^{\circ} \mathrm{F}$ in 24 hours. A ton of refrigeration will absorb $12,000 \mathrm{BTU} / \mathrm{hr}$, or $288,000 \mathrm{DTU} / \mathrm{day}$.

A solar collector that moves to point in the direction of the sun.

A portion of a conditioned space that is controlled to meet heating or cooling requirements separately from the other space or other zones. 


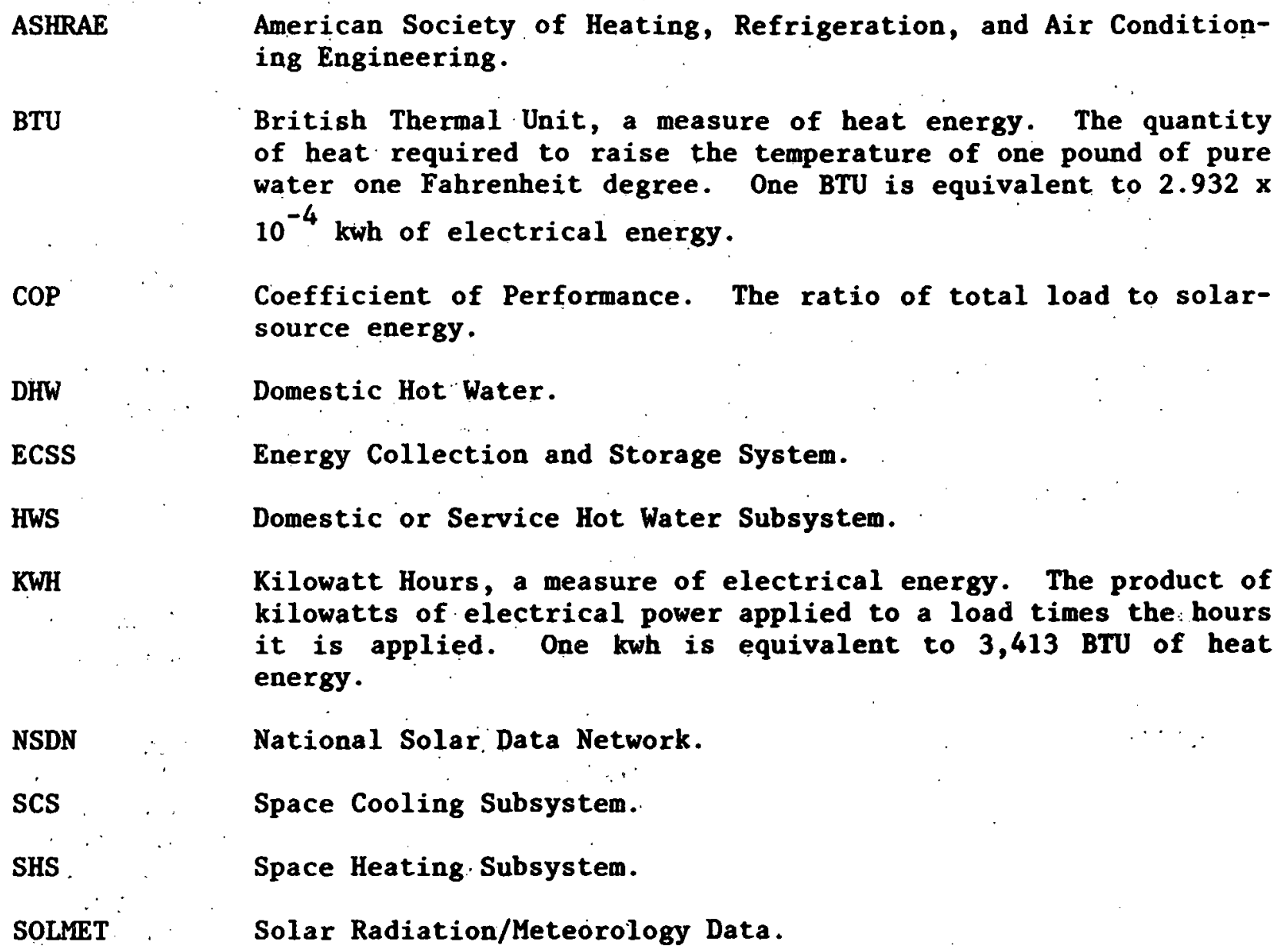




\author{
APPENDIX D \\ PERFORMANCE EQUATIONS \\ SUMERWOOD ASSOCIATES, HOUSE M
}

\title{
INTRODUCTION
}

Solar energy system performance is evaluated by performing energy balance computations on the system and its major subsystems. These calculations are based on physical measurement data taken from each sensor every 320 seconds.* This data is then mathematically combined to determine the hourly, daily, and monthly performance of the system. This appendix describes the general computational methods and the specific energy balance equations used for this site.

Data samples from the system measurements are integrated to provide discrete approximations of the continuous functions which characterize the system's dynamic behavior. This integration is performed by summation of the product of the measured rate of the appropriate performance parameters and the sampling interval over the total time period of interest.

There are several general forms of integration equations which are applied to each site. These general forms are exemplified as follows: the total solar energy available to the collector array is given by

$$
\text { SOLAR ENERGY AVAILABLE }=(1 / 60) \Sigma[1001 \times \text { AREA }] \times \Delta \tau
$$

where 1001 is the solar radiation measurement provided by the pyranometer in BTU per square foot per hour, AREA is the area of the collector array in square feet, $\Delta \tau$ is the sampling interval in minutes, and the factor $(1 / 60)$ is included to correct the solar radiation "rate" to the proper units of time.

Similarly, the energy flow within a system is given typically by

$$
\text { COLLECTED SOLAR ENERGY }=\Sigma[M 100 \times \Delta H] \times \Delta \tau
$$

where $\mathrm{M} 100$ is the mass flow rate of the heat transfer fluid in $1 \mathrm{~b}_{\mathrm{m}} / \mathrm{min}$ and $\Delta H$ is the enthalpy change, in BTU/lb $m$, of the fluid as it passes through the heat exchanging component.

For a liquid system $\Delta H$ is generally given by

$$
\Delta H=\bar{C}_{p} \Delta T
$$

where $C_{p}$ is the average specific heat, in $B T U / 1 b_{m}{ }^{\circ} F$, of the heat transfer fluid and $\Delta \mathrm{T}$, in ${ }^{\circ} \mathrm{F}$, is the temperature differential across the heat exchanging component.

* See Appendix B. 
For an air system $\Delta H$ is generally given by

$$
\Delta H=H_{a}\left(T_{\text {out }}\right)-H_{a}\left(T_{\text {in }}\right)
$$

where $H_{a}(T)$ is the enthalpy, in $B T U / 1 b_{m}$, of the transport air evaluated at the inlet and outlet temperatures of the heat exchanging component.

$H_{a}(T)$ can have various forms, depending on whether or not the humidity ratio of the transport air remains constant as it passes through the heat exchanging component.

For electrical power, a general example is

$$
\text { ECSS OPERATING ENERGY }=(3413 / 60) \Sigma[\text { EP100] } \times \Delta \tau \text {. }
$$

where EP100 is the power required by electrical equipment in kilowatts and the two factors $(1 / 60)$ and 3413 correct the data to BTU/min.

\begin{tabular}{|c|c|c|}
\hline$C$ or $C P$ & $\doteq$ & Specific Heat \\
\hline D & $=$ & Direction or Position \\
\hline EE & $=$ & Electric Energy \\
\hline EP & $=$ & Electric Power \\
\hline $\mathbf{F}$ & $=$ & Fuel Flow Rate \\
\hline HWD & $=$ & $\begin{array}{l}\text { Functional procedure to calculate the specific heat of } \\
\text { water at the average of the inlet and outlet } \\
\text { temperatures }\end{array}$ \\
\hline $\mathbf{H}$ & $=$ & Enthalpy \\
\hline HR & $=$ & Humidity Ratio \\
\hline I & $=$ & Incident Solar Flux (Insolation) \\
\hline M & $=$ & Mass Flow Rate \\
\hline $\mathbf{N}$ & $=$ & Performance Parameter. \\
\hline $\mathbf{P}$ & $=$ & Preesure \\
\hline PD & $=$ & Differential Pressure \\
\hline Q & $=$ & Thermal Energy \\
\hline RHO & $=$ & Density \\
\hline $\mathrm{T}$ & $=$ & Temperature \\
\hline TD & $=$ & Differential Temperature \\
\hline $\mathbf{v}$ & $=$ & Velocity \\
\hline W & $=$ & Heat Transport Medium Volume Flow Rate \\
\hline TI & $=$ & Time \\
\hline $\mathbf{P}$ & $=$ & $\begin{array}{l}\text { Appended to a function designator to signify the value of } \\
\text { the function during the previous iteration }\end{array}$ \\
\hline
\end{tabular}

\section{Letter Designations}


Subsystem Designations

Number Sequence

001 to 099
100 to 199
200 to 299
300 to 399
400 to 499
500 to 599
600 to 699

Subsystem/Data Group

Climatological

Collector and Heat Transport

Thermal Storage

Hot Water

Space. Heating

Space Cooling

Building/Load

EQUATIONS USED TO GENERATE MONTHLY PERFORMANCE VALUES

AVERAGE AMBIENT TEMPERATURE $\left({ }^{\circ}\right.$ F $)$

$\mathrm{TA}=(1 / 60) \times \Sigma \mathrm{T} 001 \times \Delta \tau$

AVERAGE BUILDING TEMPERATURE ( $\left.{ }^{\circ} \mathrm{F}\right)$

$\mathrm{TB}=(1 / 60) \times \Sigma \mathrm{T} 600 \times \Delta \tau$

DAYTIME AVERAGE AMBIENT TEMPERATURE $\left({ }^{\circ} \mathrm{F}\right)$

$$
\begin{aligned}
\text { TDA }= & (1 / 360) \times \Sigma T 001 \times \Delta \tau \\
& \text { for } \pm \text { three hours from solar noon }
\end{aligned}
$$

INCIDENT SOLAR ENERGY PER SQUARE FOOT (BTU/FT ${ }^{2}$ )

$$
\mathrm{SE}=(1 / 60) \times \Sigma 1001 \times \Delta \tau
$$

OPERATIONAL INCIDENT SOLAR ENERGY (BTU)

$$
\text { SEOP }=(1 / 60) \times \Sigma[1001 \times \text { CLAREA }] \times \Delta \tau
$$

when the collector loop is active

SPECIFIC HEAT FUNCTION FOR WATER

$$
\begin{aligned}
\mathrm{H}(\mathrm{TH}, \mathrm{TL})= & 1.01146 \times(\mathrm{TH}-\mathrm{TL})-1.17403 \times 10^{-4} \times\left(\mathrm{TH}^{2}-\mathrm{TL}^{2}\right)+3.457 \\
& \times 10^{-7} \times\left(\mathrm{TH}^{3}-\mathrm{TL}^{3}\right)
\end{aligned}
$$

SOLAR ENERGY COLLECTED BY THE ARRAY (BTU)

$$
\text { SECA }=\Sigma[M 100 \times(H(T 101, T 100))] \times \Delta \tau
$$


SOLAR ENERGY TO STORAGE (BTU)

STEI $=\Sigma[M 100 \times(H(T 102, T 103))] \times \Delta \tau$

AVERAGE TEMPERATURE OF STORAGE $\left({ }^{\circ} \mathrm{F}\right)$

$\operatorname{TST}=(1 / 60) \times \Sigma[(\mathrm{T} 200+\mathrm{T} 202) / 2] \times \Delta \tau$

SOLAR ENERGY FROM STORAGE (BTU)

STEO $=\Sigma[M 400 \times H(T 403, T 402)+M 300 \times H(T 303, T 302)] \times \Delta \tau$

ENERGY DELIVERED FROM ECSS TO LOAD SUBSYSTEMS (BTU)

CSEO $=$ STEO

ECSS OPERATING ENERGY (BTU)

CSUPE $=56.8833 \times \bar{\Sigma}$ EP100 $\times \Delta \tau$

SPACE HEATING SUBSYSTEM OPERATING ENERGY (BTU)

HOPE $=56.8833 \times \Sigma(E P 400+E P 403+F P 1) \times \Delta \tau$

when system is in the space heating mode

FP1 is the fan power drawn by the outside heat pump fan

(air-to-air mode)

SOLAR SPECIFIC SPACE HEATING OPERATING ENERGY

HOPE $1=56.8833 \Sigma \mathrm{EP} 400 \times \Delta \tau$

when system is in direct solar heating mode

OPERATING LOSSES TO HEATING LOAD

HLOPE $=0.2 \times 56.8833 \times \Sigma(E P 400+E P 403) \times \Delta \tau$

SULAK ENERGY TO SPACE HEATING SYSTEM (BTU)

HSE $=$ HSEM + HSEL

SPACE HEATING SUBSYSTEM AUXILIARY ELECTRIC FUEL ENERGY (RTII)

HAE + HAE $1+$ HAE2

$\mathrm{HAE} 1=56.8833 \times \Sigma(E P 402-\mathrm{FP} 1) \times \Delta \tau$

HAE'2 $=56.8833 \times \Sigma E P 401$ 
SPACE HEATING SUBSYSTEM AUXILIARY THERMAL ENERGY (BTU)

$\mathrm{HAT}=\mathrm{HAE} 2+0.7 \times \mathrm{HAE} 1$

ENERGY EXTRACTED FROM OUTSIDE AIR BY HEAT PUMP

EAIR2 HLHP $-0.7 \times$ HAE1 in air-to-air mode

HEAT PUMP LOAD (BTU)

HLHP $=$ M401 $\times$ HRF $\times(T 405-T 404)$

when heat pump is supplying space heat

CONTROLLED DELIVERED ENERGY

CDE = HAT + HSEM + EAIR

SOLAR ENERGY TO CDE

HSEM $=$ M400 $\times$ H $(\mathrm{T} 400, \mathrm{~T} 401)$

direct solar mode and SAHP mode

SOLAR ENERGY LOSSES TO SHS

THLOSS = STEO (SPACE HEAT) - HSEM + 0.2 (HOPE $1+$ TCEOPE $)$

HSEL $=$ THLOSS $\times$ STEO $($ SPACE HEAT $) /($ STEO $($ SHS $)+.2($ HOPE $1+$ TCEOPE $)+$ STEO (DHW) - HWSE

SPACE HEATING SUBSYSTEM AUXILIARY THERMAL LOSSES

HATL $=0.3 \times$ HAE 1

EQUIPMENT HEATING LOAD

EHL = CDE + HTOPE + HSEL + HATL

SPACE HEATING SUBSYSTEM SOLAR FRACTION (PERCENT)

HSFR $=100 \times \mathrm{HSE} / \mathrm{EHL}$

SPACE HEATING SUBSYSTEM ELECTRICAL ENERGY SAVINGS (BTU)

HSVE = HSE - HOPE 1 - TCEOPE [if HSE $\leq$ EHL $\times(1$ - HPFRAC)]

HPFRAC is the calculated fraction of the load that would be carried by the air-to-air heat pump if there were no solar system

HSVE $=$ EHL $(1-$ HPFRAC $)+\frac{\text { FSOL } \times \text { [HSE - EHL }(1-\text { HPFRAC)] }}{\text { (HPCOPCTA) }}$ 


$$
\begin{aligned}
& + \text { FSAHP } \times\left(\frac{\text { HSE }- \text { EHL }(1-\text { HPFRAC })}{\text { (HPCOP(TA) }}-\frac{\text { HSE }- \text { EHL }(1-\text { HPFRAC })}{\text { HPCOP(TWATER })}\right) \\
& +.25 \times 56.8833 \times \text { THEAT } \times \text { [HSE - EHL }(1-\text { HPFRAC })] \\
& - \text { HOPE } 1-\text { TCEOPE }
\end{aligned}
$$

HOT WATER CONSUMED (GALLONS)

HWCSM $=\Sigma W D 301 \times \Delta \tau$

SOLAR ENERGY TO HOT WATER (BTU)

HWSE $=\Sigma[$ M300 $\times$ H $(\mathrm{T} 300, \mathrm{~T} 301)] \times \Delta \tau$

HOT WATER SUBSYSTEM OPERATING ENERGY (BTU)

HWOPE $-56.0833 \times \Sigma$ EP300 $\times \Delta \tau$

SOLAR SPECIFIC DHW OPERATING ENERGY

HWOPE $1=$ HWOPE

HOT WATER AUXILIARY ELECTRIC ENERGY (BTU)

HWAE $=56.8833 \times \Sigma \mathrm{EP} 301 \times \Delta \tau$

HOT WATER AUXILIARY THERMAL ENERGY (BTU)

$$
\text { HWAT }=\text { HWAE }
$$

HOT WATER LOAD (BTU)

HWL $=$ HWAT + HWSE

HOT WATER DEMAND

HWDM $=\Sigma$ M301 $\times$ H $(\mathrm{T} 305, \mathrm{~T} 304)$

HOT WATER SOLAR FRACTION (PERCENT)

HWDSFR = FRACTION OF DELIVERED HOT WATER LOAD DERIVED FROM SOLAR SOURCES AFTER PRORATING STORAGE LOSSES TO SOLAR AND AUXILIARY SOURCES

HOT WATER ELECTRICAL ENERGY SAVINGS (BTU)

HWSVE = HWSE - HWOPE

HOT WATER SOLAR FRACTION

HWSFR $=$ HWSE $/$ HWL 
SERVICE SUPPLY WATER TEMPERATURE ( $\left.{ }^{\circ} \mathrm{F}\right)$

$$
\begin{aligned}
\mathrm{TSW}= & (1 / 60) \times \sum \mathrm{T} 304 \times \Delta \tau \\
& \text { when water is being drawn }
\end{aligned}
$$

SERVICE HOT WATER TEMPERATURE ( $\left.{ }^{\circ} \mathrm{F}\right)$

$$
\mathrm{THW}=(1 / 60) \times \Sigma \mathrm{T} 3005 \times \Delta \tau
$$

INCIDENT SOLAR ENERGY ON COLLECTOR ARRAY (BTU)

$$
\text { SEA = CLAREA } \times \text { SE }
$$

COLLECTED SOLAR ENERGY (BTU)

$$
\text { SEC = SECA/CLAREA }
$$

COLLECTOR ARRAY EFFICIENCY

$$
\text { CLEF = SECA } / \text { SEA }
$$

OPERATIONAL COLLECTOR ARRAY EFFICIENCY

$$
\text { CLEFOP }=\text { SECA } / \text { SEOP }
$$

STORAGE PERFORMANCE

$$
\text { STPER = STORAGE TANK SURFACE AREA } \times \text { (TST - T203) }
$$

CHANGE IN STORED ENERGY (BTU)

$$
\begin{aligned}
& \text { STECH }=\text { STECHI }- \text { STECH }_{p} \\
& \text { where the subscript } p \text { refers to a prior reference value }
\end{aligned}
$$

STORAGE LOSS

$$
\text { STLOSS = STEI - STEO }- \text { STECH }
$$

STORAGE EFFICIENCY

$$
\text { STEFF }=(\text { STECH }+ \text { STEO }) / \text { STEI }
$$

SOLAR ENERGY TO LOAD SUBSYSTEM (BTU)

$$
\text { SEL = HSE + HWSE }
$$

ECSS SOLAR CONVERSION EFFICIENCY

$$
\text { CSCEF }=\text { SEL } / \text { SEA }
$$


THERMODYNAMIC CONVERSION EQUIPMENT LOAD

$$
\text { TCEL }=\text { HLHP }
$$

TCE INPUT

TCEC $=$ HAE 1

TCE COEFFICIENT OF PERFORMANCE

TCECOP $=$ TCEL $/$ TCEI

SYSTEM LOAD (BTU)

SYSL $=$ HWL + HL

SOLAR FRACTION OF SYSTEM IOAN

SFR $=($ HWSFR $\times$ HWL + HSFR $\times H L) / S Y S L$

AUXILIARY THERMAL ENERGY TO LOADS (BTU)

$$
\mathrm{AXT}=\text { HAT + HWAT }
$$

AUXILIARY ELECTRICAL ENERGY TO LOADS (BTU)

$$
\mathrm{AXE}=\mathrm{HWAE}
$$

SYSTEM OPERATING ENERGY (BTU)

$$
\text { SYSOPE }=\text { CSOPE }+ \text { HWUPE + IIOPE }
$$

TUTAL ENERGY CONSUMED (BTU)

$$
\mathrm{TECSM}=\mathrm{AXE}+\mathrm{SYSOPE}+\mathrm{SECA}
$$

TOTAL ELECTRICAL ENERGY SAVINGS (BTU)

$$
\text { TSVE }=\text { HWSVE + HSQVE }- \text { SC.OPE }
$$

SYSTEM PERFORMANCE FACTOR

$$
\text { SYSPF }=\text { SYSL } /[(\text { AXE }+ \text { SYSOPE }) \times 3.33]
$$




\section{CALCULATION OF PREDICTED VALUES}

The f-Chart 4.0 program is used by the NSDN to estimate performance of the solar system. The f-Chart program was developed by the Solar Energy laboratory, University of Wisconsin-Madison, and was originally intended to be used as a design tool. This program has been modified to use measured weather data and measured subsystem loads and losses in place of average long-term weather data and ASHRAE building heat loss (UA) estimated loads. The results help to determine if the system is performing well.

Ref:

(1) Solar Engineering of Thermal Processes, John A. Duffie and William A. Beckman, Wiley Interscience, NY (1980).

(2) FCHART, A Design Program for Solar Heating Systems, Version 4.0, EES Report 50, J. C. Mitchell, J. E. Braun, W. E. Buckles, S. A. Klein, W. A. Beckman, D. M. Uteinger, J. Sheridan, Solar Energy Laboratory, University of Wisconsin-Madison, Madison, Wisconsin (1980).

SYSTEM PERFORMANCE SUMMARY (F-CHART, VERSION 4.0)*

SUMMERWOD ASSOCIATES, HOUSE M

JUNE 1980 THROUGH MAY 1981

(All values in million BTU, unless otherwise indicated)

\begin{tabular}{|c|c|c|c|c|c|c|c|c|c|c|}
\hline & KT & TA $\left({ }^{\circ} \mathrm{F}\right)$ & SHLOAD & HWLOAD & QU & QLoss & DRLTE & FNP (z) & FOKW (x) & FN (X) \\
\hline Jox & 14.95 & 66 & 0.00 & 0.65 & 1.13 & 0.55 & 0.04 & 82 & 82 & 0 \\
\hline JUL & 17.52 & 75 & 0.00 & 0.66 & 1.48 & 0.63 & 0.10 & 96 & 96 & 0 \\
\hline AUG & 15.92 & 75 & 0.00 & 0.51 & 1.16 & 0.68 & 0.00 & 49 & 49 & 0 \\
\hline SEP & 17.46 & 67 & 0.00 & 0.56 & 1.68 & 0.65 & 0.00 & 1.00 & 1.00 & 0 \\
\hline OCT & 13.03 & 52 & 0.77 & 0.46 & 1.19 & 0.55 & -0.33 & 79 & 44 & 0 \\
\hline HOV & 11.85 & 42 & 6.14 & 0.64 & 3.69 & 0.17 & -0.48 & 76 & 28 & 18 \\
\hline DBC & 11.45 & 29 & 9.52 & 0.84 & 5.08 & -0.03 & 0.00 & 53 & 0 & 38 \\
\hline JAN & 12.22 & 2.2 & 11.46 & 0.61 & 5.23 & -0.04 & 0.00 & 51 & 0 & 41 \\
\hline FBB & 11.13 & 36 & 4.54 & 0.35 & 4.13 & 0.05 & 0.17 & 86 & 13 & 7 \\
\hline MAR & 15.69 & 38 & 5.40 & 0.41 & 5.36 & 0.07 & -0.17 & 94 & 16 & 0 \\
\hline APR & 15.01 & 50 & 0.44 & 0.42 & 3.12 & 0.30 & 0.80 & 64 & 26 & 0 \\
\hline MAY & 17.09 & 59 & 0.14 & 0.65 & 1.11 & 0.62 & -0.14 & 80 & 76 & 0 \\
\hline TOTAL & 173.32 & - & 38.41 & 6.76 & 34.37 & 4.20 & 0.00 & - & - & $\cdot$ \\
\hline AVBRAGR & 14.44 & 51 & 3.20 & 0.56 & 2.86 & 0.35 & 0.00 & 68 & 45 & 23 \\
\hline \multicolumn{11}{|c|}{ PURCHASED EKERGY SUROARY } \\
\hline & \multirow{3}{*}{\multicolumn{2}{|c|}{. }} & & $\underline{\text { GAS }}$ & \multicolumn{2}{|c|}{ ELECTRIC } & OIL & TOTAL & & \\
\hline & & & USE (RATU) & 0.0 & \multicolumn{2}{|c|}{14.53} & 0.0 & 14.53 & & \\
\hline & & & $\cos t(\$)$ & 0.0 & \multicolumn{2}{|c|}{91.57} & 0.0 & $92: 57$ & & \\
\hline
\end{tabular}

-See next page for glossary of f-Chert Version. 4.0 terns.

*See next page for glossary of f-Chart Version 4.0 terms. 


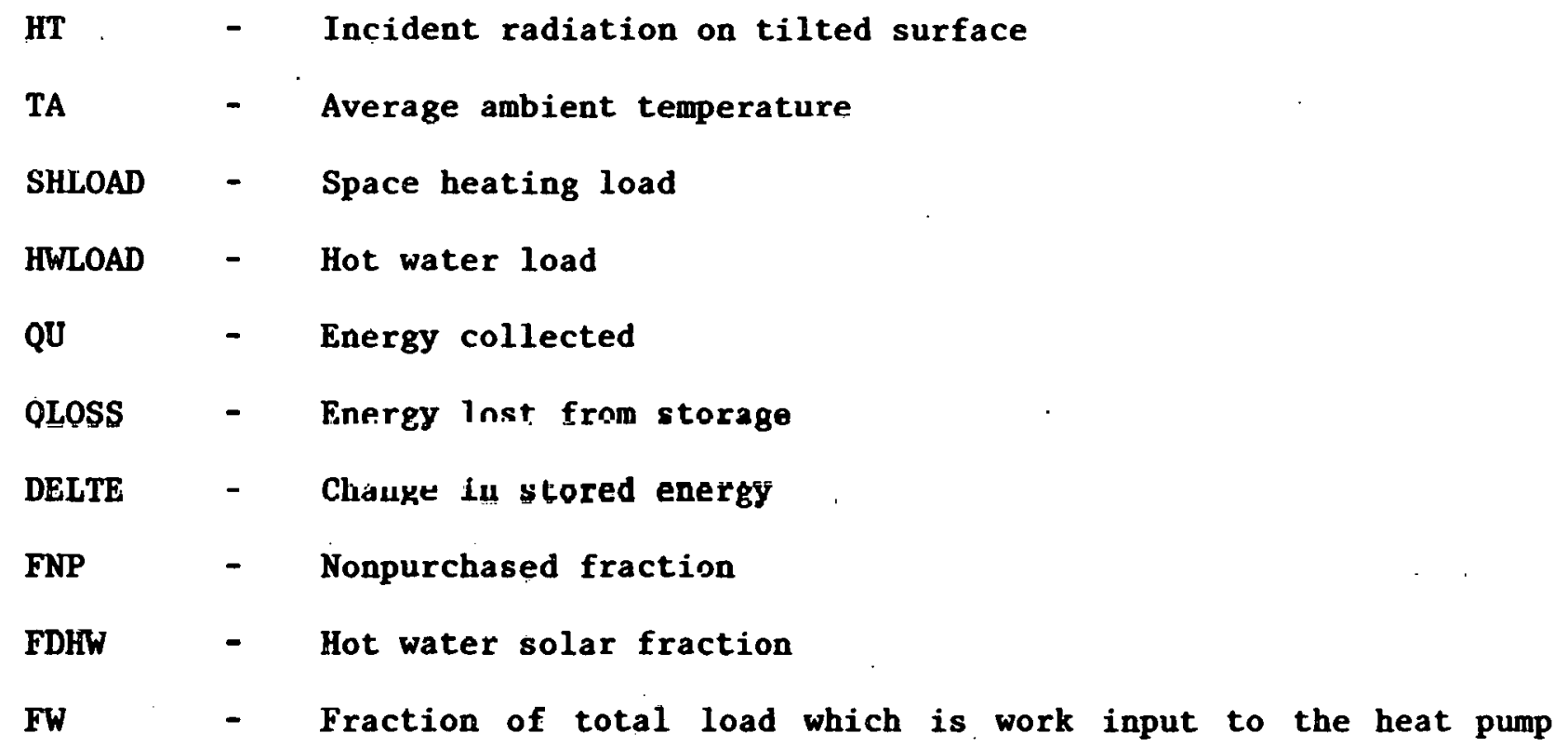


APPENDIX F

METEOROLOGICAL CONDITIONS 
SUMERWOOD ASSOCIATES, HOUSE M LONG-TERM WEATHER DATA

COLLECTOR TILT: 50 DEGREES LATITUDE : 41 DEGREES
LOCATION: OLD SAYBROOK, CONNECTICUT COLLECTOR AZIMUTH: - 12 DEGREES

\begin{tabular}{llrrrrrrr} 
MONTH & HOBAR & HBAR & KBAR & RBAR & SBAR & HDD & CDD & TBAR \\
\hline JUN & 3,643 & 1,792 & 0.49190 & 0.794 & 1,423 & 24 & 111 & 68 \\
JUL & 3,543 & 1,751 & 0.49431 & 0.817 & 1,431 & 0 & 273 & 74 \\
AUG & 3,165 & 1,552 & 0.49044 & 0.920 & 1,428 & 0 & 241 & 73 \\
SEP & 2,574 & 1,254 & 0.48704 & 1.112 & 1,394 & 42 & 87 & 67 \\
OCT & 1,907 & 936 & 0.49096 & 1.408 & 1,319 & 261 & 6 & 57 \\
NOV & 1,369 & 571 & 0.41732 & 1.675 & 957 & 570 & 0 & 46 \\
DEC & 1,134 & 442 & 0.39016 & 1.831 & 810 & 967 & 0 & 34 \\
JAN & 1,261 & 535 & 0.42397 & 1.781 & 952 & 1,079 & 0 & 30 \\
FEB & 1,730 & 774 & 0.44756 & 1.481 & 1,146 & 955 & 0 & 31 \\
MAR & 2,343 & 1,084 & 0.46255 & 1.199 & 1,300 & 840 & 0 & 38 \\
APR & 2,990 & 1,427 & 0.47717 & 0.981 & 1,399 & 498 & 0 \\
MAY & 3,452 & 1,678 & 0.48591 & 0.847 & 1,421 & 225 & 17
\end{tabular}

\section{LEGEND:}

HOBAR - Monthly average daily extraterrestrial radiation (ideal) in BTU/day- $\mathrm{ft}^{2}$.

HBAF - Monthly average daily radiation (actual) in $B T U / d a y-f t^{2}$.

KBAF - Ratio of HBAR to HOBAR.

RBAF - Ratio of monthly average daily radiation on tilted surface to that on a horizontal surface for each month (i.e., multiplier obtained by tilting).

SBAF - Monthly average daily radiation on a tilted surface (i.e., RBAR $x$ HBAR) in BTU/day- $\mathrm{ft}^{2}$.

HDD - Number of heating degrees-days per month.

CDD - Number of cooling degrees-days per month.

TBAR - Average ambient temperature in degrees Fahrenheit. 
MONTHLY REPORT: SUMEERWOOD ASSOCIATES, HOUSE M JNE 1980 ENVIRONRENTAL SUMMARY

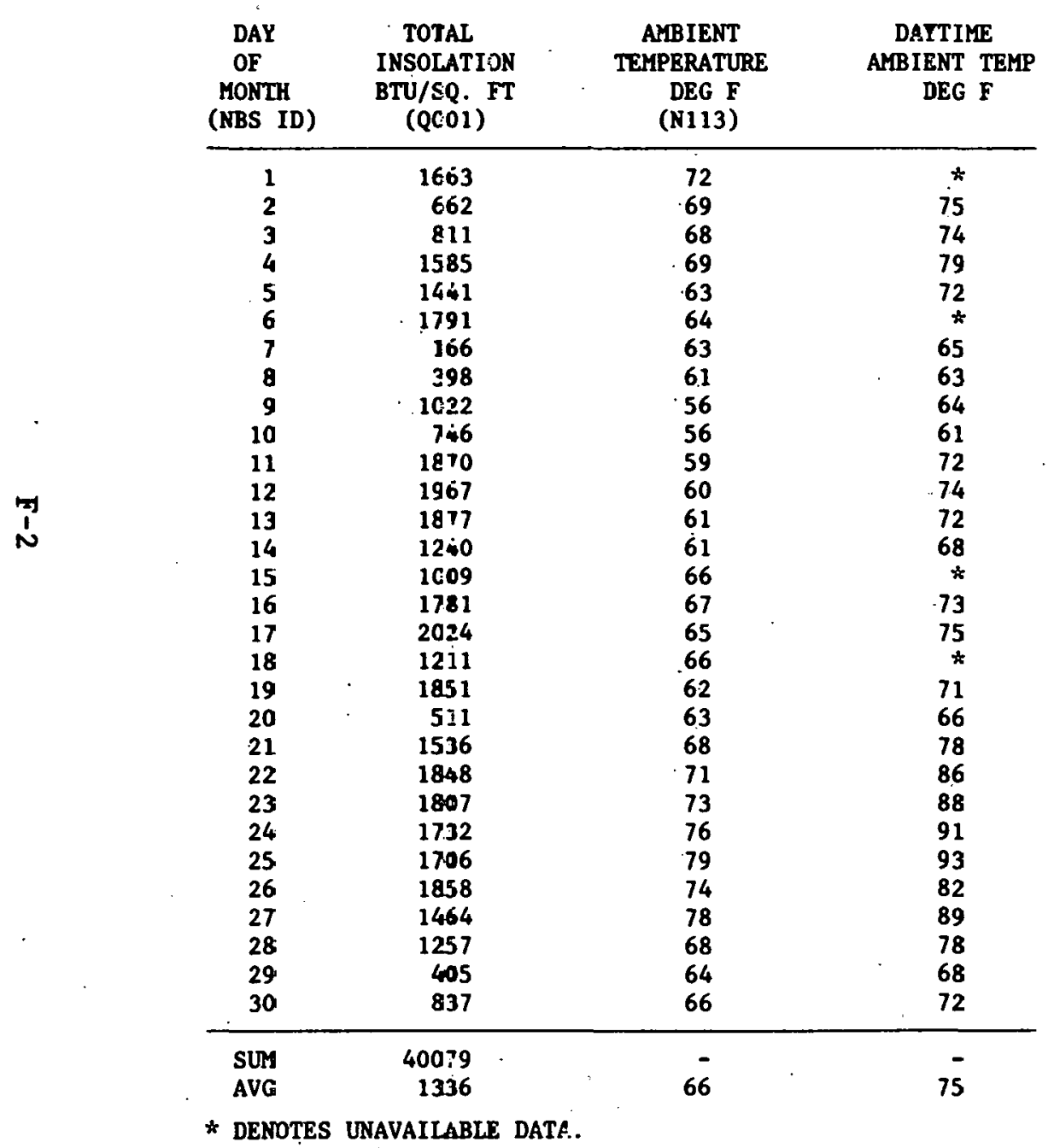

MONTHLY REPORT: SUMMERWOOD ASSOCIATES, HOUSE M

\section{JULY 1980 . ENVIRONMENTAL SUMMARY}

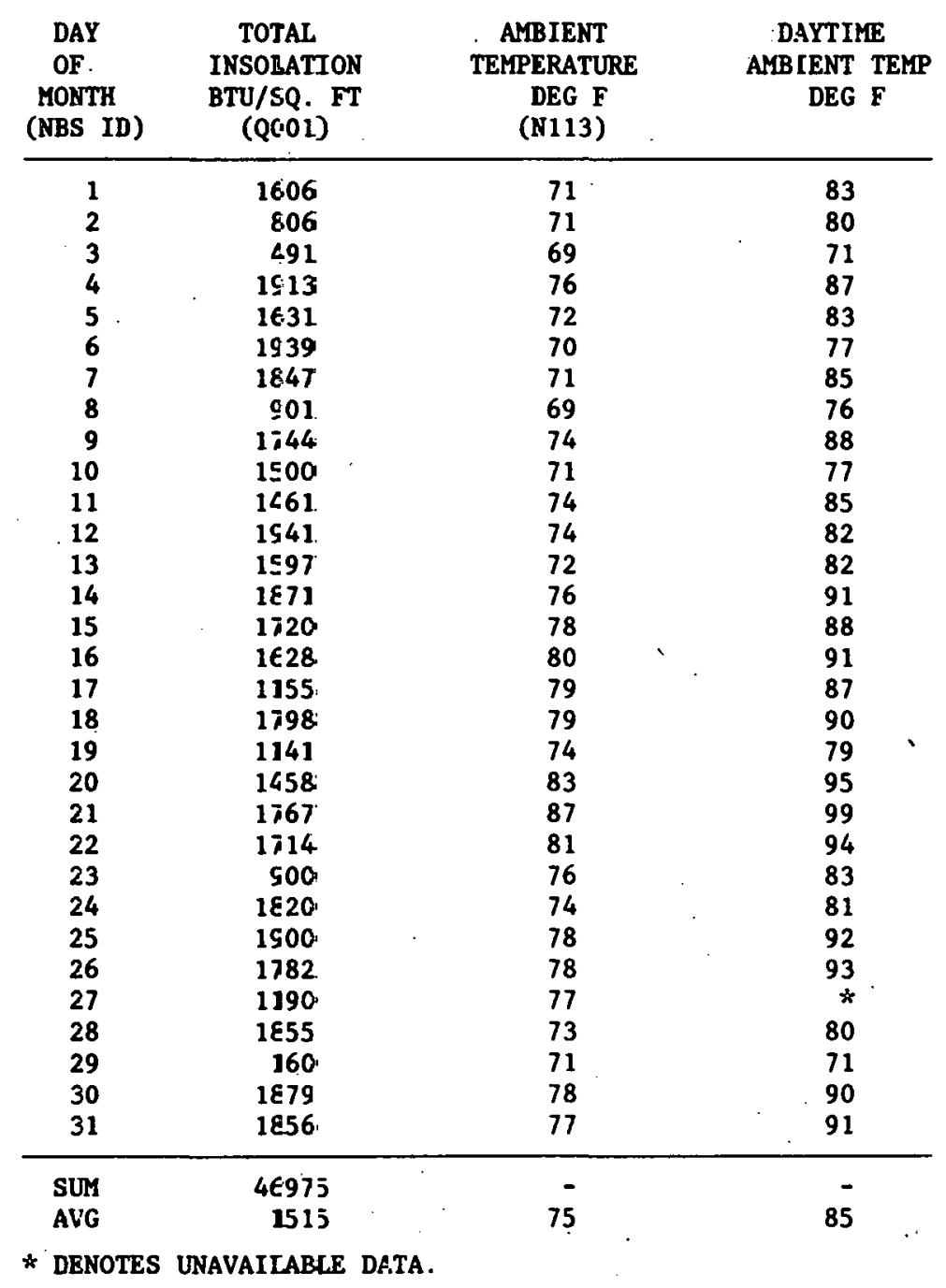


MONTHLY REPORT: SUMMERWOOD ASSOCIATES, HOUSE M AUGUST 1980

\section{ENVIRONMENTAL SUMMARY}

\begin{tabular}{|c|c|c|c|}
\hline $\begin{array}{l}\text { DAY } \\
\text { OF } \\
\text { MONTH } \\
\text { (NBS ID) }\end{array}$ & $\begin{array}{c}\text { TOTAL } \\
\text { INSOLATION } \\
\text { BTU/SQ. FT } \\
\text { (QO01) }\end{array}$ & $\begin{array}{c}\text { AMBIENT } \\
\text { TEMPERATURE } \\
\text { DEG F } \\
\text { (甘113) }\end{array}$ & $\begin{array}{c}\text { DAYTIME } \\
\text { AMBIBNT TEMP } \\
\text { DEG F }\end{array}$ \\
\hline $\begin{array}{r}1 \\
2 \\
3 \\
4 \\
5 \\
6 \\
7 \\
8 \\
9 \\
10 \\
11 \\
12 \\
13 \\
14 \\
15 \\
16 \\
17 \\
18 \\
19 \\
20 \\
21 \\
22 \\
23 \\
24 \\
25 \\
26 \\
27 \\
28 \\
29 \\
30 \\
31\end{array}$ & $\begin{array}{r}1291 \\
1611 \\
1582 \\
1441 \\
1665 \\
1282 \\
1843 \\
1536 \\
1725 \\
1839 \\
759 \\
1304 \\
1707 \\
716 \\
874 \\
1534 \\
1961 \\
1791 \\
588 \\
752 \\
658 \\
1470 \\
2009 \\
1936 \\
1555 \\
1993 \\
1712 \\
1029 \\
512 \\
643 \\
1370 \\
\therefore\end{array}$ & $\begin{array}{l}76 \\
79 \\
79 \\
82 \\
78 \\
82 \\
81 \\
82 \\
83 \\
75 \\
73 \\
77 \\
77 \\
71 \\
76 \\
68 \\
69 \\
71 \\
71 \\
67 \\
65 \\
68 \\
71 \\
75 \\
76 \\
74 \\
80 \\
87 . \\
68 \\
68 \\
72 \\
78\end{array}$ & $\begin{array}{l}85 \\
93 \\
89 \\
94 \\
86 \\
94 \\
94 \\
96 \\
92 \\
85 \\
74 \\
87 \\
89 \\
79 \\
81 \\
76 \\
81 \\
88 \\
75 \\
71 \\
69 \\
74 \\
81 \\
90 \\
89 \\
79 \\
95 \\
87 \\
71 \\
76 \\
89\end{array}$ \\
\hline $\begin{array}{l}\text { SUI } \\
\text { AVG }\end{array}$ & $\begin{array}{l}42686 \\
1377\end{array}$ & $\therefore \quad 75$ & 84 \\
\hline
\end{tabular}

MONTHLY REPORT: SUMMERWOOD ASSOCIATES, HOUSE M SEPTEMBER 1980

. ENVIRONMENTAL SUMMARY

\begin{tabular}{|c|c|c|c|}
\hline $\begin{array}{l}\text { DAY } \\
\text { OF } \\
\text { MONTH } \\
\text { (NBS ID) }\end{array}$ & $\begin{array}{c}\text { TOTAL } \\
\text { INSOLATION } \\
\text { BTU/SQ. FT } \\
(\mathrm{Q} 001)\end{array}$ & $\begin{array}{c}\text { AMBIENT } \\
\text { TEMPERATURE } \\
\text { DEG F } \\
\text { (N113) }\end{array}$ & $\begin{array}{l}\text { DAYTIYE } \\
\text { AMBIENT TEMP } \\
\text { DEG F }\end{array}$ \\
\hline $\begin{array}{l}1 \\
2 \\
3 \\
4 \\
5 \\
6 \\
7 \\
8 \\
9 \\
10 \\
11 \\
12 \\
13 \\
14 \\
15 \\
16 \\
17 \\
18 \\
19 \\
20 \\
21 \\
22 \\
23 \\
24 \\
25 \\
26 \\
27 \\
28 \\
29 \\
30\end{array}$ & $\begin{array}{r}1478 \\
1928 \\
2092 \\
2136 \\
808 \\
1969 \\
1972 \\
2145 \\
2075 \\
1914 \\
2139 \\
1061 \\
995 \\
1138 \\
959 \\
2079 \\
923 \\
1179 \\
1956 \\
1848 \\
1502 \\
1451 \\
1357 \\
1642 \\
382 \\
1545 \\
1954 \\
1812 \\
1377 \\
1407\end{array}$ & $\begin{array}{l}78 \\
80 \\
73 \\
69 \\
73 \\
75 \\
69 \\
65 \\
66 \\
66 \\
67 \\
66 \\
67 \\
75 \\
64 \\
60 \\
66 \\
67 \\
60 \\
67 \\
75 \\
78 \\
74 \\
57 \\
57 \\
62 \\
51 \\
58 \\
55 \\
58\end{array}$ & $\begin{array}{l}89 \\
92 \\
83 \\
80 \\
81 \\
87 \\
81 \\
80 \\
76 \\
74 \\
83 \\
75 \\
71 \\
86 \\
66 \\
69 \\
77 \\
72 \\
75 \\
79 \\
86 \\
90 \\
86 \\
64 \\
60 \\
75 \\
61 \\
75 \\
59 \\
65\end{array}$ \\
\hline $\begin{array}{l}\text { SUI } \\
\text { AVG }\end{array}$ & $\begin{array}{r}47235 \\
1574\end{array}$ & $\therefore 67$ & 77 \\
\hline
\end{tabular}


MONTHLY REPORT: SUMMERWOOD ASSOCIATES, HOUSE M OCTOBER 1980 ENVIROMMENTAL SUMMAFY

\begin{tabular}{|c|c|c|c|}
\hline $\begin{array}{l}\text { DAY } \\
\text { OE } \\
\text { MONTH } \\
\text { (NBS ID) }\end{array}$ & $\begin{array}{l}\text { TOTAL } \\
\text { INSOLATION } \\
\text { BTU/SQ. FT } \\
\text { (COOL1) }\end{array}$ & $\begin{array}{c}\text { AMBIENT } \\
\text { TEMPERATURE } \\
\text { DEG F } \\
\text { (N113) }\end{array}$ & $\begin{aligned} \text { DAYTIME } \\
\text { AMBIENT TEMP } \\
\text { DEG }\end{aligned}$ \\
\hline $\begin{array}{r}1 \\
2 \\
3 \\
4 \\
5 \\
6 \\
7 \\
8 \\
9 \\
15 \\
11 \\
12 \\
13 \\
14 \\
15 \\
10 \\
17 \\
18 \\
19 \\
26 \\
28 \\
22 \\
23 \\
24 \\
25 \\
26 \\
21 \\
28 \\
25 \\
3 C \\
31\end{array}$ & $\begin{array}{r}1076 \\
580 \\
167 \\
1822 \\
815 \\
790 \\
1039 \\
1369 \\
1941 \\
2053 \\
113 \\
1446 \\
585 \\
2731 \\
579 \\
1140 \\
1543 \\
84 \\
1122 \\
1740 \\
338 \\
1394 \\
1984 \\
1773 \\
16 \\
866 \\
1979 \\
170 \\
1781 \\
836 \\
1794\end{array}$ & $\begin{array}{l}62 \\
64 \\
59 \\
61 \\
54 \\
52 \\
50 \\
58 \\
58 \\
48 \\
62 \\
54 \\
44 \\
45 \\
49 \\
59 \\
65 \\
65 \\
59 \\
53 \\
49 \\
47 \\
39 \\
44 \\
52 \\
49 \\
48 \\
48 \\
42 \\
39 \\
47\end{array}$ & $\begin{array}{r}70 \\
66 \\
61 \\
72 \\
64 \\
60 \\
60 \\
66 \\
66 \\
56 \\
66 \\
65 \\
52 \\
56 \\
58 \\
67 \\
77 \\
67 \\
64 \\
64 \\
58 \\
56 \\
49 \\
.52 \\
52 \\
52 \\
56 \\
51 \\
53 \\
50 \\
57\end{array}$ \\
\hline $\begin{array}{l}\text { SUM } \\
\text { AVG }\end{array}$ & $\begin{array}{r}34932 \\
1127\end{array}$ & $5 \overline{2}$ & 60 \\
\hline
\end{tabular}

MONTHLY REPOET: SIMMERWOOD ASSOCIATES, HOUSE M NOVEMBER 1980 ENVIRONMENTAL SUMMARY

\begin{tabular}{|c|c|c|c|}
\hline $\begin{array}{l}\text { DAY } \\
\text { OF } \\
\text { WONTH } \\
\text { (NBS ID) }\end{array}$ & $\begin{array}{c}\text { TJTAL } \\
\text { INSJLATION } \\
\text { BTU/SI. FT } \\
(20.11)\end{array}$ & $\begin{array}{c}\text { AMBIENT } \\
\text { TEMPERATURE } \\
\text { DEG F } \\
\text { (N113) }\end{array}$ & $\begin{array}{c}\text { DAYTIME } \\
\text { AMBIENT TEMP } \\
\text { DEG } \mathrm{F}\end{array}$ \\
\hline 1 & $7 \div 7$ & 47 & 53 \\
\hline 2 & 1898 & 38 & 48 \\
\hline 3 & 1692 & 40 & 49 \\
\hline 4 & 426 & 54 & 60 \\
\hline 5 & i 306 & 48 & 55 \\
\hline 6 & 1727 & 43 & 51 \\
\hline 7 & 1587 & 54 & 63 \\
\hline 8 & 1254 & 51 & 62 \\
\hline 9 & 344 & 42 & 49 \\
\hline 10 & 763 & 42 & 51 \\
\hline 11 & $=399$ & 36 & 39 \\
\hline 12 & $: 4: 6$ & 38 & 44 \\
\hline 13 & $=050$ & 44 & 50 \\
\hline 14 & 994 & 54 & 63 \\
\hline 15 & 333 & 41 & 44 \\
\hline 16 & 1801 & 36 & 42 \\
\hline 17 & $12 \approx 2$ & 34 & 41 \\
\hline 18 & 1616 & 34 & 35 \\
\hline 19 & 1826 & 32 & 38 \\
\hline 20 & 1245 & 35 & 47 \\
\hline 21 & $13 \mathrm{CO}$ & 42 & 55 \\
\hline 22 & 1591 & 41 & 48 \\
\hline 23 & 717 & 41 & 49 \\
\hline 24 & 58 & 49 & 50 \\
\hline 25 & 959 & 47 & 51 \\
\hline 26 & 1732 & 37 & 44 \\
\hline 27 & 393 & 35 & 39 \\
\hline 28 & 0 & 45 & 45 \\
\hline 29 & 417 & 40 & 44 \\
\hline 30 & 1407 & 40 & 47 \\
\hline SUM & 31770 & - & - \\
\hline AVG & 1059 & 42 & 48 \\
\hline
\end{tabular}


MONTHLY REPORT: SUMMERWOOD ASSOCIATES, HOUSE M DECEMBER : 1980 ENVIRONMENTAL SUMMARY

\begin{tabular}{|c|c|c|c|}
\hline $\begin{array}{l}\text { DAY } \\
\text { OF } \\
\text { MONTH } \\
\text { (NBS ID) }\end{array}$ & $\begin{array}{c}\text { TOTAL } \\
\text { INSOLATION } \\
\text { BTU/SQ. FT } \\
\text { (Q001) }\end{array}$ & $\begin{array}{c}\text { AMBIENT } \\
\text { TEMPERATURE } \\
\text { DEG F } \\
\text { (N113) }\end{array}$ & $\begin{array}{c}\text { DAYTIME } \\
\text { AMBIENT TEMP } \\
\text { DEG }\end{array}$ \\
\hline 1 & 1070 & 46. & 53 \\
\hline 2 & 590 & 48 & 53 \\
\hline 3 & 1168 & 32 & 33 \\
\hline 4 & 1789 & 25 & 31 \\
\hline 5 & 1769 & 27 & 34 \\
\hline 6 & 1663 & 30 & 37 \\
\hline 7 & 1220 & 36 & 48 \\
\hline 8 & 655 & 46 & 53 \\
\hline 9 & 591 & 45 & 46 \\
\hline 10 & 631 & 37 & 41 \\
\hline 11 & 1708 & 25 & 26 \\
\hline 12 & 1286 & 32 & 38 \\
\hline 13 & 874 & 42 & 49 \\
\hline 14 & 715 & 26 & 34 \\
\hline 15 & 821 & 24 & 30 \\
\hline 16 & 108 & 33 & 36 \\
\hline 17 & 1593 & 23 & 26 \\
\hline 18 & 355 & 28 & 36 \\
\hline 19 & 244 & 30 & 36 \\
\hline 20 & 1532 & 14 & 24 \\
\hline 21 & 1648 & 18 & 31 \\
\hline 22 & 1346 & 23 & 30 \\
\hline 23 & 1 & 31 & 31 \\
\hline 24 & 426 & 29 & 37 \\
\hline 25 & 1786 & 0 & -1 \\
\hline 26 & $\$ 129$ & 12 & 25 \\
\hline 27 & 990 & 23 & 27 \\
\hline 28 & 118 & 34 & 37 \\
\hline 29 & 448 & 40 & 44 \\
\hline 30 & 1286 & 34 & 40. \\
\hline 31 & 1129 & 17 & 23 \\
\hline SUM & 30.691 & - & - \\
\hline AVG & 990 & 29 & 35 \\
\hline
\end{tabular}

MONTHLY REPORT: SUMMERWOOD ASSOCIATES, HOUSE M JANUARY 1981 ENVIRONMENTAL SUMMARY

\begin{tabular}{|c|c|c|c|}
\hline $\begin{array}{l}\text { DAY } \\
\text { DF } \\
\text { MONTH } \\
\text { (NBS ID) }\end{array}$ & $\begin{array}{c}\text { TOTAL } \\
\text { INSOLATION } \\
\text { BTU/SQ. FT } \\
(Q 001)\end{array}$ & $\begin{array}{c}\text { AMBIENT } \\
\text { TEMPERATURE } \\
\text { DEG F } \\
\text { (N113) }\end{array}$ & $\begin{array}{l}\text { DAYTIME } \\
\text { AMBIENT TEMP } \\
\text { DEG } \mathrm{F}\end{array}$ \\
\hline 1 & 219 & 23 & 26 \\
\hline 2 & 506 & 25 & 32 \\
\hline 3 & 149 & 11 & 13 \\
\hline 4 & 1237 & 4 & 9 \\
\hline 5 & 1506 & 14 & 24 \\
\hline 6 & 854 & 26 & 34 \\
\hline 7 & 241 & 30 & 34 \\
\hline 8 & 1739 & 13 & 21 \\
\hline 9 & 992 & 14 & 27 \\
\hline 10 & 1084 & 17 & 22 \\
\hline 11 & 1767 & 8 & 16 \\
\hline 12 & 1776 & 3 & 11 \\
\hline 13 & 1781 & 10 & 18 \\
\hline 14 & 313 & 17 & 24 \\
\hline 15 & 134 & 22 & 27 \\
\hline 16 & 171 & 24 & 27 \\
\hline 17 & 495 & 19 & 22 \\
\hline 18 & 1367 & 19 & 27 \\
\hline 19 & 1456 & 34 & 42 \\
\hline 20 & 1217 & 30 & 39 \\
\hline 21 & 1675 & 22 & 32 \\
\hline 22 & 285 & 24 & 33 \\
\hline 23 & 881 & 33 & 43 \\
\hline 24 & 1382 & 30 & 37 \\
\hline 25 & 1856 & 27 & 37 \\
\hline 26 & 357 & 36 & 43 \\
\hline 27 & 1510 & 38 & 49 \\
\hline 28 & 710 & 30 & 39 \\
\hline 29 & 1227 & 28 & 36 \\
\hline 30 & 1923 & 20 & 29 \\
\hline 31 & 1970 & 21 & 30 \\
\hline SUM & 32780 & - & - \\
\hline AVG & 1057 & 22 & 29 \\
\hline
\end{tabular}


MONTHLY REPORT:- SUMERWOD ASSOCIATES, HOUSE M FEBRUARY 1981 ENV IRONIENTAL SUMMARY

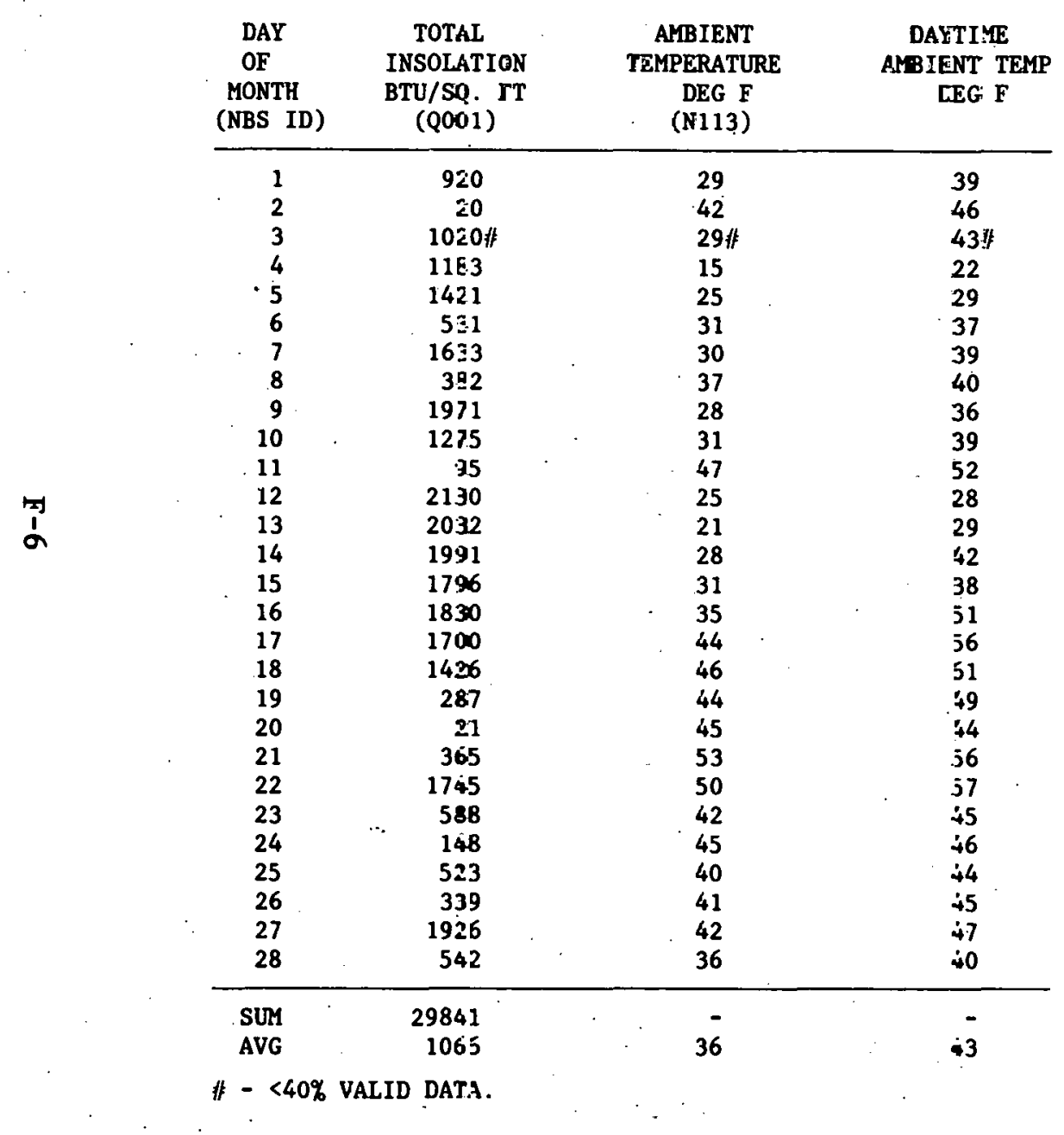

MONTHLY REPORT: SUMMERWOOD ASSOCIATES, FOUSE M MARCH 1981 ENVIROMMENTAL SUMMARY

\begin{tabular}{|c|c|c|c|}
\hline $\begin{array}{l}\text { DAY } \\
\text { OF } \\
\text { MONTH } \\
\text { (NBS ID) }\end{array}$ & $\begin{array}{l}\text { TOTAL } \\
\text { INSOLATION } \\
\text { BTU/SQ. FT } \\
\text { (Q0J1) }\end{array}$ & $\begin{array}{c}\text { AMBIENT } \\
\text { TEMPERATURE } \\
\text { DEG F } \\
\text { (N113) }\end{array}$ & $\begin{array}{c}\text { DAYTIME } \\
\text { AMBIENT TEMP } \\
\text { DEG } F\end{array}$ \\
\hline 1 & 1436 & 40 & 47 \\
\hline 2 & 343 & 36 & 43 \\
\hline 3 & 2143 & 30 & 35 \\
\hline 4 & 1758 & 31 & 39 . \\
\hline 5 & 70 & 32 & 31 \\
\hline 6 & 872 & 36 & 43 \\
\hline 7 & 327 & 35 & 38 \\
\hline $\mathbf{B}$ & 174 & 37 & 40 \\
\hline 9 & 437 & 39 & 45 \\
\hline 10 & 9.37 & 38 & 46 \\
\hline 21 & $17 \cdot 04$ & 38 & 51 \\
\hline 12 & 20131 & 37 & 48 \\
\hline 13 & 20832 & 46 & 55 \\
\hline 14 & 2118 & 31 & 33 \\
\hline 15 & 1723 & 38 & 48 \\
\hline 16 & 260 & 37 & 46 \\
\hline 17 & 1608 & 30 & 38 \\
\hline 18 & 2123 & 27 & 36 \\
\hline 19 & 1986 & 30 & 39 \\
\hline 20 & 2232 & 31 & 43 \\
\hline 21 & 835 & 34 & 40 \\
\hline 22 & 1569 & $38 \therefore$ & 50 \\
\hline 23 & 1085 & 33 & 43 \\
\hline 24 & 1347 & 39 & 53 \\
\hline 25 & 922 & 36 & 43 \\
\hline 26 & 1795 & 40 & 50 \\
\hline 27 & 1083 & 44 & 52 \\
\hline 28 & $21 \vdots 1$ & 44 & 56 \\
\hline 29 & 1906 & 51 & 63 \\
\hline 30 & 65.3 & 50 & 58 \\
\hline 31 & 205.8 & 59 & 70 \\
\hline sum & $420: 7$ & - & - \\
\hline AVG & 1357 & 38 & 46 \\
\hline
\end{tabular}


MONTHLY REPORT: SUMMERWOOD ASSOCIATES, HOUSE M APRIL 1981 ENVIRONMENTAL SUMMARY

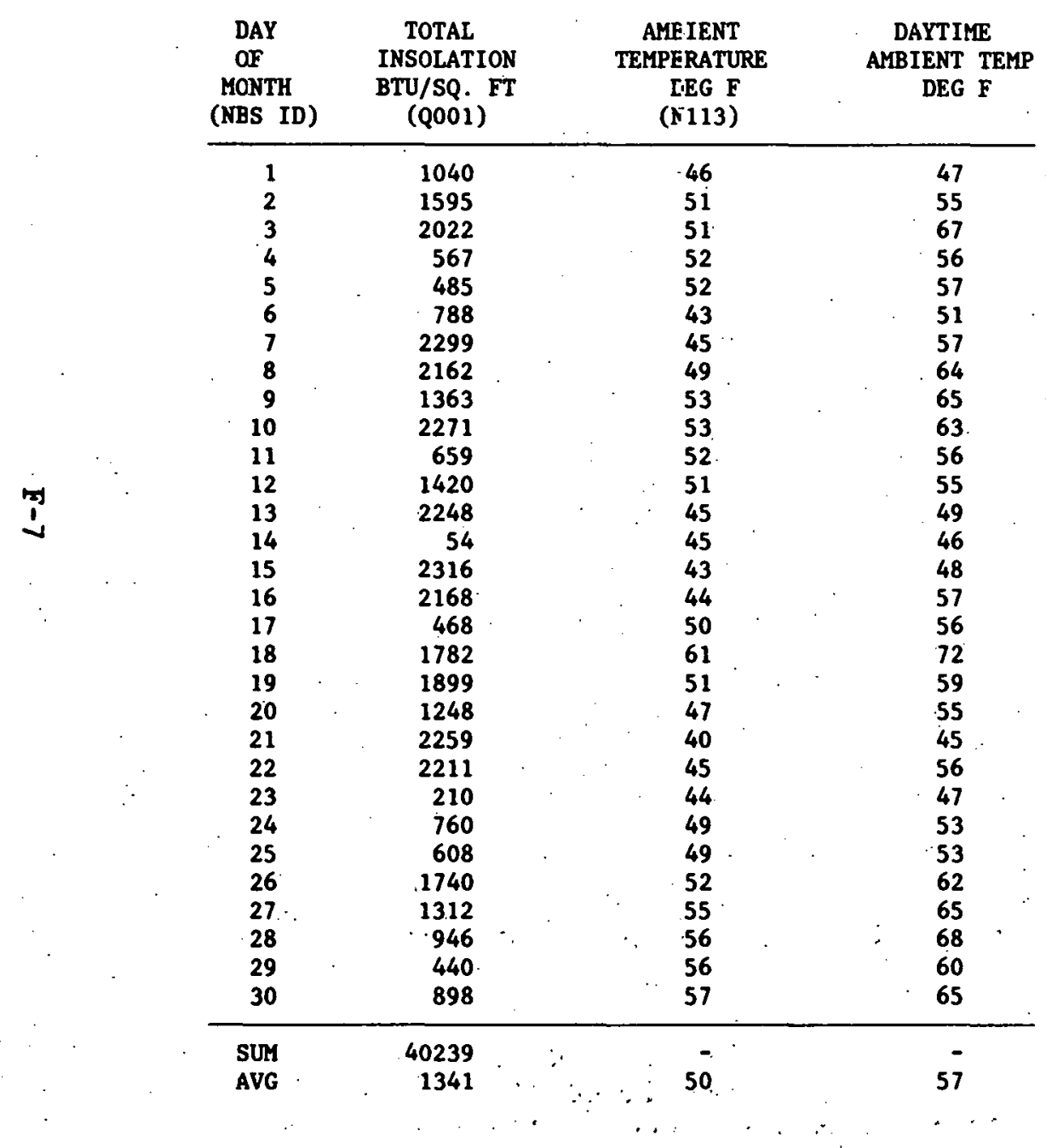

MONTHLY REPORT: SUMMERWOOD ASSOCIATES, HOUSE M MAY 1981 ENVIRONMENTAL SUMMARY

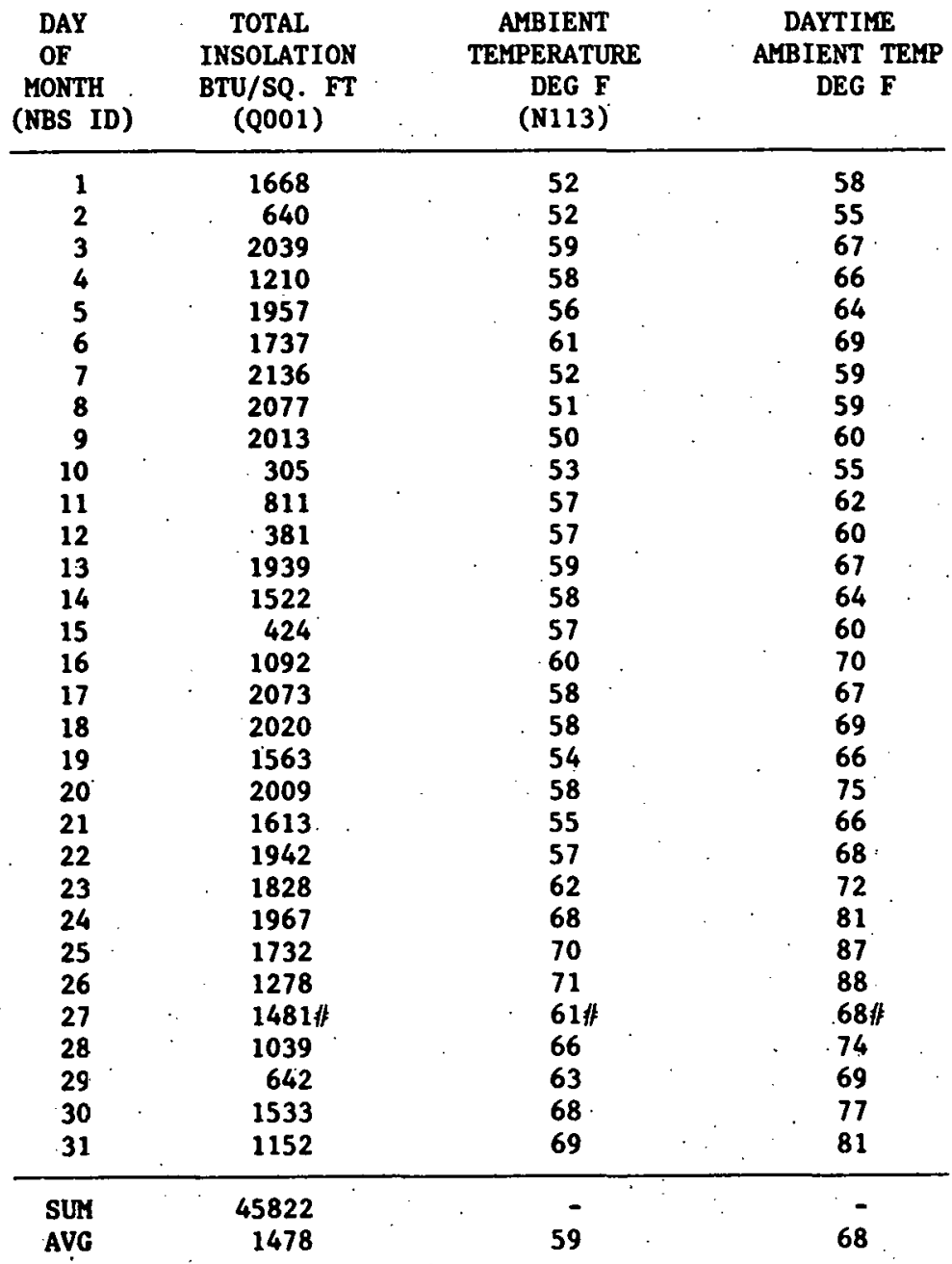

\# - $\$ 40 \%$ VALID DATA. 
APPENDIX 6

SITE HISTORY, PROBLEMS, CHANGES IN SOLAR SYSTEM

There were no problems with or changes to the solar system during the reporting period. 


\section{APPENDIX H \\ CONVERSION FACTORS}

\section{Energy Conversion Factors}

Fuel Type

\section{Distillate fuel oil 1}

Residual fuel oil ${ }^{2}$

Kerosene

Propane.

Natural gas

Electricity

\section{Energy Content}

$138,690 \mathrm{BTU} / \mathrm{gallon}$

$149,690 \mathrm{BTU} / \mathrm{gallon}$

$135,000 \mathrm{BTU} / \mathrm{gallon}$

$91,500 \mathrm{BTU} / \mathrm{gallon}$

$1,021 \mathrm{BTU} /$ cubic feet

3,413 BTU/kilowatt-hour
Fuel Source Conversion Factor

$7.21 \times 10^{-6} \mathrm{gallon} / \mathrm{BTU}$

$6.68 \times 10^{-6}$ gallon/BTU

$7.41 \times 10^{-6} \mathrm{gallion} / \mathrm{BTU}$

$10.93 \times 10^{-6} \mathrm{gallon} / \mathrm{BTU}$

$979.4 \times 10^{-6}$ cubic feet/ BTU

$292.3 \times 10^{-6} \mathrm{kwh} / \mathrm{BTU}$

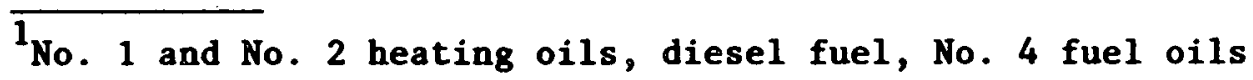

${ }^{2}$ No. 5 and No. 6 fuel oils 


\section{APPENDIX I}

\section{SENSOR TECHNOLOGY}

\section{Temperature Sensors}

Temperatures are measured by a Minco Products S53P platinum Resistance Temperature Detector (RTD). Because the resistance of platinum wire varies as a function of temperature, measurement of the resistance of a calibrated length of platinum wire can be used to accurately determine the temperature of the wire. This is the principle of the platinum RTD which utilizes a tiny coil of platinum wire encased in a copper-tipped probe to measure temperature.

Ambient temperature sensors are housed in a WeatherMeasure Radiation Shield in order to protect the probe from solar radiation. Care is taken to locate the sensor away from extraneous heat sources which could produce erroneous temperature readings. Temperature probes mounted in pipes are installed in stainless steel thermowells for physical protection of the sensor and to allow easy removal and replacement of the sensors. A thermally-conductive grease is used between the probe and the thermowell to assure faster temperature response.

A11 temperature sensors are individually calibrated at the factory. In addition, the bridge circuit is calibrated in the field using a five-point check.

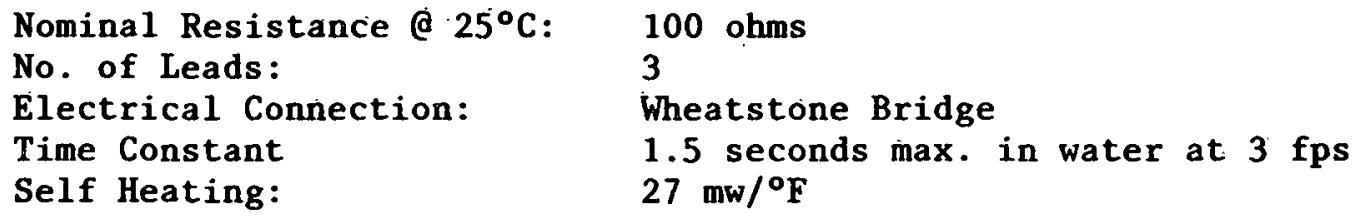

\section{WIND SENSOR}

Wind speed and direction are measured by a WeatherMeasure W102-P-DC/540 or W101-P-DC/540 wind sensor. Wind speed is measured by means of a four-bladed propeller coupled to a DC generator.

Wind direction is sensed by means of a dual-wiper 1,000-ohm long-life conductive plastic potentiometer. It is attached to the stainless steel shaft which supports and rotates with the upper body assembly.

Size:

Starting Speed:

Complete Tracking:

Maximum Speed:

Distance Constant (30 mph):

Accuracy:

Time Constant:
29-3/4"L X 30"H

$1 \mathrm{mph}$

$3 \mathrm{mph}$

$200 \mathrm{mph}$

$6.2^{\prime}$

$\pm 1 \%$ below $25 \mathrm{mph}$

$\pm 3 \%$ above $25 \mathrm{mph}$

0.145 second 


\section{HUMIDITY SENSORS}

The WeatherMeasure HMP-14U Solid State Relative Humidity Probe is used for the measurement of relative humidity. The operation of the sensor is based upon the capacitance of the polymer thin film capacitor. A one-micron-thick dielectric polymer layer absorbs water molecules through a thin metal electrode and causes capacitance change proportional to relative humidity.

$\begin{array}{ll}\text { Range: } & 0-100 \% \text { R.H. } \\ \text { Response Time: } & 1 \text { second to } 90 \% \text { humidity } \\ & \text { change at } 20^{\circ} \mathrm{C} \\ \text { Temperature Coefficient: } & 0.05 \% \text { R.H. } /{ }^{\circ} \mathrm{C} \\ \text { Accuracy: } & \pm 3 \% \text { from } 0-80 \% \text { R.H. } \\ & \pm 5-6 \% \text {. } 80-100 \% \text { R.H. } \\ \text { Sensitivity: } & 0.2 \% \text { R.H. }\end{array}$

\section{INSOLATION SENSORS}

The Eppley Model PSP pyranometer is used for the measurement of insolation. The pyranometer consists of a circular multijunction thermopile of the plated, (copper-constantan) wirewound type which is temperature compensated to render the response essentially independent of ambient temperature. The receiver is coated with Parsons' black lacquer (non-wavelength-selective absorption). The instrument is supplied with a pair of precision-ground polished concentric hemispheres of Schott optical glass transparent to light between 285 and 2800 $\mathrm{nm}$ of wavelength. The instrument is provided with a dessicator which may be readily inspected. Pyranometers designated as shadowband pyranometers are equipped: with a shadowband which may be adjusted to block out any direct solar radiation. These instruments are used for the measurement of diffuse insolation.

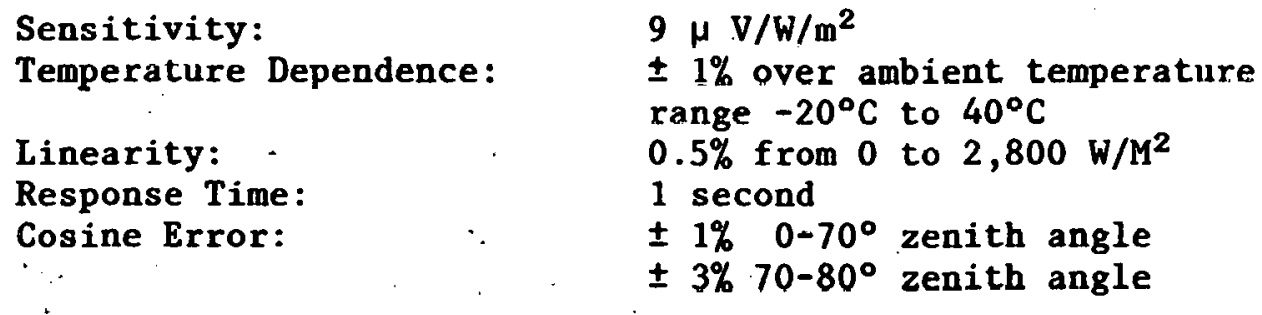

\section{LIQUID FLOW SENSORS (NON-TOTALIZING)}

The Ramapo Mark $V$ strain gauge flow meters are used for the measurement of liquid flow. The tlow meters sense the flow of the liquids by measuring the force exerted by the flow on a target suspended in the flow stream. This force is transmitted to a four active arm strain gauge bridge to provide a signal proportional to flow rate squared. The flow meters are available in a screwed end configuration, a flanged configuration, and a wafer configuration. Each flow meter is calibrated for the particular fluid being used in the application. 

Materials:
Target - 17-PH stainless steel
Body - Brass or stainless steel
Fluid Temperature:
Seals - Buna-N
Calibration Accuracy:
$-40^{\circ} \mathrm{F}$ to $250^{\circ} \mathrm{F}$
$\pm 1 \%$ ( $\frac{1}{2} "$ to $3 \frac{1}{2} "$ line size)
$\pm 2 \%\left(4^{\prime \prime}\right.$ and greater line size)

Repeatability and Hysteresis: $0.25 \%$ of reading

\section{LIQUID FLOW SENSORS (TOTALIZING)}

Hersey Series 400 flow meters are used to measure totalized liquid flow. The meter is a nutating disk, positive displacement type meter. An R-15 register with an SPDT reed switch is used to provide an output to the data acquisition subsystem.

The output of the reed switch is input to a Martin DR-1 Digital Ramp which counts the number of pulses and produces a zero to five volt analog signal corresponding to the pulse count.

Materials:

Accuracy:

$\begin{array}{ll}\text { Meter body } & \text { - bronze } \\ \text { Measuring chamber } & - \text { plastic } \\ \pm 1.5 \% & \end{array}$

\section{AIR FLOW SENSORS}

The Kurz 430 Series of thermal anemometers is used for the measurement of air flow. The basic sensing element is a probe which consists of a velocity sensor and a temperature sensor. The velocity. sensor is heated and operated as a constant temperature thermal anemometer which responds to a "standard" velocity (referenced to $25^{\circ} \mathrm{C}$ and $760 \mathrm{~mm} \mathrm{Hg}$ ) or mass flow by sensing the cooling effect of the air as it passes over the heated sensor. The temperature sensor compensates for variations in ambient temperature.

Since the probe measures air velocity at only one point in the cross section of the duct, it is necessary to perform a careful duct mapping to relate the probe reading to the amount of air flowing through the entire duct. This is done by dividing the duct into small areas and taking a reading at the center of each area using a portable probe. The readings are then averaged to determine the overall duct velocity. The reading at the permanently installed probe is then ratioed to this reading. This duct mapping is done for each mode.

Accuracy:

Response Time:

Repeatability: $\pm 2 \%$ of full scale over temperature range $-20^{\circ} \mathrm{C}$ to $60^{\circ} \mathrm{C}$

$\pm 5 \%$ of full scale over temperature range $-60^{\circ} \mathrm{C}$ to $250^{\circ} \mathrm{C}$

0.025 second

$0.25 \%$ full scale 
The Kent Mini-Major is used as a flow oil flow meter. The meter utilizes an oscillating piston as a positive displacement element. The oscillating piston is connected to a pulser which sends pulses to the Site Data Acquisition Subsystem for totalization.

Operating Temperature:

Flow Range:

Accuracy: $100^{\circ} \mathrm{C}(\max )$

0.6 to $48 \mathrm{gph}$

$\pm 1 \%$ of full scale

\section{FUEL GAS FLOW SENSOR}

The American AC-175 gas meter is used for the measurement of totalized fuel gas flow. The drop in pressure between the inlet and outlet of the weter is responsible for the action of the meter. The principle of measurement is positive displacement. Four chambers in the meter fill and empty in sequence. The exact vulune of compartments is known, so by counting the number of displacements the volume is measured. Sliding control valves control the entrance and exit of the gas to the compartments. The meter is temperature compensated to reference all volumetric readings to $60^{\circ} \mathrm{F}$.

Rated Capacity:

Max Working Pressure:
175 cubic $\mathrm{ft} / \mathrm{hr}$

5 psi

\section{ELECTRIC POWER SENSORS}

Ohio Semitronics Series PC5 wattmeters are used as elertric power sencoro. They utilize Hall effect devices as multipliers taking the product of the instantaneous voltage and current readings to determine the electrical power. This technique automatically takes power factor into consideration and produces a true power reading.

Power Factor Range:

Response Time:

Temperature Effect:

Accurary:

\author{
1 to 0 (lead or lag) \\ $250 \mathrm{~ms}$ \\ $1 \%$ of reading \\ $0.5 \%$ of ful1 sule
}

\section{HEAT FLUX SENSORS}

The Hy-Cal Engineering Model BI-7X heat flow sensor is used for the measurement of heat flux. The sensor consists basically of an insulating wafer, with a series of thermocouples arranged such that consecutive thermoelectric junctions fall on opposite sides of the wafer. This assembly is bonded to a heat sink to assure heat flow through the sensor. Heat is received on the exposed surface of the wafer and conducted through the heat sink. A temperature drop across the wafer is thus developed and is measured directly by each junction combination embodied along the wafer. Since the differential thermocouples are connected electrically in series, the voltages produced by each set of junctions is additive, thereby amplifying the signal directly proportional to 
the number of junctions. The temperature drop across the wafer, and thus the output signal, is directly proportional to the heating rate.

Operation Temperature:

Response Time:

Linearity:

Repeatability:

Sensitivity:

Size: $-50^{\circ}$ to $200^{\circ} \mathrm{F}$

6. seconds

$2 \%$

$0.5 \%$

$2 \mathrm{mv} / \mathrm{BTU} / \mathrm{ft}^{2}-\mathrm{hr}$

$2^{\prime \prime} \times 2$ " 
APPENDIX J

TYPICAL MONTHLY DATA 
MONTHLY REPORT: FEBRUARY 1981

SITE SUMMARY: SUMMERWOOD ASSOCIATES M

CONVENTIONAL UNITS

GENERAL SITE DATA:

INCIDENT SOLAR ENERGY

COLLECTED SOLAR ENERGY

PERCENT OF COLLECTED TO LOADS

COLLECTOR ARRAY EFFICIENCY

COLLECTOR ARRAY OPERATIONAL EFFICIENCY

AVERAGE AMBIENT TEMPERATURE

AVERAGE BUILDING TEMPERATURE

ECSS SOLAR CONVERSION EFFICIENCY

ECSS DPERATING ENERGY

ECSS PERFORMANCE FACTOR

TOTAL SYSTEM OPERATING ENERGY

TOTAL ENERGY CONSUMED

SOLAR DELIVERED/BUILDING AREA

$\stackrel{4}{1}$

$\begin{aligned} & 11.131 \text { MILLION BTU } \\ & 29841 \text { BTU/SQ.FT. } \\ & 5.023 \text { MILLION BTU } \\ & 13468 \text { BTU/SQ.FT. } \\ & 66 \text { PERCENT } \\ & 0.451 \\ & 0.585 \\ & 36 \text { DEGREES F } \\ & 61 \text { DEGREES F } \\ & 0.30 \\ & 0.228 \text { MILLION BTU } \\ & 8890 \text { BTU/SQ.FT. } \\ & 0.745 \text { MILLION BTU } \\ & 6.961 \text { MILLION BTU } \\ & \text { N.A. } \text { BTU/SQ.FT. } \\ & \text { N.A. BTU/SQ.FT. } \\ & \text { SYSTEM TOTAL } \\ & 4.738 \text { MILLION BTU } \\ & 69 \text { PERCENT } \\ & 0.000 \\ & 3.316 \text { MILLION BTU } \\ & 0.745 \text { MILLION BTU } \\ & 0.990 \text { MILLION BTU } \\ & 1.192 \text { MILLION BTU } \\ & \text { N.A. MILLION BTU } \\ & 0.588 \text { MILLION BTU } \\ & \text { N.A. MILLION BTU } \\ &\end{aligned}$

INTERPOLATED PERFORMANCE FACTORS, PERCENT OF HOURS: 8.86

\begin{tabular}{rrrr} 
HOT WATER & HEATING & COOLING & SYSTEM TOTAL \\
0.200 & 4.538 & N.A. & 4.738 MILLION BTU \\
0 & 72 & N.A. & 69 PERCENT \\
0.000 & 0.000 & N.A. & 0.000 MILION BTU \\
0.000 & 3.316 & N.A. & 3.316 MILLION \\
0.042 & 0.476 & N.A. & 0.745 MILLION BTU \\
0.200 & 0.790 & N.A. & 0.990 MILLION BTU \\
0.200 & 0.992 & N.A. & 1.192 MILLION BTU \\
N.A. & N.A. & N.A. & N.A. MILLION BTU \\
-0.042 & 0.858 & N.A. & 0.588 MILLION BTU \\
N.A. & N.A. & N.A. & N.A. MILLION BTU \\
\hline HCE FACTORS, PERCENT OF HOURS: & 8.86 &
\end{tabular}

* = UNAVAILABLE; N.A. = NOT APPLICABLE; I = INVALID; E = ESTIMATED.

REFERENCE: USER'S GUIDE TO MONTHLY PERFORMANCE REPORTS, JUNE 1980 . SOLAR/0004-80/18 READ THIS BEFORE TURNING PAGE. 
MONTHLY REPORT: FEBRUARY 1981

SITE SUMMARY: SUMMERWOOD ASSOCIATES M

CONVENTIONAL UNITS

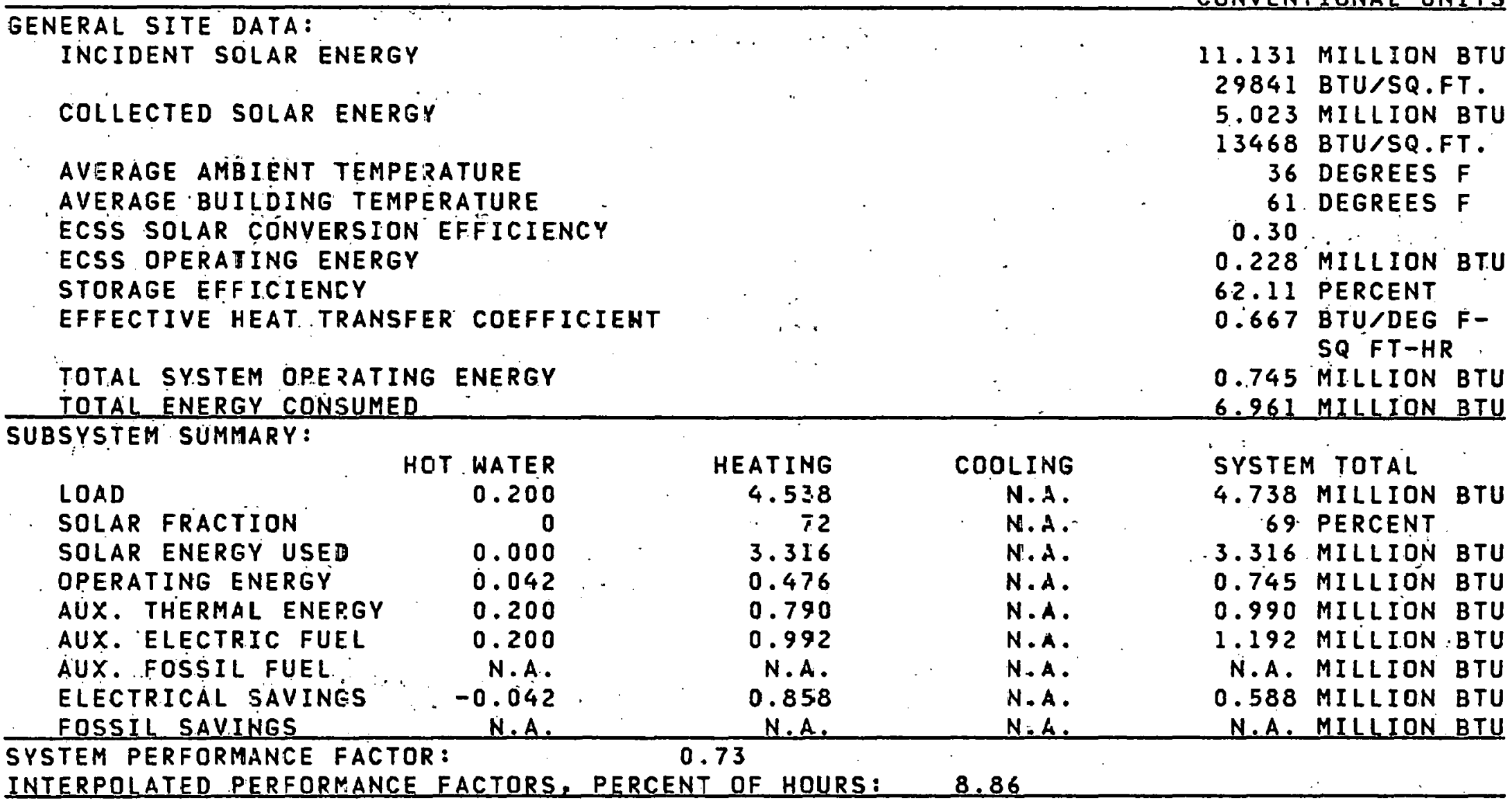

* = UNAVAILABLE; N.A. = NDT APPLICA3LE; I = INVALID; E = ESTIMATED.

REFERENCE: USER'S GUIDE TO MONTHLY PERFORMANCE REPORTS; JUNE 1980 . SOLAR/000:4-80/18

READ THIS BEFORE . TURNING PAEE. 
MONTHLY REPORT: FEBRUARY 1981

SITE SUMMARY: SUMMERWOOD ASSOCIATES M

SI UNITS

GENERAL SITE'DATA:

INCIDENT SOLAR ENERGY

COLLECTED SOLAR ENERGY

AVERAGE AMBIENT TEMPERATURE

AVERAGE BUILDING TEMPERATURE

ECSS SOLAR CONVERSION EFFICIENCY

ECSS OPERATING. ENERGY

STORAGE EFFICIENCY

EFFECTIVE HEAT TRANSFER COEFFFICIENT

TOTAL S.YSTEM OPERATING ENERGY

TOTAL ENERGY CONSUMED

SUBSYSTEM -SUMMARY:

SOLAR FRACTION
SOLAR ENERGY USED

HOT WATER

0.211

1

0.000

0.044

OPERATING ENERGY

0.211

AUX. THERMAL ENG

0.211

AUX. ELECTRIC. FUEL
AUX: FOSSIL FUEL

N.A.

ELECTRICAL SAVINGS

$-0.044$

FOSSIL SAVINGS

SYSTEM PERFORMANCE FACTOR:

INTERPOLATED PERFORMANCE FACTORS, PERCENT OF HOURS :

11.743 GIGA JOULES

$338879 \mathrm{KJ} / \mathrm{SQ} . \mathrm{M}$.

5.300 GIGA JOULES

$152939 \mathrm{KJ} / \mathrm{SQ} . M$.

2 DEGREES $C$

16 DEGREES C.

0.30

0.240 GIGA JOULES

62.11. PERCENT

3.790 W/SQ M-DEG K

0.786 GIGA JOULES

7.344 GIGA JOULES

SYSTEM TOTAL

4.999 GIGA JOULES

69 PERCENT

4.788 N.A.

N.A.

3.498

0.502

0.833

1.046

N.A.

N.A.

N.A.

N.A.

N.A.

N.A.

0,905

N.A.

3.498. GIGA JOULES

0.786 GIGA JOULES

1.044 GIGA JOULES

1.258 GIGA JOULES

N.A. GIGA JOULES

0.621 . GIGA JOULES N.A. GIGA JOULES

* = UNAVAILABLE; N.A. = NOT APPLICABLE; I = INVALID; E = ESTIMATED.

REFERENCE: USER'S GUIDE TO MONTHLY PERFORMANCE REPORTS, JUNE 1980.

SOLAR/OOO4-80/18... 
MONTHLY REPORT: SUMMERHOOD ASSOCIATES M ENERGY COLLECTION AND STORAGE SUBSYSTEM (ECSS)

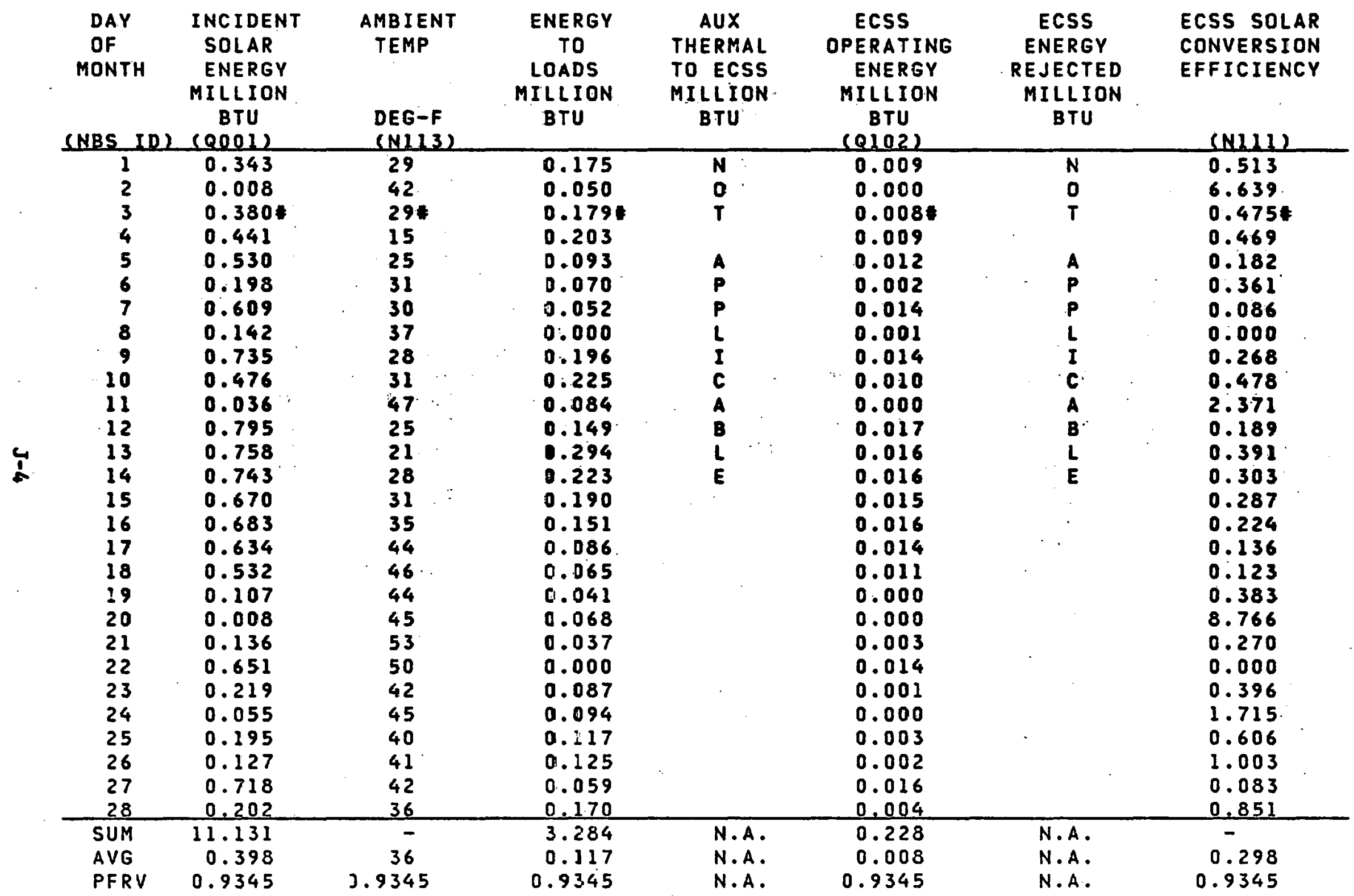

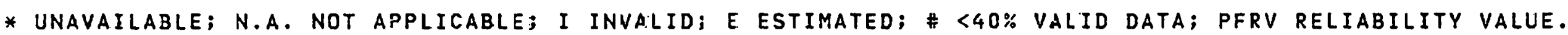


MONTHLY REPORT: SUMMERWOOD ASSOCIATES M

COLLECTOR SUBSYSTEM PERFORMANCE

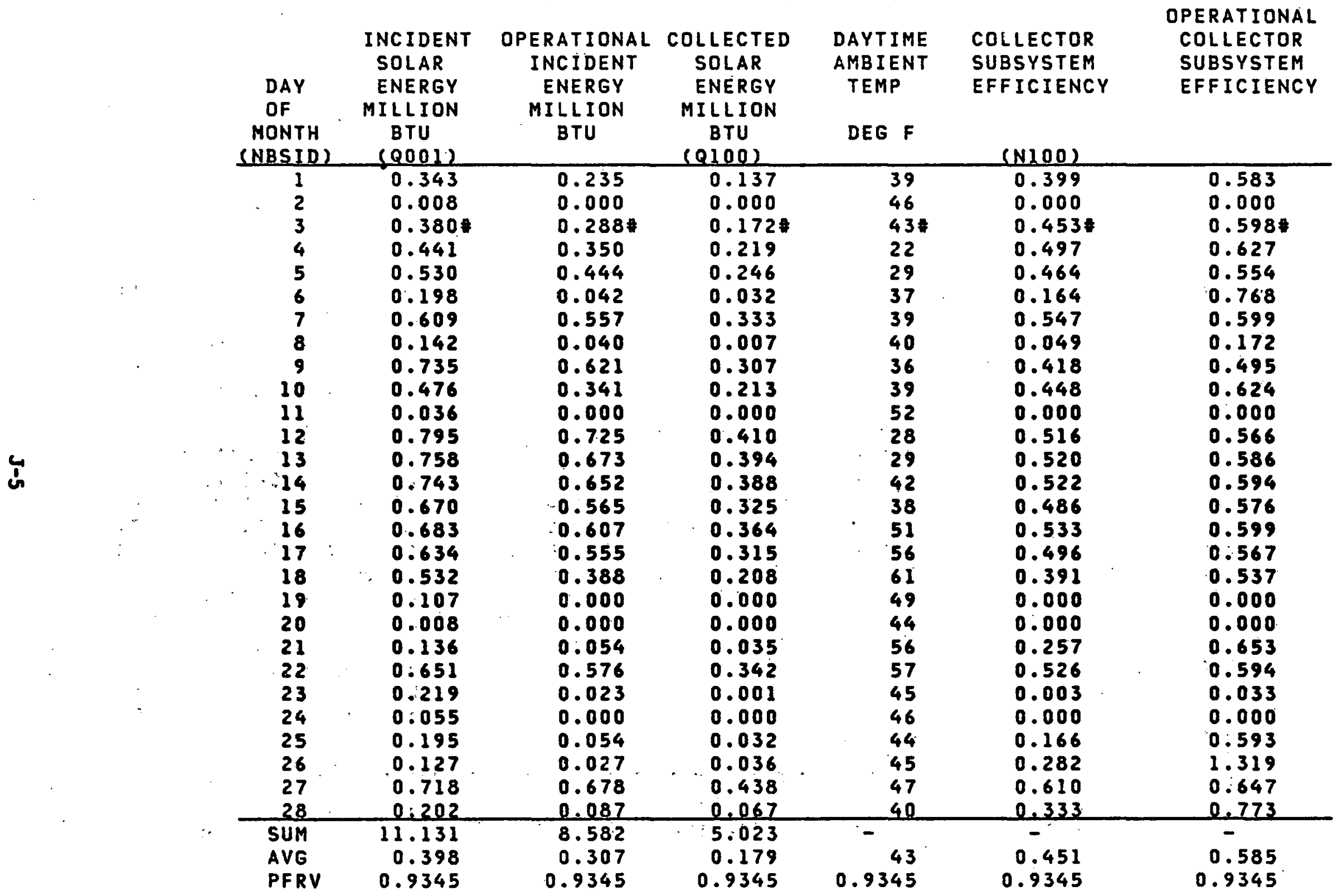

* unavailable; N.a. not applicable; I inValid; e estimated; \# <40\% VAlid data; pfrV Reliability Value. 
MONTHLY REPORT: SUMMERWOOD ASSOCIATES M

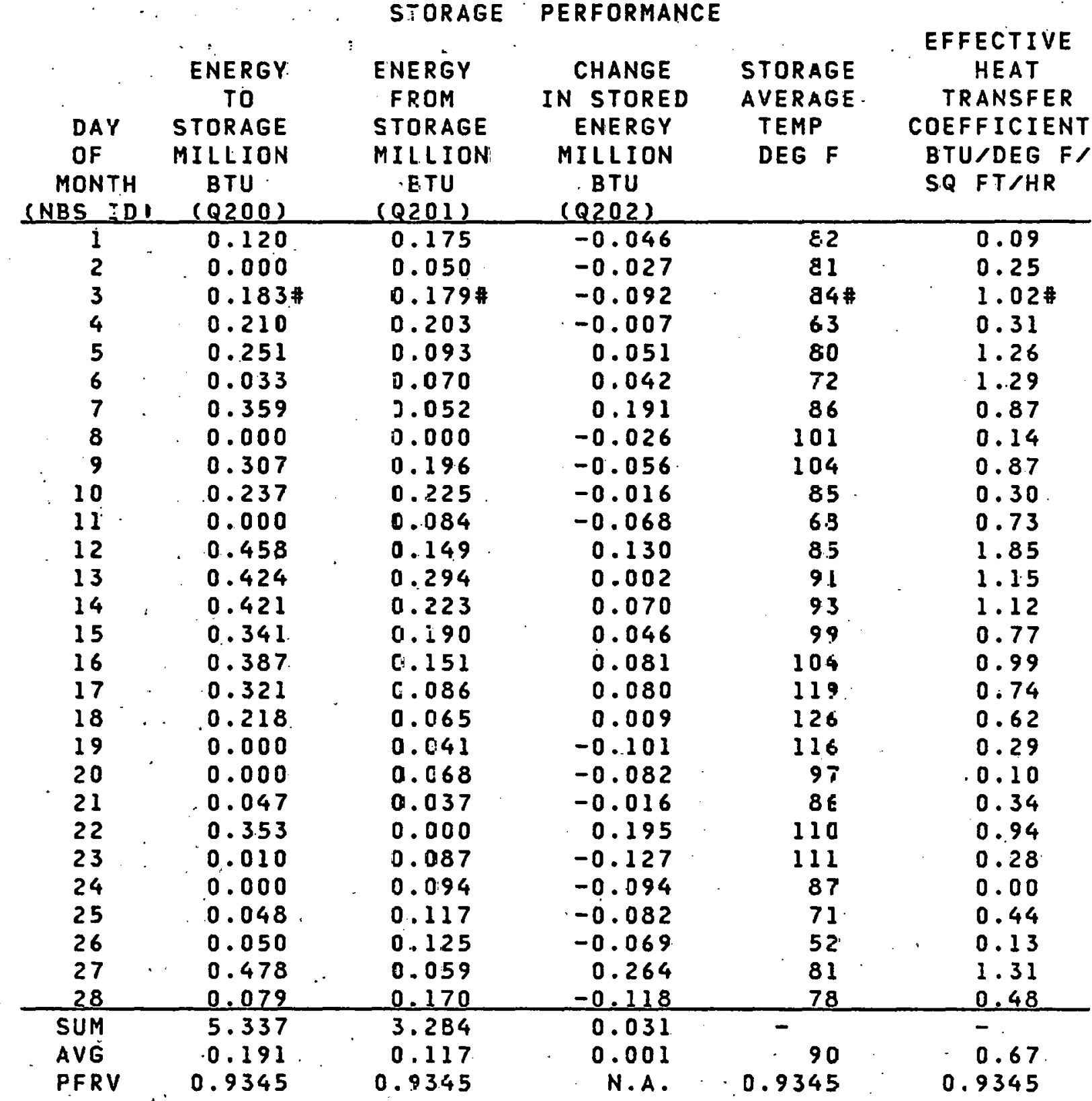

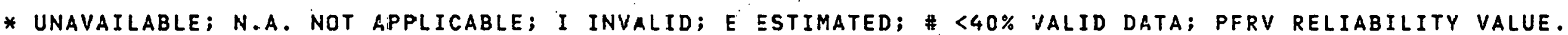


MONTHLY REPORT: SUMMERWOOD ASSOCIATES M

HOT WATER SUBSYSTEM I

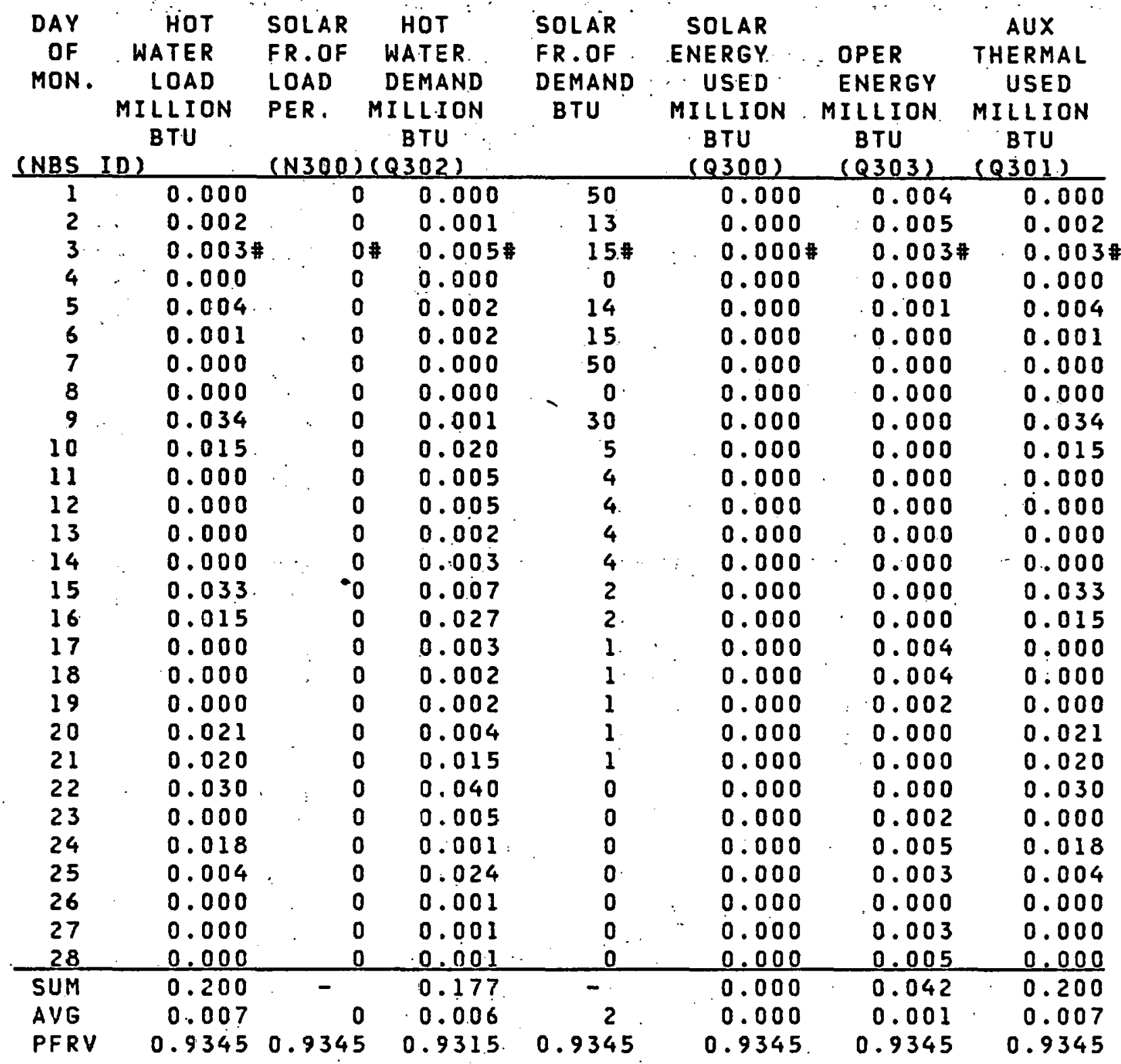

* unavailable; n.A. nOt applicable; i inValid; e estimated;

\# $\angle 40 \%$ VALID DATA; PFRV RELIABILITY VALUE. 
MONTHLY REPORT: SUMMERWOOD ASSOCIATES M

FEBRUARY 1981

HOT WATER SUBSYSTEM II

\begin{tabular}{|c|c|c|c|c|c|c|c|c|c|}
\hline \multirow{32}{*}{$\begin{array}{l}4 \\
1 \\
\infty\end{array}$} & $\begin{array}{r}\text { DAY } \\
\text { OF } \\
\text { MON. }\end{array}$ & $\begin{array}{l}\text { AUX } \\
\text { ELECT } \\
\text { FUEL } \\
\text { MILION } \\
\text { BTU } \\
(0305) \\
\end{array}$ & $\begin{array}{c}\text { AUX } \\
\text { FOSSIL } \\
\text { FUEL } \\
\text { MILLION } \\
\text { BTU } \\
(0306)\end{array}$ & $\begin{array}{l}\text { ELECT } \\
\text { ENERGY } \\
\text { SAVINGS } \\
\text { MILLION } \\
\text { BTU } \\
(0311) \\
\end{array}$ & $\begin{array}{l}\text { FOSSIL } \\
\text { ENERGY } \\
\text { SAVINGS } \\
\text { MILLION } \\
\text { BTU } \\
(0313) \\
\end{array}$ & $\begin{array}{c}\text { SUPPLY } \\
\text { WATER } \\
\text { TEMP } \\
\text { DEG } \\
F \\
(Q 305) \\
\end{array}$ & $\begin{array}{c}\text { HOT } \\
\text { HATER } \\
\text { TEMP } \\
\text { DEG } \\
F \\
(N 307) \\
\end{array}$ & $\begin{array}{c}\text { HOT } \\
\text { WATER } \\
\text { USED } \\
\text { GAL } \\
(N 308) \\
\end{array}$ & $\begin{array}{l}\text { SOLAR } \\
\text { SPECIFIC } \\
\text { OPER } \\
\text { ENERGY } \\
\text { MILLION } \\
\text { BTU }\end{array}$ \\
\hline & 1 & 0.000 & $N$ & -0.004 & $N$ & 55 & 68 & 0 & 0.004 \\
\hline & 2 & 0.002 & 0 & -0.005 & 0 & 54 & 88 & 1 & 0.005 \\
\hline & 3 & $0.003 \#$ & $T$ & $-0.003 \#$ & $T$ & $54 \%$ & $92 \#$ & $9 \#$ & $0.003 \#$ \\
\hline & 4 & 0.000 & & 0.000 & & 55 & 68 & 0 & 0.000 \\
\hline & 5 & 0.004 & A & -0.001 & A & 55 & 89 & 5 & 0.001 \\
\hline & 6 & 0.001 & $P$ & 0.000 & $\mathbf{P}$ & 55 & 93 & 3 & 0.000 \\
\hline & 7 & 0.000 & $\mathbf{P}$ & 0.000 & $\mathbf{P}$ & 53 & 59 & 0 & 0.000 \\
\hline & 8 & 0.000 & $\mathbf{L}$ & 0.000 & $L$ & 53 & 59 & 0 & 0.000 \\
\hline & 9 & 0.034 & I & 0.000 & I & 52 & 65 & 9 & 0.000 \\
\hline & 10 & 0.015 & c & 0.000 & C & 50 & 133 & 30 & 0.000 \\
\hline & 11 & 0.000 & A & 0.000 & A & 51 & 111 & 11 & 0.000 \\
\hline & 12 & 0.000 & B & 0.000 & B & 52 & 86 & 18 & 0.000 \\
\hline & 13 & 0.000 & $L$ & 0.000 & L & 52 & 76 & 10 & 0.000 \\
\hline & 14 & 0.000 & $E$ & 0.000 & E & 52 & 71 & 16 & 0.000 \\
\hline & 15 & 0.033 & & 0.000 & & 52 & 107 & 14 & 0.000 \\
\hline & 16 & 0.015 & & 0.000 & & 53 & 136 & 38 & 0.000 \\
\hline & 17 & 0.000 & & -0.004 & & 5.3 & 110 & 6 & 0.004 \\
\hline & 18 & 0.000 & & -0.004 & & 54 & 91 & 6 & 0.004 \\
\hline & 19 & 0.000 & & -0.002 & & 55 & 79 & 11 & 0.002 \\
\hline & 20 & 0.021 & & 0.000 & & 53 & 79 & 19 & 0.000 \\
\hline & 21 & 0.020 & & 0.000 & & 53 & 137 & 21 & 0.000 \\
\hline & 22 & 0.030 & & 0.000 & & 51 & 135 & 58 & 0.000 \\
\hline & $2 \cdot 3$ & 0.000 & & -0.002 & & 53 & 114 & 10 & 0.002 \\
\hline & 24 & 0.018 & & -0.005 & & 56 & 84 & 2 & 0.005 \\
\hline & 25 & 0.004 & & -0.003 & & 52 & 124 & 40 & 0.003 \\
\hline & 26 & 0.000 & & 0.000 & & 52 & 77 & 6 & 0.000 \\
\hline & 27 & 0.000 & & -0.003 & & 54 & 71 & 5 & 0.003 \\
\hline & 28 & 0.000 & & -0.005 & & 54 & 70 & 4 & 0.005 \\
\hline & SUM & 0.200 & N.A. & -0.042 & N.A. & - & - & 352 & 0.042 \\
\hline & AVG & 0.007 & N.A. & -0.001 & N.A. & 52 & 111 & 13 & 0.001 \\
\hline & PFRV & 0.9345 & N.A. & 0.9345 & N.A. & 0.9315 & 0.9315 & 0.9315 & 0.9345 \\
\hline & 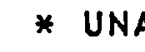 & I LABLE; & NOT & A.PPL ICA & I I & LID; $E$ & ESTIMAT & & \\
\hline & $\#<4$ & VALID & PFRV & ELIABI & YY VALI & & & & \\
\hline
\end{tabular}


MONTHLY REPORT: SUMMERWOOD ASSOCIATES M

FEBRUARY 1981

SPACE HEATING SUBSYSTEM I

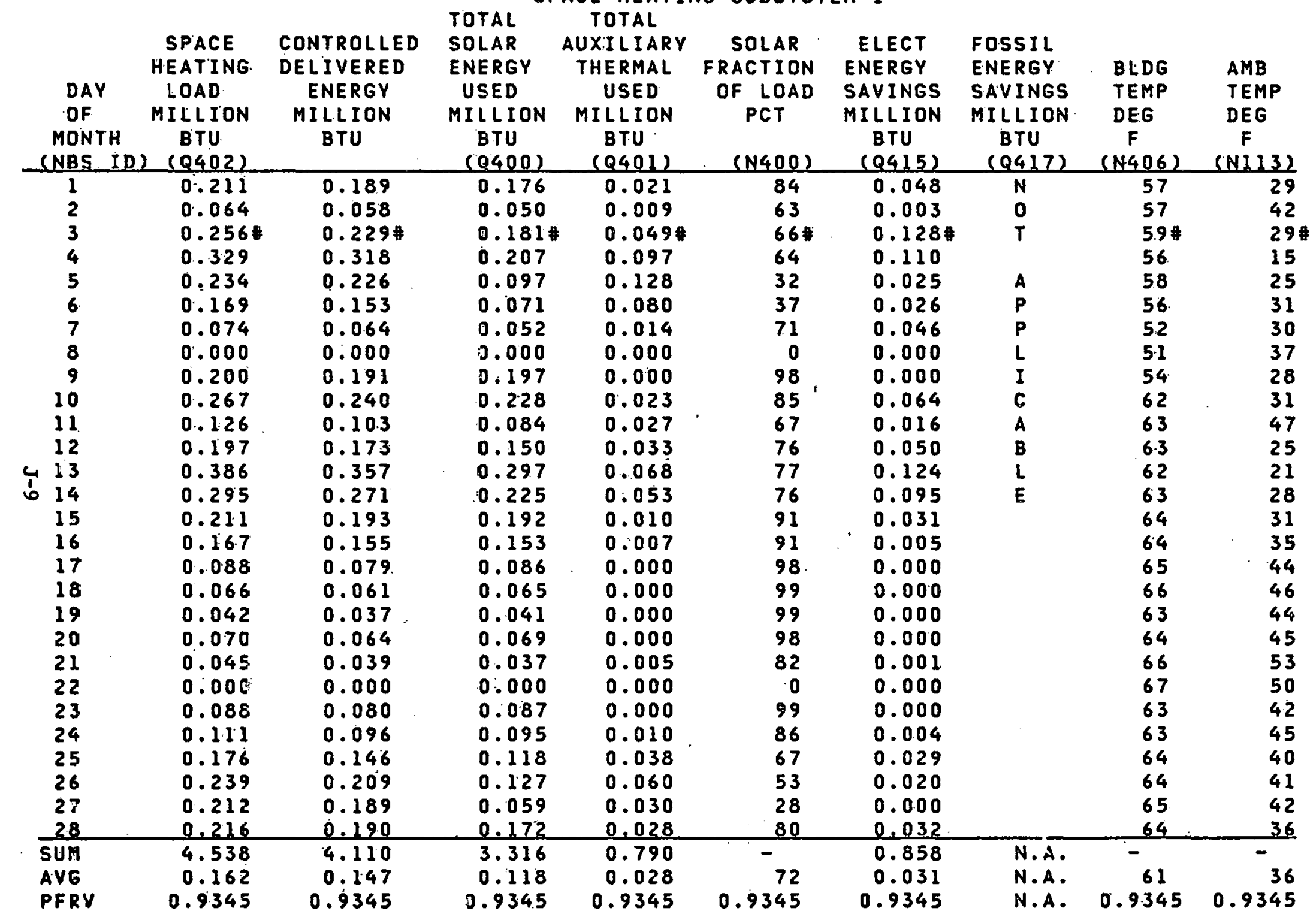

* unavailable; N.a. not applicable; I inValid; e estimated; * <40\% Valid data; pfrV Reliability Value. 
SPACE HEATING SUBSYSTEM II

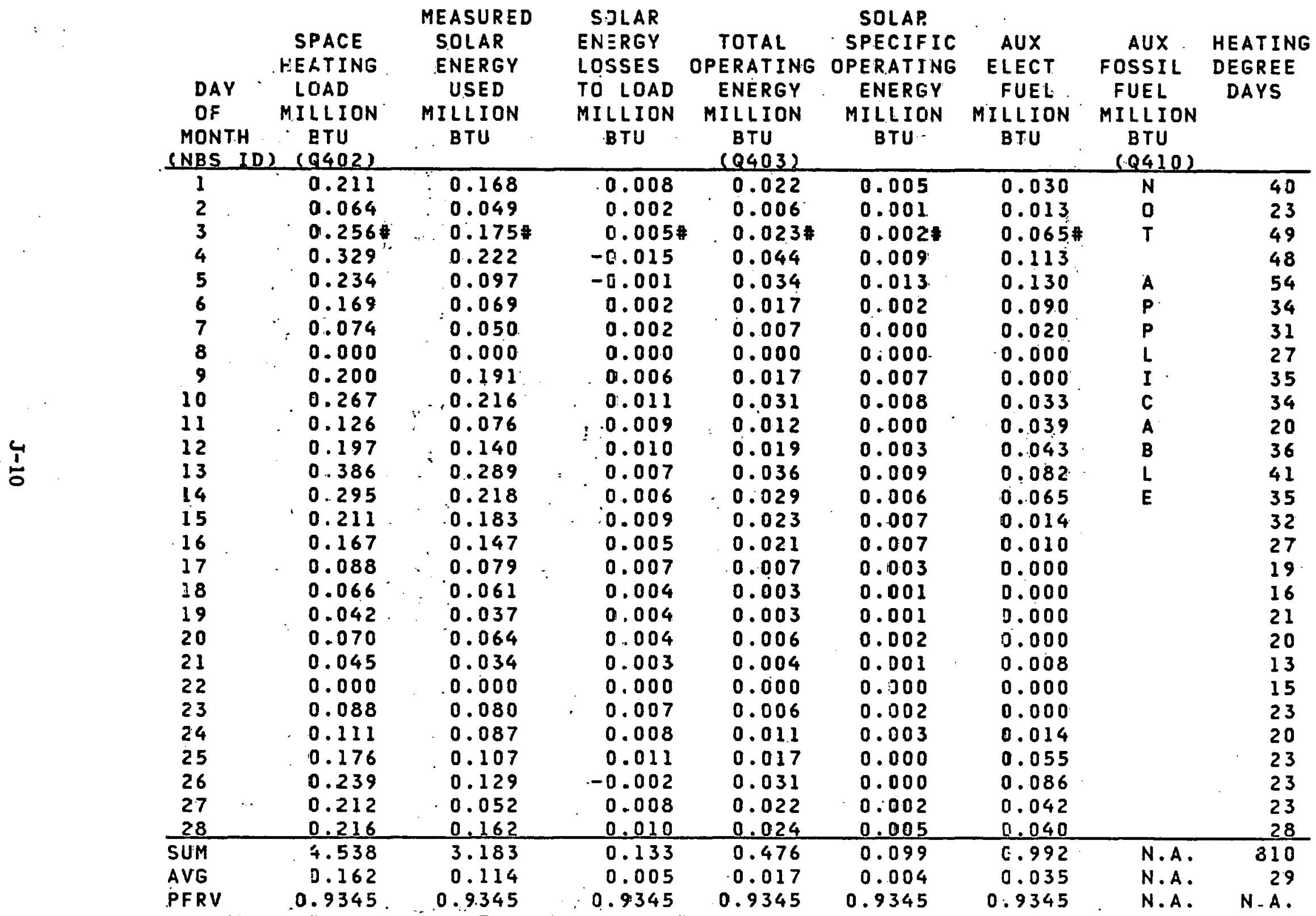

* unavailabli; N. A. NOT applicable; I INVALID; E ESTIMATED;

\# <40\% VALID DATA;. PFRV RELIABILITY VALUE. 
MONTHLY REPORT: SUMMERWOOD ASSOCIATES M

THERMODYNAMIC CONVERSION EQUIPMENT

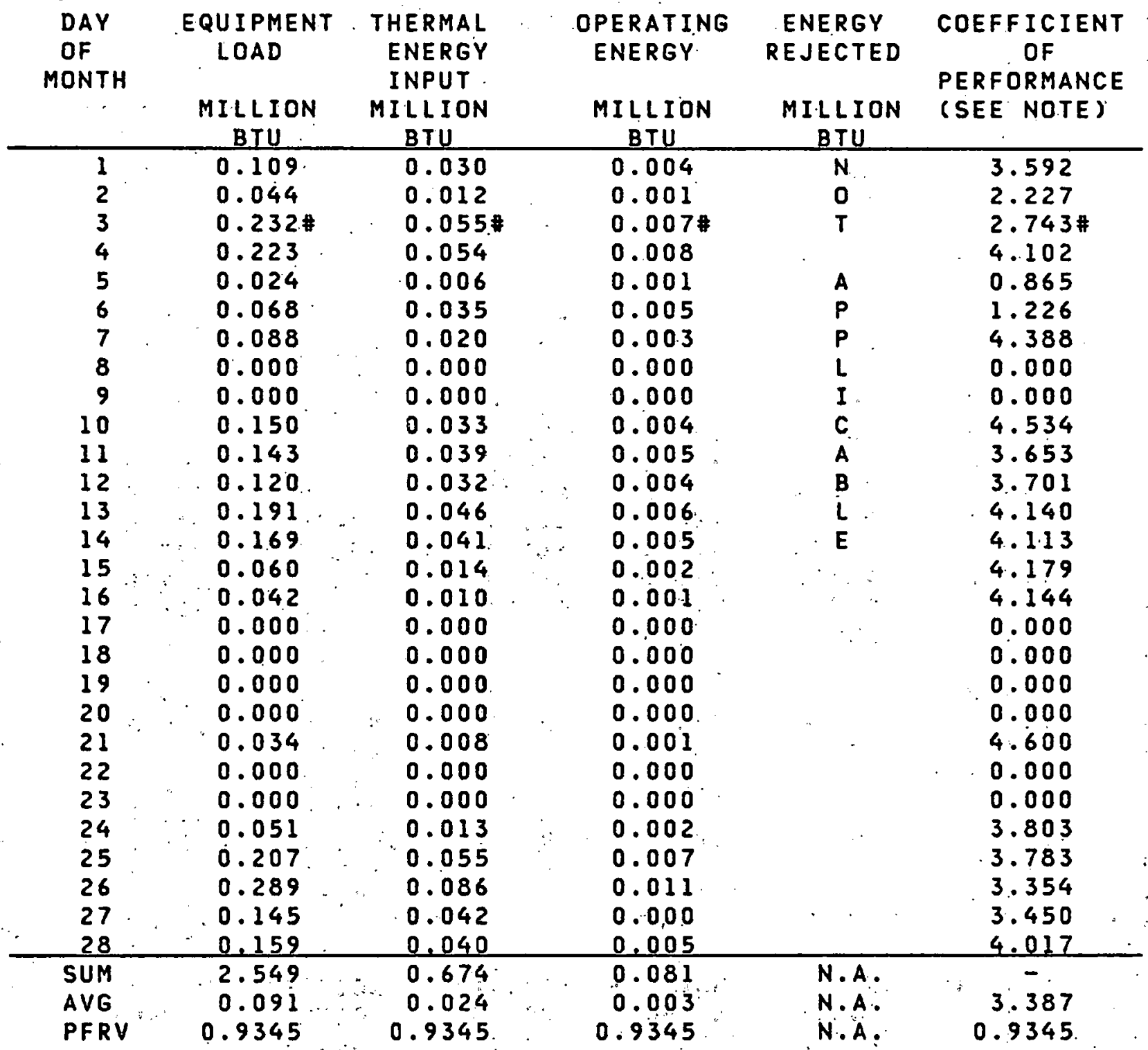

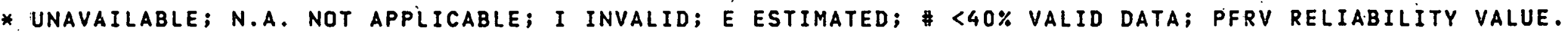




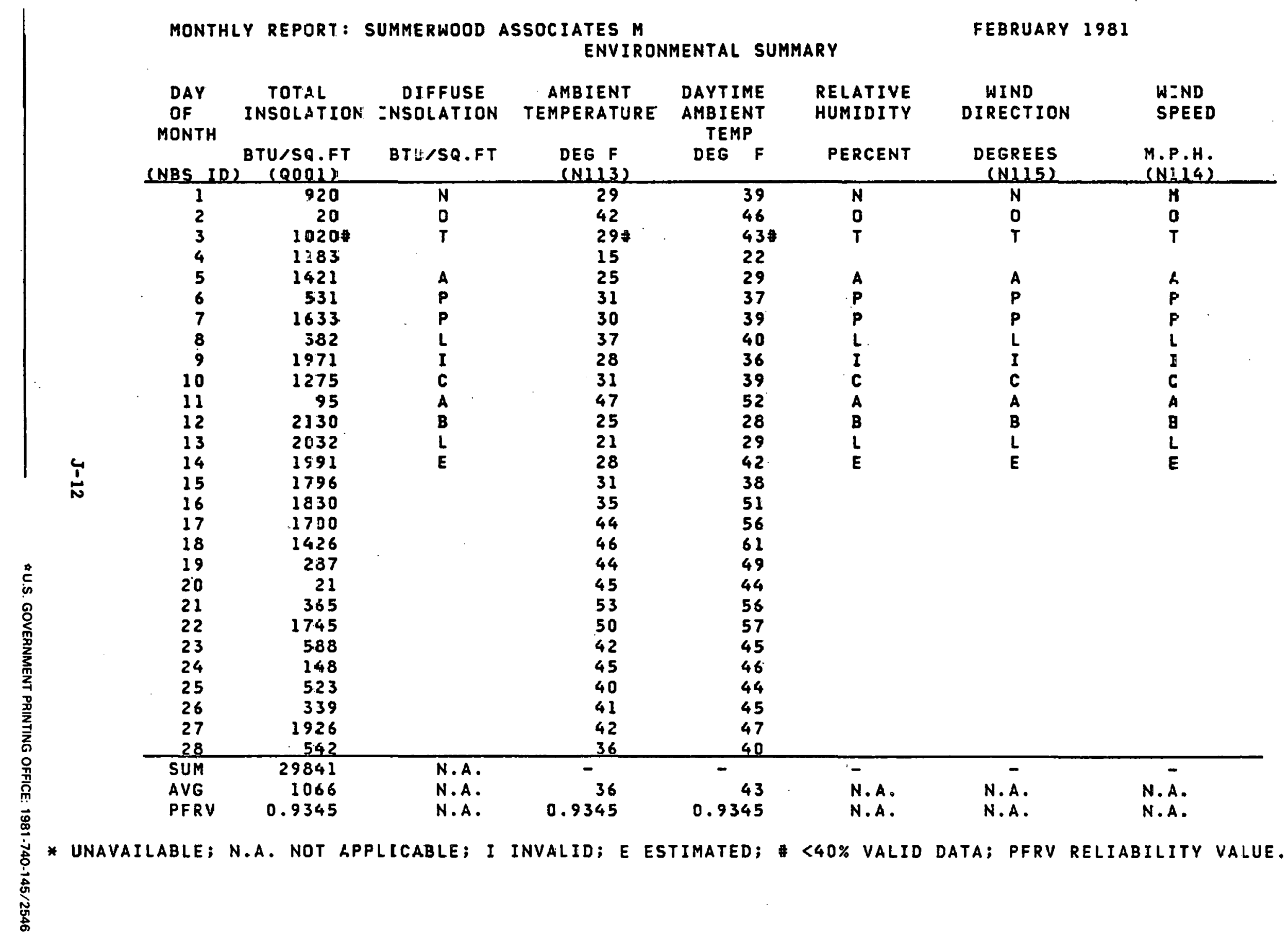

